Culura,

podere

dimheiro

na gestão

das cidades

otilia Arrantes 


\section{Cultura, poder e dinheiro na gestão das cidades}


A coleção é organizada em sete categorias e três subcoleções, com diferentes tipologias documentais e formatos de arquivos:

Categorias: Filosofia; Política; Estética; Arquitetura e Cidades; Artes Plásticas; Crítica da Cultura e Trajetórias. Cada categoria adota uma cor específica aplicada na capa do e-book.

\section{Subcoleções:}

E-books: livros, capítulos, prefácios, artigos e entrevistas (em formatos PDF, EPUB e MOBI/Kindle) - com obras em português, inglês, espanhol, italiano e francês.

Documentos: matérias de jornal, fotos e documentos históricos (em formatos

PDF e JPEG)

Mídia: vídeos ou áudios de palestras, aulas e debates (em formatos MP3 e MP4) associados a um canal da coleção no YouTube.

Coordenação editorial: Pedro Fiori Arantes

Projeto Gráfico: Paula Astiz

DADOS INTERNACIONAIS DE CATALOGAÇÃO NA PUBLICAÇÃO (CIP) (CÂMARA BRASILEIRA DO LIVRO, SP, BRASIL)

Arantes, Otília Beatriz Fiori, 1940

Dinheiro, poder e cultura na gestão da cidade [recurso eletrônico]/

Otília Beatriz Fiori Arantes. -- São Paulo : [s.n], 2021.

ePUB. - (Coleção sentimento da dialética / coordenação Pedro

Fiori Arantes)

(Coleção sentimento da dialética / coordenação Pedro Fiori

Arantes)

ISBN 978-65-00-25768-7

1. Espaços públicos. 2. Planejamento urbano. 3. Cidades e vilas. 4 Política urbana. I. Arantes, Pedro Fiori, 1974-. II. Título. III. Série.

CDD 307.76

Elaborado por Cristiane de Melo Shirayama - CRB 8/7610

DOI: http://doi.org/10.34024/9786500257687

\section{(c) $(1) \Theta \Theta$}

Esta obra tem licença Creative Commons internacional 4.0

http://creativecommons.org/licenses/by-nc-nd/4.0/

\section{Capítulos publicados originalmente como:}

Arantes, Otília. "A Ideologia do "Lugar Público" na Arquitetura Contemporânea (Um Roteiro)". Em O Lugar da Arquitetura depois dos Modernos. São Paulo: Edusp, 1993. Arantes, Otilia. "Cultura da cidade, animação sem frase". Em Urbanismo em fim de linha, São Paulo: Edusp, 1997.

Arantes, Otília. "Uma estratégia fatal: A cultura nas novas gestões urbanas". Em Arantes, Vainer, Maricato, A cidade do pensamento único. Petrópolis: Ed. Vozes, 2000

\section{Sentimento da Dialética}

UM ENCONTRO COM A OBRA DE OTIILIA E PAULO ARANTES

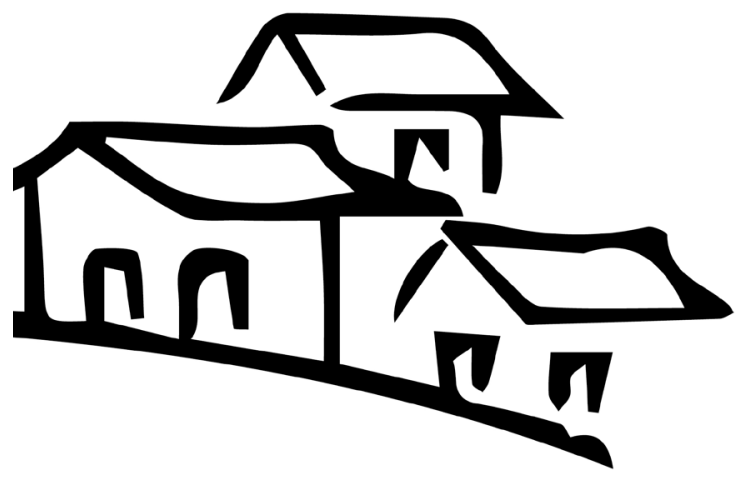




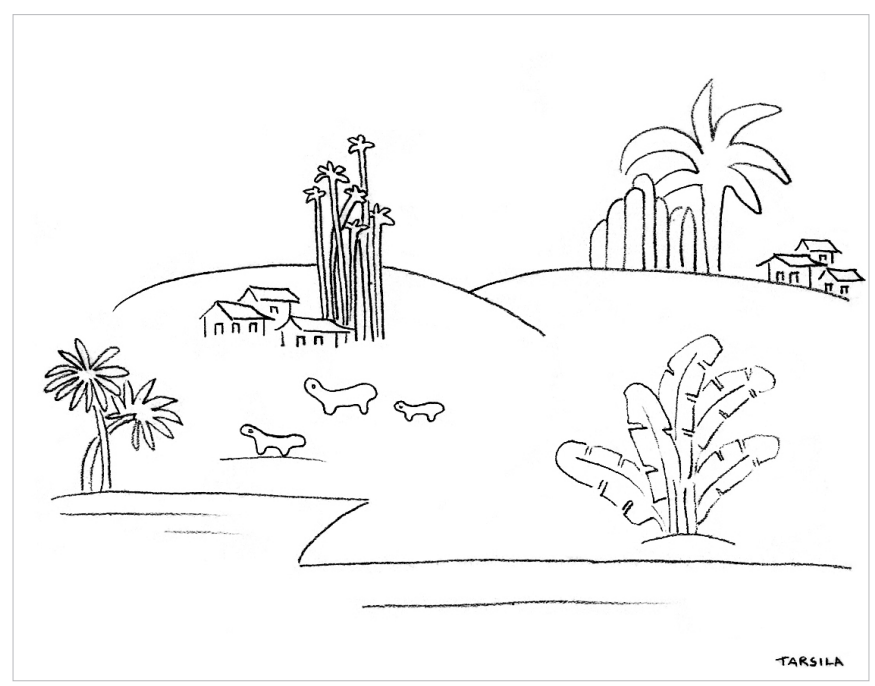

Tarsila do Amaral. Paisagem antropofágica - I, 1929 c - lápis s/ papel, 18,0 x 22,9 cm. Coleção Mário de Andrade. Coleção de Artes Visuais do Instituto de Estudos Brasileiros USP. Reprodução gentilmente cedida pela família e IEB USP.

O novo tempo do mundo exige dos intelectuais responsabilidades que lhes são intrínsecas: a de tornar a força das ideias parte do movimento de entendimento e transformação do mundo. Os filósofos Otília Beatriz Fiori Arantes e Paulo Eduardo Arantes cumprem, juntos, há mais de 50 anos, a tarefa da crítica como intelectuais públicos atuantes, transitando entre diversas áreas das humanidades e da cultura, em diferentes audiências e espaços de formação. A coleção Sentimento da Dialética é um lugar de encontro com a obra de Otília e Paulo Arantes e reafirma o sentido coletivo da sua produção intelectual, reunida e editada em livros digitais gratuitos. É um encontro da sua obra com um público cada vez mais amplo, plural e popular, formado por estudantes e novos intelectuais e ativistas brasileiros. É também um encontro da sua obra com o movimento contemporâneo em defesa do conhecimento livre e desmercantilizado, na produção do comum e de um outro mundo possível. Aldo Rossi, Desenho para o Teatro do Mundo, Bienal de Veneza, 1979. 

arquitetura contemporânea (um roteiro)

Cultura da cidade, animação sem frase

Uma estratégia fatal, a cultura nas novas gestões urbanas 


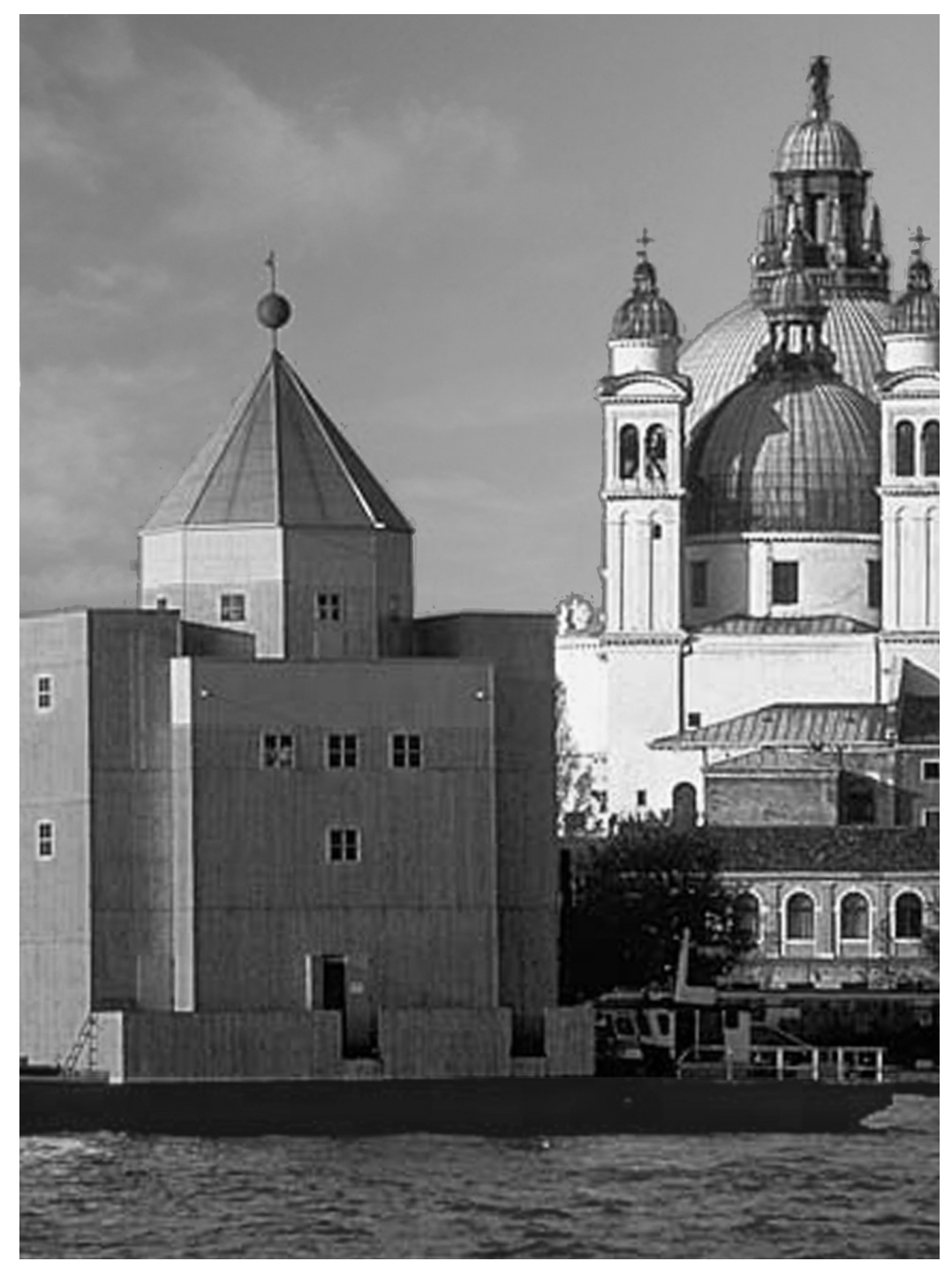

Aldo Rossi, Teatro do Mundo, Bienal de Veneza, 1979.

\section{A ideologia do "lugar público" na arquitetura contemporânea (um roteiro)'}

No intuito de devolver a cidade moderna à coletividade expropriada ao longo do processo de constituição das grandes aglomerações urbanas contemporâneas, arquitetos e urbanistas entregaram-se, particularmente a partir de meados dos anos 60, a uma verdadeira obsessão pelo lugar público, em princípio o antídoto mais indicado para a patologia da cidade funcional. Esse clima de opinião remonta na verdade às primeiras secessões do Movimento Moderno no pós-guerra, mas só nas duas últimas décadas tomou uma feição de lugar comum ideológico, ponto de encontro - bem peneirado - entre velhos argumentos conservadores e outros tantos colhidos na voga neoiluminista mais recente, ela mesmo menos uma resposta do que uma caixa de ressonância das sucessivas metamorfoses da esfera pública no capitalismo avançado. $O$ terreno não poderia ser mais escorregadio. Sirvam de amostra duas referências, às quais voltarei mais adiante.

A primeira delas vem de um teórico da Escola de Veneza que, como se sabe, desde pelo menos o fim dos anos 60 , está empenhada numa das revisões mais abrangentes

1. Redigido em 1988, este roteiro viria a balizar meus cursos na pós-graduação da FAU USP nos dois anos subsequentes. Publicado originalmente em O Lugar da Arquitetura depois dos Modernos, São Paulo: EDUSP, 1993. 
e nuançadas da utopia moderna do Plano. Nessa direção, depois de passar em revista as principais implicações da sociologia alemã da cidade desde os tempos de Tönnies e Simmel, Massimo Cacciari chama a atenção para um desdobramento inesperado daquelas ideias que nortearam o primeiro grande confronto do pensamento sociológico em formação com a alienação moderna: nada mais falso e desafinado, denuncia, do que reencontrar um por um os antigos ideais da comunidade - a Gemeinschaft orgânica que Tönnies contrapunha às relações anônimas e mecânicas da sociedade - entre os muitos argumentos atuais contra a Metrópole, condenada não por dar forma à supremacia do Capital, mas por encarnar o "intelecto abstrato", ou se se preferir, a "razão instrumental". ${ }^{2}$ Segundo Cacciari, uma das expressões mais acabadas do mito reacionário da polis está se convertendo num dos temas prediletos das teorias críticas da Metrópole (os exemplos que cita são O fetiche urbano de Mitscherlich e Ideologia da arquitetura de Horn).

No outro extremo, um dos atuais promotores da ressurreição do "homem público", tal como o conheceram os séculos XVII e XVIII antes da entrada em cena do sujeito burguês - uma espécie de apogeu do Iluminismo, paraíso da urbanidade logo perdida; refiro-me às críticas conhecidas do sociólogo americano Richard Sennet à febre comunitária da sociedade contemporânea. Embora empregue às vezes a palavra alemã, a Comunidade visada por Sennet não é mais aquela a que se referia Cacciari. Em lugar de uma reminiscência do mundo tradicional erigida em ins-

2. Cacciari, "Dialetica de lo negativo en las epocas de la Metropole", in Tafuri, Cacciari e Dal Co. De la vanguardia a la metropole, Barcelona: Gustavo Gili, 1972 (pp. 79 a 151); p. 95. tância crítica dos traumas da modernização - aliás um equívoco procedente e corrente, pois o processo do capitalismo também se fez em nome da tradição que ele erradicou -, trata-se de uma atrofia da hora presente: os novos ideais da comunidade exprimem uma fobia ultramoderna, o temor da vida civil ativa, contaminada por sua vez, na explicação do autor, pelo vírus da "intimidade". A tirania desta se manifestando, entre outros sintomas, pela promoção exclusiva de relações sociais fundadas nos arcanos da personalidade, da partilha de emoções "profundas", "autênticas", etc. Em suma, estaríamos em presença de uma psicologização da vida social tão alastrada que se espelharia inclusive nas fórmulas descritivas do próprio autor, nisto muito próximo das análises de Christopher Lash a respeito do triunfo do "narcisismo" na sociedade americana atual.

Psicologismo à parte, interessa-nos salientar o vínculo estabelecido por Sennet entre a "idolatria intimista" da comunidade e a degradação simultânea da arquitetura urbana e da vida em público: como era de se esperar, depois de um século de crítica à grande cidade, a luta contra a impessoalidade moderna, em nome agora da lógica emocional da comunidade, se volta contra a metrópole, buscando na "vizinhança" dos corações transparentes um contacto imediato, protegido entretanto do confronto político público pela Nova Construção. Por isso a difusão desta última acelera o "declínio do homem público". ${ }^{3}$ Sem dúvida inverteram-se as posições, se pensarmos no amálgama assinalado acima. Persiste, no entanto, a ilusão ilustrada complementar: valendo-se da dupla raiz histórica da "urbanidade", Sennet ainda sonha com o renascimento do ho-

3. Título do livro de Sennet ao qual estamos nos referindo. 
mem público mediante a reinvenção da cidade - por certo longe tanto da falsa transparência do plate glass quanto do fetiche compensatório da neighbourhood, porém, até certo ponto, de volta ao beco modernista. Arquitetos e urbanistas passaram então a criar — ou simplesmente preservar - fatos urbanos, lugares destinados em princípio a reativar formas da vida social, focos em condições de aglutinar um sem número de objetos arquitetônicos desconexos em torno de um espaço que se apresentasse como "coisa pública". Nas condições adversas evocadas há pouco, redescobriram a lição de Camillo Sitte, enfática sobretudo na crítica da reurbanização da Ringstrasse. ${ }^{4}$ Obviamente não se tratava mais de reinventar a praça e sua constelação de pontos de apoio, ao mesmo tempo obra de arte e palco de referências, como queria Camillo Sitte no fim do século passado. Alegava-se, ao contrário, que a inspiração desse reencontro com os fatos urbanos "memoráveis" não teria parte com a nostalgia revivalista, que o enraizamento histórico propiciado por ele expressaria antes a abertura de uma nova dimensão prospectiva. De volta então ao futuro dos modernos e sua concepção totalizante do projeto? Também não: Gregotti e Casabella, por exemplo, adotarão uma estratégia de intervenção baseada em "deslocamentos mínimos", "modificações contínuas" que no limite desmontariam a utopia do infinito atual característica do Movimento Moderno. ${ }^{5}$ Noutro registro teórico, a Collage City de Collin Rowe, por exemplo, invocará o mesmo princípio de indeterminação para recusar a cidade axial dos modernos e decompor a utopia — trata-

4. Sitte, Camillo. Construcción de Ciudades según principios artisticos, trad. da 5a. ed. alemã, Barcelona: Ed. Canosa, s/d.

5. Casabella n. 498/9, Milão, 1984; cf. especialmente pp. 14/15. da agora como imagem - em fragmentos reanimados por um procedimento de colagem urbana. ${ }^{6} \mathrm{E}$ assim por diante. Precisaríamos, como se pode perceber, recompor as peças de um enorme girar em falso que obseda arquitetos e urbanistas: muitos retalhos doutrinários aparentemente disparatados, mas sobretudo momentos do pensamento arquitetônico desentranhados da própria atividade projetual e no fundo, como sempre, o mutável campo de forças que lhes dê sentido, no caso, as novas polarizações do público e do privado numa era de reação conservadora e apologia direta do capitalismo.

\section{A "agorafobia" moderna}

A partir dos anos 50, conforme decrescia a confiança no programa urbano dos CIAM, o arquiteto austríaco Camillo Sitte, até então tido como um paladino da urbanística antimoderna, voltou a ser lido e apreciado na sua justa medida. No final do século XIX, em meio às grandes reformas urbanas, seu livro sobre A construção das Cidades segundo princípios artísticos surpreendera arquitetos e urbanistas afeitos às modernizações implacáveis, ao retomar as lições do passado, especialmente quanto à ordenação das praças, com o intuito de "estabelecer um conjunto de regras" que pudesse produzir "efeitos análogos" nas cidades modernas. ${ }^{7}$ O sucesso imediato que levou o livro a várias reedições foi entretanto interrompido com a hegemonia do Movimento Moderno que o via como um

6. Rowe e Koetter . Ciudad Collage, Barcelona: GG, 1981; especialmente pp. $144 / 145$

7. Cf. Prefácio, de 7 de maio de 1889. 
defensor das cidades antigas, suas praças irregulares e seus "caminhos de burro" - numa expressão utilizada por Le Corbusier para desqualificar as ruelas medievais (presumidamente tidas como paradigmáticas por Sitte), em nome da maior racionalidade dos novos traçados urbanos. ${ }^{8} \mathrm{Na}$ verdade, longe de ser um revivalista, o que Camillo Sitte lastimava no urbanismo do século XIX era a perda do sentido estético e social das praças - e certamente multiplicaria suas críticas caso tivesse conhecido os grandes centros urbanos do século XX.

Note-se que esta preocupação com a praça não desempenha por acaso um papel central no argumento do livro. Para o autor, uma praça é antes de tudo um lugar público, no sentido forte desta última palavra. Daí o destaque conferido ao exemplo do Forum Romano, jamais proposto aliás como modelo a ser repetido: o que lhe interessava era chamar a atenção para o caráter público da vida que ali transcorria, contrapondo esta manifestação arquitetônica da existência civil na antiguidade ao suporte idílico comunitário da cidade medieval. ${ }^{9}$ As digressões históricas do livro não têm portanto propósito restaurador, visam mais salientar certas constantes na organização espacial urbana que não deveriam ser esquecidas pelos novos projetos de reurbanização - como foram, por exemplo, no Ring de Viena. ${ }^{10}$

8. Le Corbusier. L'urbanisme, 1922. O equívoco se deve em parte a uma tradução francesa do início do século, ao substituir exemplos originais por outros extraídos da história urbana da França e em especial por praças medievais.

9. De Witte. "L'éloge de la place”, in La ville inquiète, Paris: Gallimard, 1987 (pp. 151 a 177); especialmente p. 155.

10. Embora um historiador conhecido como Schorske, em seu livro Vienne-fin-de-siècle - seguindo a tradição crítica - enfatize antes de tudo o lado passadista da posição de Camillo Sitte, é obrigado a reconhecer que se tratava de uma proposta de cidade na medida do homem, e que suas reinvindicações psicológicas e sociais eram comuns a muitos contemporâneos do autor.
As belas praças do passado não satisfariam apenas uma exigência estética; Camillo Sitte estava convencido de que aquela disposição esteticamente exigente era antes de tudo decorrência do intuito de circunscrever um espaço próprio à vida pública. Como observado por De Witte, a quase obsessão de Sitte com a praça não traduz apenas a adesão natural do esteta a uma verdadeira obra de arte - como considerava as praças antigas e julgava que deveriam ser as modernas, ainda que devessem renunciar a um sem número de motivos artísticos irrepetíveis numa vida tão "matemática" como a nossa - , mas sobretudo a atração pelo enigma resolvido de um espaço capaz de conjugar interioridade e exterioridade, ao mesmo tempo aberto e fechado. - Espaço público, mas arrumado como se fora um ambiente interno de uma casa ou, numa comparação do próprio Sitte, como uma sala hipetra para reuniões. ${ }^{11}$ Em contrapartida, nas cidades reurbanizadas do século XIX, as praças estariam sendo substituídas por espaços pura e simplesmente exteriores, vazios residuais, impróprios para o uso coletivo. Quase sempre superdimensionados, tais espaços desérticos (por mais povoados que se apresentem) seriam responsáveis por uma nova "doença nervosa", característica dos tempos modernos, provocada em larga medida pela ausência de pontos de referência, síndrome que Sitte passou a chamar de "agorafobia".

Já as praças antigas - quer dizer, da Antiguidade à Idade Barroca - , com sua multiplicidade de formas complexas, foram concebidas para promover a reunião da coletividade local; era na praça que ocorriam os acontecimentos mais importantes da vida em comum, ela era o lugar urbano por excelência. Por isso, acreditava Sitte, uma

11. Cf. trad. Gustavo Gili (1980), p. 6 a 10 (162 a 166) sobre Forum Romano. 
cidade sem praça não mereceria tal designação. Uma praça "antiga" não se resumia a um conjunto de monumentos ou de prédios oficiais, ela era uma espécie de imagem pública em que o habitante se reconhecia enquanto homem livre. ${ }^{12}$ Algo difícil de imaginar num contexto moderno. Fosse a praça o lugar de um jogo que atraísse uma pequena multidão de participantes e espectadores, ou então, de alguma atividade política, era ela o "coração da cidade": e não por acaso a partir dos anos 50 os arquitetos começaram a adotar esta expressão de Camillo Sitte, no intuito de criar lugares que revitalizassem as cidades destruídas pela guerra ou pelo urbanismo predatório moderno.

Desnecessário lembrar que Sitte não era um teórico da modernização - sabia, no entanto, que o processo era inelutável, que muitas formas antigas já não tinham mais significação e que um artista à altura de sua vocação não podia se deixar levar pelo sentimentalismo. Por isso descrevia com realismo os sintomas urbanos dessa transição irremediável. Assim, a agorafobia respondia a uma mudança radical nos rumos da vida na cidade, que refluíra dos espaços públicos para os interiores, para os recintos fechados. Em consequência, seus novos habitantes iam se transformando no que ele com ironia chama "modernos pantouflards". Política parlamentar, imprensa, entrega a domicílio, água encanada, etc., tudo concorre para esse enclausuramento: nem termas, nem colunatas, nem praças do mercado, nem fontes, etc., podem mais (caso fossem de novo ressuscitadas) impedir que a vida popular continue se retirando da praça pública, tornando cada vez mais problemático algo como uma "urbanização artística”. Edifícios sempre mais altos e extensos dificilmente

12. De Witte. op. cit. poderão ser dispostos esteticamente, uma vez que tudo tende à repetição, restringindo cada vez mais a possibilidade da concepção esteticamente original. Daí o aparente paradoxo do gosto moderno: todos admiram o Palácio Ducal em Veneza ou o Capitólio de Roma, mas ninguém cogitaria projetar algo parecido. É que a modernidade bem compreendida tornou-se um convite à modéstia — diz Sitte - , outra maneira de lembrar que doravante é preciso sujeitar a tradição às condições técnicas do tempo. ${ }^{13} \mathrm{Em}$ consequência, quando projeta, como no caso do plano de reurbanização para a Ringstrasse com que conclui seu livro, sempre leva em conta os novos usos da cidade, porém não consegue imaginar um espaço urbano que abdique da dimensão artística e suas características diferenciadas, pelo menos em condições de contrariar a tendência da cidade moderna à monotonia. ${ }^{14}$

Uma das muitas observações de Camillo Sitte acerca dos sintomas da agorafobia concerne o novo cenário íntimo da vida burguesa oitocentista. Com o esvaziamento do espaço público, os elementos arquitetônicos que ornavam as cidades antigas, escalinatas, halls, etc., são transpostos para o interior das casas. Sem dúvida outra manifestação típica da agorafobia. Mais ou menos 40 anos depois, Walter Benjamin voltaria a focalizar em suas notas sobre Paris do século XIX, este mesmo fenômeno de refluxo da vida urbana, ${ }^{15}$ tirando consequências que interessam na periodização e conceituação do pensamento arquitetôni-

13. Sitte, em especial cap. $X$.

14. A solução proposta inspira-se nas praças barrocas, tendo em vista a própria configuração urbana e arquitetônica tradicional vienense.

15. Cf. Benjamin."Paris, capital do século XIX” (vs. eds.). In Iluminaciones II, Madri: Taurus, 1972 (pp. 171 a 190); p. 183. 
co contemporâneo às voltas com os paradoxos da modernização. O que procura um burguês à cata de um refúgio doméstico? Obviamente compensar a impessoalidade da grande cidade; por isso multiplica com calculada redundância os traços da vida privada entre quatro paredes do seu asilo. Transformar em consequência a casa num estojo de objetos, de preferência os que preservam a marca pessoal inclusive no seu sentido literal, daí a inclinação pelos veludos e pelúcias, que guardam emblematicamente as marcas de qualquer contacto físico. Esses os acessórios do cenário teatral em que o burguês oitocentista transforma seus salões e alcovas - objetos também de um novo tipo de colecionador, de uma nova relação com a forma-mercadoria. O mais importante, todavia, do ângulo deste Roteiro, é notar que essa caixa fantasmagórica ia definindo uma nova concepção de moradia, decorrência da mencionada agorafobia. Habitar (e por conseguinte construir) passa a significar doravante deixar impressões (como o ladrão deixa impressões digitais), "rastros" de uma vida imediata que se sente ameaçada pela rua, vida imediata em que uma singularidade se exprime por oposição ao mundo exterior como algo interior, anímico, espiritual.

Onde afinal, a alienação? Na praça esvaziada, porém repleta por uma multidão solitária, ou no mito habilidosamente construído da interioridade? De resto - prosseguia Benjamin, que acabamos de comentar livremente - a crise do intérieur burguês não tardaria a se declarar. Esse quadro fictício, a casa, começaria a ser desfeito no fim do século pelo Modern Style. ${ }^{16}$ À primeira vista pareceria ocorrer o contrário: a apoteose da alma solitária não é a

16. “Experiência e Pobreza”, in Benjamin. Obras Escolhidas I, São Paulo: Brasiliense, 1985 (pp. 114 a 119). meta do Art Nouveau? Para ele a casa não deve ser justamente a expressão de uma personalidade? O ornamento não está para a casa expressiva de seu proprietário como a assinatura para o quadro? Deu-se todavia o contrário com aquela virada estilística global, os vestígios, os rastros da vida interior começaram a ser apagados - sem aliás que com isso seu espaço complementar, a dimensão pública da existência tenha sido reanimada, pelo menos no sentido urbanístico que a tradição lhe conferira. É que aquele nicho de pelúcia e bibelôs começa a ser devassado. É da lógica do sistema que negócios e trabalho passem a preponderar na definição do quadro de vida de um indivíduo moderno. Com isso a moradia tende a se tornar um espaço indiferenciado, um processo que culmina, como se sabe, com a arquitetura do vidro, um material antiaurático por excelência, como lembrou certa vez o mesmo Benjamin. Interior e exterior voltam novamente a se entrelaçar, ambos porém exauridos - esse o ponto de partida dos modernos, a nova "pobreza".

\section{A experiência da Metrópole}

O que ficara implícito no diagnóstico de Camillo Sitte reaparecerá em vários outros teóricos das patologias das Grandes Metrópoles. Assim, uma variante da "existência matemática" e da "doença nervosa" que a acompanha, identificada por Sitte como a agorafobia do habitante das cidades modernas, pode ser reconhecida nas considerações de um quase contemporâneo seu, Georg Simmel possivelmente o primeiro sociólogo da modernidade ao tematizar a intensificação da "vida nervosa" como a base psicológica do tipo metropolitano. Mas se ambos con- 
vergem na descrição de alguns traços de comportamento e veem com igual desconfiança a reclusão do homem moderno no espaço confinado da casa, enquanto Sitte imaginava que a recomposição da vida pública dependia de uma reordenação do espaço urbano - de modo a criar lugares similares aos das praças nas cidades tradicionais, onde a sociabilidade era efetiva -; Simmel acreditava que as grandes metrópoles haviam proporcionado ao homem uma quantidade e qualidade de liberdade pessoal sem paralelo em nenhuma outra forma de organização grupal ou urbana. Em contraste com a vida nas cidades da Antiguidade e Idade Média, chegou a afirmar que as barreiras que lá havia na relação do indivíduo com o mundo externo e consigo próprio, com sua independência e diferença, eram de tal ordem, que o homem moderno não poderia respirar.

"O homem metropolitano é livre em um sentido espiritualizado e refinado, em contraste com a pequenez e preconceitos que atrofiam o homem da cidade pequena. Pois a reserva e a indiferença recíprocas e as condições de vida intelectual dos grandes círculos nunca são sentidas mais fortemente pelo indivíduo, no impacto que causam em sua independência, do que na multidão mais concentrada da grande cidade." 17

Esse mesmo tema da vida nervosa ressurge novamente em Benjamin quando descreve a experiência de "choque" nas metrópoles, mais exatamente, a reação defensiva desencadeada pelo choque, neutralizada entretanto na "vivência-hábito" graças à intermediação da consciência.

17. Simmel. "A Metrópole e a vida mental”, in Velho, Otávio (org.) O fenômeno urbano, Rio de Janeiro: Zahar, 1973 (pp. 10 a 25); pp. 19/20.
Também Simmel via no intelecto um órgão protetor e a chave do comportamento do homem citadino - o indivíduo blasé. Mas, lembra Cacciari que os estudou conjuntamente, embora os dois autores em questão concordem em ver a Metrópole como o foco de um processo de "espiritualização" - como designa um dos tópicos centrais da sociologia alemã da modernização que associa o nascimento da razão formal à preponderância do cálculo, do interesse, etc., nas relações sociais abstratas que caracterizam a nova ordem burguesa - , divergem quanto ao significado dessa constelação: Simmel veria no tipo metropolitano de indivíduo, em que culmina a "espiritualização" (o Lukács da História e Consciência de Classe, falaria em formalismo e reificação), o momento determinante da "existência" moderna; enquanto para Benjamin seria a expressão acabada do domínio do capital como estrutura da sociedade.

Não ficam aí os contrastes entre os dois autores, segundo o mesmo teórico da Escola de Veneza: para Simmel, "vida nervosa" e "intelecto" (entendimento ou razão formal) acabam por se reunificar como o fazem o individual e o geral, ao passo que para Benjamin figuram, pelo contrário, a contradição básica do capitalismo e o respectivo conflito de classe, sendo, portanto, instável todo o equilíbrio, e por conseguinte meramente ideológica a reconciliação imaginada por Simmel. ${ }^{18}$ Para este, Nervenleben e Verstand (ao contrário do que ocorre no raciocínio negativo de Benjamin, que vê na crise um estado permanente) formam uma antítese cujos termos são continuamente confirmados e superados. A “intensificação da vida nervosa resultante da rápida e ininterrupta variação das impressões exteriores e interiores", como diz o próprio

18. Cacciari, op. cit.; p. 89. 
Simmel, acaba sendo sublimada pelo Intelecto (ou Entendimento, na terminologia filosófica alemã) — uma espécie de "intensificação da consciência" que compreende estes estímulos, os distingue e articula. ${ }^{19}$ Ao mesmo tempo, continua Cacciari, a "vida nervosa" é condição do "intelecto", ou seja, o mencionado "processo de espiritualização é o mesmo que a intensificação da vida nervosa levada às suas últimas consequências". ${ }^{20}$

Vida nervosa e metropolitana que corresponde à contínua transformação de valor de uso em valor de troca - sendo a metrópole a sede da economia monetária, esta última e o intelecto estão intrinsecamente vinculados, na grande cidade concebida por Simmel: abstração, troca de equivalentes, vida prosaica e entendimento constituem um mesmo sistema. O "intelecto" está assim ajustado ao mecanismo de produção e reprodução de mercadorias; no que respeita a substância do valor de uso ele é tão nivelador quanto o dinheiro . O indivíduo metropolitano por assim dizer interioriza a estratégia de reprodução desse sistema. Modelado pelo cálculo que especifica o âmago da razão formal, seu comportamento típico vem a ser o do homem blasé, encarnação da ideologia própria da Metrópole: arrematando a lógica monetária da transformação da qualidade em quantidade, no tipo blasé exprime-se a mais acabada indiferença pela individualidade de seres e coisas, que aliás já não discrimina mais - numa palavra, autopreservação pela desvalorização do mundo objetivo. Tal dissociação é uma das formas elementares da sociabilidade na grande metrópole. Ocorre, todavia, que no indi-

19. Simmel, op. cit.; pp. 12/13.

20. Cacciari, ibidem; pp. $83 / 84$. víduo blasé a individualidade, que se trata em princípio de preservar pela distância da indiferença, é a primeira a ser negada. O seu desencanto exprime o negativo interiorizado. Tudo isso não obstante, Simmel arremata sua análise da experiência negativa da Metrópole reconhecendo nesses fenômenos a afirmação moderna da liberdade e do desenvolvimento do Homem. ${ }^{21}$

Portanto, comparado, por exemplo, com o homem da sociedade tradicional, só o metropolitano será dito livre no sentido da "espiritualização" que caracteriza o mundo moderno. ${ }^{22}$ Assim, da divisão social do trabalho, condição desta mesma "espiritualização" supostamente emancipadora das peias tradicionais, às extravagâncias do blasé como modo de vida, o que foi tomando forma nesta reconstituição da vida metropolitana é algo que se poderia chamar de ideologia da síntese: a suposição de que o triunfo da individualidade extrema produzida pela grande cidade redunde na interiorização da totalidade que a tornou possível - o que aliás é alheio ao raciocínio efetivo do tipo blasé. ${ }^{23}$ Simmel não é conservador, mas também não é utópico, por isso reduz a forma da cidade - historicamente específica do domínio do capital - à simples expressão da individualidade na metrópole.

A Nervenleben tematizada por Simmel nos termos que se viu, e que se transforma em Benjamin na experiência de choque, está portanto diretamente associada à relação com as massas nas grandes cidades. Neste quadro, a aparição do único descrita por Benjamin é instantânea

21. Ibid.; pp. 87/89.

22. Simmel, op. cit.; p. 18.

23. Com outras palavras é o que diz Cacciari. Op. cit.; p. 90. 
e evanescente como a passante baudelairiana (aí o choque); experiência análoga à do flâneur, um tipo dos períodos de transição, não por acaso um personagem que se mantém no "limiar da grande cidade". Mas agora a lógica do choque vem à tona: onde Simmel busca consolo - continua Cacciari - , o pensamento negativo benjaminiano dá a palavra ao drama da alienação que se desenrola na Metrópole. A relação com a massa urbana é sempre catastrófica, pois nela aflora o seu trauma de origem. Para Cacciari, entretanto, Benjamin teria deixado sem tematizar a instrumentalização produtiva do choque pelo sistema, a incorporação da alienação pelo aparato montado pelo Intelecto (a carapaça protetora e ordenadora de que cogitava Simmel), a demolição da reconciliação entre comunidade e sociedade pela "vontade de poder" encarnada pela $\mathrm{Me}$ trópole. Ora, Haussmann irá criar a forma dessa violência. A tragédia de Baudelaire é a vitória de Haussmann. ${ }^{24}$

Quando muito o reformador de Paris armou um novo cenário para a luta de classes. E a questão que se coloca para o arquiteto-urbanista é precisamente a seguinte: como atuar, interferindo nessa lógica da metrópole, cuja forma acabada vem a ser a cidade haussmanniana contra a qual reagia Camillo Sitte, forma que encontrará em Le Corbusier um fiel seguidor. ${ }^{25}$ Uma coisa pelo menos é certa, não há como criar sucedâneos para um gênero abolido de existência, nem mascarar a contradição básica da forma-cidade. Trata-se sem dúvida de superar o atual estado

\section{Ibid.; p. 102.}

25. Cf. Le Corbusier sobre Haussmann, in L'Urbanisme (vs.eds.), onde faz a defesa da "coragem" do reformador parisiense, bem como da necessidade em seguir seu exemplo, realizando verdadeiras intervenções "cirúrgicas" nos centros urbanos das grandes cidades, não só meras "terapias”. de coisas - quem o negaria? - , porém não é menos imperativo (como espero tenha ficado claro a partir de Simmel) arquivar a ideologia projetista antecipatória e totalizadora que no final das contas acaba reproduzindo a vontade de poder a que se aludiu. Como também se foram as ilusões acerca da resolução urbanístico-arquitetônica dos conflitos que definem o espaço urbano, temos uma razão a mais para não ceder à tentação do "agorismo" consolador, na expressão rebarbativa de Otávio Paz.

\section{O mito da polis moderna}

Na virada do século, as filosofias da Vida, da Intuição, etc., buscaram no imediato o fundamento sobre o qual basear a reconstituição da experiência. Segundo observou certa vez Adorno, prova de que o imediato se perdera na rede sem começo nem fim das mediações: quanto mais se alega a vida como princípio, menos ela está presente na origem buscada em vão. A cidade moderna é a imagem mesmo dessa mediação sem trégua. Nos termos do nosso problema: quanto mais se procura refúgio no intérieur protegido e espontâneo da esfera privada, mais palpável a sensação contrária de que tal núcleo irredutível está inteiramente voltado para o exterior. Novamente a melhor demonstração do esvaziamento recíproco do público e do privado está na arquitetura de vidro que consagra a morte dos dois na abolição ostensiva da fronteira entre ambos. Outro efeito ou sintoma igualmente probatório é a crescente indiferenciação dos espaços, a ponto de não se distinguir mais residência e escritório, o âmbito doméstico da casa e a circulação de mercadorias na rua. Porém na mesma proporção em que se consolida a sociedade de massa, aumen- 
ta o domínio privado, mas entendido agora como o regime do falso imediato. Assim, a forma das grandes metrópoles - onde as praças (para continuarmos com nosso fio condutor) se transformaram em simples ponto de passagem, e as ruas, lugares suportes de fluxo de circulação para os conjuntos verticais - constitui, como ficou dito acima, a ilustração mais eloquente das novas relações entre o público e o privado. Como observou Sennet, o espaço público tornou-se um derivado do movimento. ${ }^{26}$

Ao teorizar o declínio do homem público e o correspondente alargamento da esfera privada, porém desfigurada como intimidade narcisista, Sennet tira consequências desse quadro geral no plano das patologias urbanas e suas repercussões no pensamento arquitetônico. A principal inspiração dessa literatura mais recente de revalorização polêmica da vida pública, Sennet incluído, vem sem dúvida de Hannah Arendt, embora suas reflexões provenham de um outro horizonte, a situação-limite do totalitarismo. Interessa portanto rever rapidamente neste Roteiro de referências o teor de sua apologia do mundo público, ainda que não encontremos nela a intenção explícita de reorganizar a morfologia urbana em função de sua concepção de cidade como cristalização tangível da vida ativa. ${ }^{27}$ É sabido que Hannah Arendt foi buscar na polis grega o modelo a partir do qual julgar as transformações modernas da esfera pública. Mais especificamente, tomou como paradigma uma interpretação da política antiga como domínio da ação em conjunto, ação desencadeada pela prática discur-

26. Cf. “A morte do espaço público", in Sennet, op. cit. Na trad. francesa - La tyranie de l'intimité, Paris: Seuil, 1979; pp. 22/23.

27. Cf. Arendt, Hannah. A Condição Humana, São Paulo: Forense Universitária, Salamandra, EDUSP, 1981. siva exercida entre iguais. Em função desse paradigma — a ação comunicativa por excelência — não só interpretou a distinção antiga entre o público e o privado, como avaliou o seu concomitante declínio moderno. Ao lado luminoso da vida pública em comum, atribuiu a liberdade e individuação, ao passo que no âmbito privado viu o seu contrário, a estreiteza da família, hierarquizada, dominada pela autoridade incontrastável do patriarca, confinada às dimensões estreitas de uma casa, também lugar etimológico (oikós) da reprodução "econômica" da vida, reino do "labor" e da necessidade - aqui privado era sinônimo de privação.

A transição do antigo para o moderno desfez esta distribuição harmoniosa das funções sociais, ou por outra, alargando indefinidamente o território privado conforme se implantava a propriedade burguesa, não só o debilitou ainda mais como precipitou o declínio inelutável do caráter público da liberdade. Um processo de substituição da ação (a práxis dos antigos) pelo comportamento (o enquadramento social regido pela reprodução material do sistema) que culmina no eclipse da visibilidade pública na sociedade de massa. O privado é o que não aparece (no mundo público comum), é o reino do obscuro, do irrelevante, da mais aguda limitação. Este foco de conformismo (que se alastra pelo corpo social à medida que o público se transforma na reunião dos proprietários) chega a delimitar e qualificar um espaço próprio. É o que se pode depreender de uma observação de H. Arendt acerca da apologia moderna das “pequenas coisas”. Não há maior expressão do refluxo da vida pública. É o que sucede com o "petite bonheur" à francesa, cujo culto, não por acaso, se consolida com o declínio da vida pública na França uma vez encerrado o grande ciclo revolucionário: é neste 
momento que o povo francês inventa a pequena felicidade entre quatro paredes, "entre o armário e a cama, entre a mesa e a cadeira, entre o cão, o gato e o vaso de flores". Último recanto onde se pode respirar humanidade? Aqui, nesta figura recente do intérieur, a ilusão moderna por excelência.

Trata-se de fato de um desenraizamento - na acepção em que $\mathrm{H}$. Arendt deu ao termo nos seus escritos sobre o totalitarismo em que se resolve a sociedade de massa. Não pode haver humanidade onde não há mais espaço cívico. Embora não o especifique, sua conceituação implica em um certo número de imagens espaciais sugestivas da correspondência entre reflexão sobre a "condição humana" moderna e a organização social do espaço. Seria o caso de se falar de uma anomia urbana a propósito desse grau zero do mundo público que é o totalitarismo. Podemos dizer que ao isolamento social que o define corresponde um espaço desolado, habitado por indivíduos supérfluos, quer dizer, justamente sem lugar - por certo um lugar (nos dois sentidos) que só a ação conjunta da vida em público pode instaurar. Mas para isso seria preciso encontrar um sucedâneo moderno que restaurasse, literalmente inclusive, a cidade antiga, corpo político e forma urbana, se completarmos nessa direção o argumento de Hannah Arendt.

Um argumento antimoderno, como sublinharam todos os seus críticos, vendo nele sobretudo uma estilização da imagem da polis grega incompatível com a atual articulação capitalista de estado e sociedade civil, como lembrou, entre outros, Habermas, destacando a incongruência das dicotomias de $\mathrm{H}$. Arendt (estado e economia, liberdade e bem-estar, atividade político-prática e produção) e o processo de modernização que elas por isso mesmo se mostram incapazes de descrever. É bem verda- de que Habermas - outro teórico da esfera pública - lhe deve muito do que entenderá depois por ação comunicativa e geração discursiva do poder político. Pode-se dizer também que, assim como Hannah Arendt idealizou a política dos antigos, Habermas não deixou de sublimar as virtualidades da esfera pública burguesa no seu nascimento, em função da qual avaliou sua desagregação na era pós-liberal. Mas não cabe aqui reproduzir sua demonstração. ${ }^{28}$ É preciso contudo assinalar, no que concerne a expressão urbano-arquitetônica desse esvaziamento da esfera pública que acompanha o fetichismo crescente da "intimidade" do intérieur em vias de desaparecimento, que Habermas não parece ceder à tentação de associar ao projeto moderno de reconstituição do mundo coletivo-consensual da ação comunicativa pública, uma restauração concomitante da urbanidade, nos moldes cogitados, por exemplo, por um Camillo Sitte. É o que se pode depreender de sua análise do desastre urbano em que culminou a metrópole contemporânea.

Não vem ao caso agora ${ }^{29}$ a avaliação que faz quanto à responsabilidade da Arquitetura Moderna neste capítulo crucial. ${ }^{30} \mathrm{O}$ ponto de vista a ser assinalado é que Habermas vincula a formação coletiva de uma vontade democrática à instituição de uma esfera pública de comunicação não-coercitiva sem, no entanto, ter ilusões quan-

28. Cf. A mudança estrutural da esfera pública, Rio de Janeiro: Tempo Brasileiro, 1984

29. Cf. Arantes, Otília e Arantes, Paulo. Um ponto cego no projeto moderno de Jürgen Habermas, São Paulo: Ed. Brasiliense, 1992. (Disponibilizado nesta plataforma).

30. Cf. "Arquitetura Moderna e Pós-Moderna”, in Revista Novos Estudos, $n^{\circ}$ 18, São Paulo, 1987 (pp.115-124). 
to ao seu complemento urbano. Ou seja, a forma de vida exigida como suporte e alimento do mundo público a ser recomposto à contracorrente do capitalismo avançado já não pode contar mais com a forma outrora abarcável da cidade. As aglomerações urbanas deixaram de corresponder ao conceito de cidade; neles predominam as conexões funcionais não configuráveis, sem a visibilidade do lugar público, incomensuráveis portanto com a clareza da autocompreensão prática que caracteriza um mundo de vida. Resta saber onde Habermas irá buscar apoio social para a sua esfera pública pós-burguesa (excluído o paradigma a seu ver produtivo do trabalho) - certamente não naquilo que ele mesmo denuncia como "o fetiche de uma presença comunitária". ${ }^{31}$ Porém é certo que não lhe faltam dados de observação para incluir a demanda de um lugar como configuração plástica de um mundo de vida pública no elenco das ideologias da infracomplexidade - o lugar do “espaço” público já não pode mais alcançar uma "presença” esteticamente apreensível.

Seja como for, o arquiteto precisa se precaver contra essas reconciliações forçadas, contra a "ilusão da experiência" (autêntica, comunitária, etc.), como Sennet designou as falsas sínteses e conflitos que atravessam o espaço de "choque" em que se converteu o espaço urbano. Quando os planejadores urbanos "querem de boa fé melhorar a qualidade de vida tornando-a mais íntima, não estão recriando o espaço estéril que querem justamente suprimir?"32 Pois deve ter ficado claro que o fetiche da intimidade e o seu complemento, a agorafobia,

31. Cf. A mudança estrutural da esfera pública; p. 188.

32. Sennet, op. cit.; p. 247. simplesmente repercutem a desolação do espaço público; reforçar os primeiros é agravar o segundo fenômeno. Resta saber se uma intervenção urbana deliberadamente "modesta", pontual e discreta, como a imaginaram muitos arquitetos e urbanistas, sobretudo nos anos 60 e 70, poderá de fato contornar a patologia moderna que se exprime no eclipse do lugar público, ou se está condenada a permanecer mero gesto ideológico. Sennet não esconde sua confiança na transformação da cidade moderna, que voltaria a ser um "lugar da vida social ativa, um lugar em que se possa revelar e viver todas as possibilidades humanas". ${ }^{33}$ Num livro publicado em 1970 sobre "os usos da desordem" ${ }^{34}$, defendia, em oposição ao controle pré-planificado da cidade moderna funcional, um "urbanismo anárquico", que propiciasse uma vasta rede de contatos sociais diferenciados entre camadas diversas de população e em lugares de atividades e funções múltiplas, de modo a gerar novas formas de instituições urbanas e de autorregulação mais eficazes. Os problemas que levanta não deixam de estar em linha de continuidade com os que formulara Jane Jacobs, no conhecido livro The Death and Life of the Great American Cities, ao resumir a experiência americana dos anos 50; embora Sennet não se reconheça numa posição que considera ainda nostálgica, alimentada pela ideia de relações íntimas entre vizinhos. De fato, a vida urbana que Jacobs procura generalizar é a do bairro de Greenwich Village - o que seguramente não corresponde às novas exigências das Grandes Me-

33. Ibid.; p. 276.

34. The Uses of Disorder: Personal Identity and City Life, NY, Alfred Knopf, 1970 . 
trópoles ${ }^{35}$-; enquanto Sennet pretende estar propondo uma estratégia urbana à altura de uma "era opulenta e tecnológica”. Podemos contudo nos perguntar até onde uma tal posição não acaba por neutralizar os conflitos numa consagração estética das diferenças, conduzindo facilmente a uma apologia do caos (como, por exemplo, em Shinohara), onde em geral a mais perversa especulação imobiliária acaba sendo interpretada como uma espontânea e saudável criatividade.

Habermas, pelo contrário, que neste tópico particular não confia mais nem mesmo no Movimento Moderno, do qual é um dos últimos ideólogos, se pergunta se o próprio conceito de cidade já não estaria ultrapassado. ${ }^{36} \mathrm{Sem}$ pretender resolver a alternativa, voltemos ao percurso cumprido pelo renascimento da ideia de lugar público no pensamento urbanístico-arquitetônico.

\section{Dos grandes bulevares ao "coração da cidade"}

Face às reformas do barão Haussmann, em que o que qualifica a cidade é o próprio traçado urbano ideal e funcional - um paradigma não só para a maior parte das intervenções urbanas que se sucederam na segunda metade do século XIX, mas também para a maioria das tendências da

35. Cf. Berman, Marshall. Tudo que é sólido se desmancha no ar, São Paulo: Cia. das Letras, 1986; pp. 307/308. Sobre Jane Jacobs e as ambiguidades de uma posição como essa que "se move numa região crepuscular onde a linha que divide o mais rico e complexo modernismo da mais modernista e consumada má-fé antimodernista é muito tênue e esquiva, se é que de fato existe". Cf. também "O caminho do subúrbio: urbanistas e beats", in Russel JACOBY - Os últimos intelectuais, SP, Trajetória cultural e EDUSP, 1990 (pp. 66 a 83).

36. Cf. "Arquitetura Moderna e Pós-Moderna” cit. arquitetura moderna -, o "fórum Bonaparte" de Antolini, proposto em 1802 à comissão do governo da República Cisalpina para a reforma napoleônica de Milão, teria representado uma outra fonte de inspiração. É verdade que nos dois casos estamos diante de reformas urbanas cujo princípio é a modernização sem complacência. Mas aqui termina a semelhança. Haussmann reorganiza a cidade de acordo com os interesses do capital, como é sabido, por isso expulsa do centro de Paris seus antigos habitantes, implanta uma forma sectária de metrópole, decomposta em setores, aberta tanto para a circulação de mercadorias como de tropas em guerra contra as barricadas, favorecendo de caso pensado a especulação imobiliária e a discriminação social, e assim, afirmando a vontade de poder da cidade como forma "especulativa", para falar como Cacciari.

Antolini, ao contrário, imaginara uma reestruturação da cidade que introduzisse, na trama de seus valores contraditórios, um espaço urbano singular, capaz de irradiar efeitos tais que estabelecessem uma espécie de comunicação imediata com a população - enfim, nas palavras de outro teórico da escola de Veneza, Manfredo Tafuri, “um símbolo carregado de valores ideológicos absolutos, um lugar urbano que, como presença totalizadora, se propõe como finalidade mudar toda a estrutura urbana, recuperando para a arquitetura um papel comunicativo de valor imediato"37. Ora, quase um século mais tarde, uma proposta semelhante, embora nem sempre animada pela mesma intenção totalizadora (que então já aparecia como uma ilusão), será apresentada por dissidentes da urbanís-

37. Tafuri. "Por una critica de la ideologia arquitectonica", in op. cit. (pp. 13 a 78); cf. p. 28 
tica do Movimento Moderno, em particular opositores da orientação predominantemente haussmanniano-corbusiana. A ideia diretora era a reativação, ou criação, de lugares com sentido forte, em geral ligados a práticas coletivas que impregnam a representação e a "vivência" da cidade pelos seus habitantes. Com isto, e dispensando-se o recurso a modelos, a cidade deveria em princípio voltar a ser uma res cívica, como queria Camillo Sitte ao criticar a reforma vienense do Ring.

Pode-se dizer que coube a Giedion, ainda durante a Segunda Guerra, e seguramente como forma de resistência a uma política de gestão urbana própria aos regimes totalitários, a iniciativa do debate, ao expor, num texto redigido em colaboração com Sert e Leger, a questão da necessidade emocional e cultural dos monumentos na reorganização da vida coletiva, para o exercício da qual proporá também, cinco anos depois, em 1948, a criação de centros especiais ${ }^{38}$. Mas, a essa altura, ele já está de fato ratificando as críticas severas à cidade funcional, feitas um ano antes no CIAM de 47, em Brigwater. Finalmente, em 1951, o grupo inglês MARS apresenta como tema para o Congresso a recentralização da cidade dispersa pelo zoneamento funcional moderno, através de um espaço físico - "o coração da cidade" - "em que se possa manifestar o sentido da comunidade". Como o nome indica, nesse espaço residiria o centro vital da cidade. ${ }^{39}$ Ainda uma intervenção drástica? Rogers fala em mudar, restabelecer, vivificar ou inventar um tal centro.

38. Giedion. Architecture et vie collective, Paris: Denoel/Gonthier (coll Médiations), 1980; pp. 41 a 71.

39. Sobre o $8^{\circ}$ Congresso do CIAM cf. ROGERS, SERT, TYRWITT, Il cuore della cittá , Milão: HOEPLI, 1954.
Todos concordam com a sua necessidade, mas nem todos o concebem da mesma maneira.

Os mestres Gropius e Corbusier estavam presentes neste Congresso. Quando intervêm mostram-se preocupados com a escala humana desse centro, mas suas propostas vão em sentido oposto. Para Le Corbusier, deveria ser um espaço em que as pessoas pudessem ver e ser vistas. Neste ponto, todos evocam o ágora grego, onde os cidadãos eram ao mesmo tempo atores e espectadores um centro portanto de visibilidade máxima como queria H. Arendt. Mas "como construir um core na ausência de toda estrutura social claramente definida?" pergunta-se Giedion, embora defenda a tese. Nada mais distante, ou melhor diametralmente oposto, do que o modelo imaginado por Le Corbusier: o vale cívico de Chandighar, cuja artificialidade é bem conhecida, sem falar no seu espaço superdimensionado, mais um motivo para que permaneça deserto; além disso trata-se de um centro administrativo, da sede do poder, sem dúvida um elemento de identificação no plano da representação da cidade, porém de modo algum presente na sua "vivência", de que cogitavam os que queriam uma revisão radical da urbanística dos modernos (para grande parte dos que estavam reunidos naquele Congresso o "coração da cidade", para ser um centro vivo, deveria ser plurifuncional). No outro extremo, Gropius citava como modelo para meditação as praças italianas, lastimando, como contava, não ter conseguido converter seus alunos americanos para este tipo de espaço urbano - seguramente uma sugestão tão deslocada quanto o vale cívico de Chandighar.

Diante das dificuldades para encontrar ou criar tais espaços que viessem a reanimar as cidades, Sert chega a sugerir a multiplicação desses corações urbanos, fugindo 
pelo menos da concepção totalizadora e hierárquica predominante na maioria das teses sobre o core - no entanto continuava insistindo na necessidade de uma referência básica, embora atenuada por reflexos locais, obrigatoriamente de caráter cívico. Aos poucos essas teorias e as propostas correspondentes foram revelando sua inviabilidade. Voltou-se então a pensar a cidade como um todo antes fragmentado do que unificado por um centro vital, embora ela já não fosse mais avaliada do ângulo da performance funcional de suas partes.

Não obstante, continuam a se multiplicar outras propostas de intervenção visando deter a desagregação da cidade moderna. Por exemplo, dissolvendo-se os CIAM em 1956, constitui-se o TEAM X, reunindo Bakema, V. Eyck, Allinson e Peter Smithson, Candilis, Shad Woods, De Carlo, Coderch, Pologni, Soltan e Wewerka. Malgrado as divergências, a tendência comum era partir de uma unidade, a casa, para o todo, uma visão concêntrica portanto: casa, rua, bairro, cidade. Muitos se dedicaram a projetos de conjuntos residenciais com espaços de convívio, lazer ou serviços associados. Outros, como Bakema, retomam as lições do primeiro modernismo, especialmente no que concerne a planificação das Siedlungen, como se fazia na Alemanha de Weimar e na Holanda de entreguerras. Outros ainda, quando não os mesmos, projetarão megaestruturas - cidades concentradas, em geral de altura média e máxima densidade - mas que logo se mostrarão tão inóspitas e impessoais quanto as grandes cidades esparramadas: como era de se esperar, a proximidade não é por si só fator de interação social. ${ }^{40}$

40. Cf. sobre a história dos CIAM e do Team X, ver Frampton. Historia critica de la arquitectura moderna, Barcelona: GG, 1983; pp. 273 a 283.
É na esteira desses debates e propostas alternativas ainda desencontradas que muitos arquitetos, especialmente a partir dos anos 60, começarão a substituir as teorias do Plano por teorias do lugar, procurando conceber de modo menos abstrato, sistêmico, autoritário e instrumental a cidade.

\section{As teorias do Lugar}

Num livro que fez época há mais de vinte anos atrás - A Arquitetura da Cidade -, Aldo Rossi pôs em circulação um termo que a literatura especializada acabara esquecendo: o lugar, resultante, segundo ele, de "uma relação singular e sem embargo universal entre certa situação local e as construções aí sediadas". ${ }^{41}$ Para melhor destacar a importância do conceito proposto, remonta até os antigos, lembrando que para gregos e romanos era essencial o lugar de implante de uma cidade, local tutelado por divindades protetoras e mediadoras, os Genius Loci. Rossi lembra também que toda tratadística clássica retomara a noção de locus, porém despojada da dimensão mitológica e investida de uma outra cada vez mais profana, isto é, topográfica e funcional, como em Palladio e depois Milizia. O próprio Viollet-le-Duc, embora cuidando mais estritamente das operações lógicas fundamentais do fazer arquitetônico, teria admitido a dificuldade de transpor uma obra de um lugar para outro. Seguem-se, no repertório estabelecido por Rossi, geógrafos, antropólogos, etc., e mesmo um esteta, Focillon, que se refere a "lugares psicológicos" - a arte, considerada

41. La arquitectura de la ciudad, Barcelona: GG, 1983; p. 185. 
como uma individualidade própria. Os artistas - continua Rossi - sempre se basearam em algo originário, anterior ao estilo, nisto consistiria o lugar: um elemento prévio, responsável enfim pelo fundamento, na acepção mais enfática do termo. Afinal, o que determina a individualidade de um monumento, de uma cidade, de uma construção? Rossi respondia que devia ser alguma coisa relacionada com um vínculo local, numa palavra, com o lugar da obra: "fato singular determinado pelo espaço e pelo tempo, por sua dimensão topográfica e por sua forma, por ser sede de vicissitudes antigas e modernas, por sua memória”. O lugar, nesta acepção em que foi redescoberto, está longe portanto de se confundir com o espaço físico de implante da construção (algo em si mesmo neutro e desprovido de significação), embora dependa deste suporte material; de fato ele se cristaliza por assim dizer impregnando, circunscrevendo, um espaço determinado - qualificando-o ao convertê-lo num fato único, sobrecarregado de sentido (histórico, psicológico, etc.), camadas de significação que ultrapassam o seu ser bruto imediato. São, portanto, significações em grande parte coletivas, como lembra Rossi. ${ }^{42}$ Em nome dessa realidade única e complexa é que Aldo Rossi encara toda atividade projetual arquitetônica. Notemos o que ele entende como passagem do abstrato ao concreto: a abstração seria própria da intervenção modernista, a tábula rasa do Plano, ao passo que o concreto, expressão da unidade das significações insubstituíveis, resume a mudança de rumo (e uma palavra de ordem que outrora presidira o nascimento das filosofias da existência: rumo ao concreto) proposta pela nova arquitetura da cidade.

42. Ibid.; p. 189.
No mesmo ano da publicação do livro de Aldo Rossi, 1966, Samoná coordenou em Veneza um curso sobre Teoria do Projetar Arquitetônico, ${ }^{43}$ do qual participaram jovens arquitetos de maior projeção na época, entre eles o próprio Rossi, Gregotti, Tafuri, Canela, Aymonino, Semerani e Purini. A questão do lugar, entendido como algo mais do que o simples entorno físico, esteve presente em todo o seminário. Gregotti acabou sua comunicação definindo a arquitetura como "lugar simbólico", um tema que retoma e desenvolve num livro quase contemporâneo e igualmente marcante - O Território da Arquitetura. Nele reapresenta a noção de lugar como algo "antropogeográfico", para além do mero espaço físico, algo delimitado e instaurado pela atividade simbolizadora do homem. Aqui a inspiração mais próxima vem da filosofia das formas simbólicas, em particular de Cassirer e Suzanne Langer, onde a tônica recai sobre a intencionalidade significante da consciência, algo como uma força plástica responsável pela gênese de configurações simbólicas, (dos signos matem ticos ao mito) que independem de referência exterior prévia. "Como no caso da linguagem, o ambiente circundante é o produto dos esforços da imaginação e da memória coletiva que se explicam e realizam por meio das obras que o sujeito constrói quando se defronta com o mundo e, portanto, também com a sociedade". ${ }^{44}$ Dito isto, uma dificuldade, relativa ao reconhecimento das diferenças: "de que modo nossa percepção da paisagem se converte em percepção estética, de que modo se adquire consciência da qualidade fi-

43. Teoria de la proyectacion arquitectonica, Barcelona: GG, 1971.

44. Gregotti. O Território da Arquitetura, São Paulo: Perspectiva, 1978; pp. $64 / 65$. 
gurativa da paisagem?" Respondendo ao problema por ele mesmo formulado, Gregotti faz a seguinte distinção: de um lado, a postura mítica, que eleva um determinado lugar à dimensão do simbólico, manifestação visível de uma totalidade em primeira instância geográfica (neste ponto, é nítida a intenção do arquiteto de manter a transcendência num plano meramente mundano); de outro, a atitude propriamente artística, onde a identificação é decorrência do caráter de objeto desse lugar, de sorte que o reconhecemos como "figura". Mas a arquitetura como lugar simbólico é isso e muito mais: de alguma forma ela está sempre implicada na memória coletiva, nos valores de um grupo determinado, inclusive na economia local, de tal modo que o lugar se apresenta sempre como algo "construído historicamente enquanto decisão de destinação". ${ }^{45}$

A terminologia do curso traz a marca da época. A começar pela ambição de cientificidade que dominava as ciências humanas então promovidas pela voga estruturalista. É preciso em consequência rever os termos daquele debate sobre a atividade projetual dando o devido desconto do preço pago às ideias dominantes na inteligência do tempo. Assim transcrita, a cidade passava a ser vista como uma rede de relações diacrônicas e sincrônicas, onde o lugar aparece neste corte estrutural de espaço e tempo, condensação simultânea de vários tempos e valores históricos. Daí a discussão passava inevitavelmente à questão tipológica, ou seja, às invariantes arquitetônicos ao longo da história e suas relações com a morfologia urbana, numa palavra, com a configuração do lugar, o qual, embora represente um corte horizontal no processo de trans-

45. Ibid.; pp. 65 a 67 . formação da cidade, como se fosse um eixo sintagmático a articular a sintaxe dos objetos em questão, também é paradigmático: organiza estas relações dando-lhes sentido. "O verdadeiro avanço", dizia Gregotti, "é feito sempre de descontinuidade, desarticulação, mas define-se enquanto tal em relação a algo, isto é, em relação à sedimentação histórica do presente". ${ }^{46}$ Nessa direção, contrapondo-se à noção de história dos mestres do Movimento Moderno, Gregotti imaginava o tempo histórico como algo suscetível de uma espécie de escavação rumo aos estratos ocultos de um fenômeno de superfície, uma quase suspensão do movimento histórico como vinha propondo o estruturalismo: pensando na polêmica de Lévi-Strauss com Sartre, Gregotti alegava a seu favor que a pesquisa histórica ultimamente se concentrava na "construção de modelos de interpretação da história concebida como uma série de configurações sucessivas, descontínuas e que nós conscientemente colocamos em diferentes níveis de valor". ${ }^{47}$ A esta orientação, o arquiteto sobrepunha reminiscências do historicismo, as quais, tudo bem pensado, não deixam de ter o seu propósito, pois na ausência de uma progressão cumulativa, conta apenas a relatividade dos fenômenos localizados como instantes incomensuráveis de uma intriga histórica singular. Daí a ênfase no lugar-suporte.

Essa contaminação pelo estruturalismo não deixa de ser paradoxal. É verdade que era muito difícil desviar-se dela e expor a nova concepção da cidade e da atividade projetual com terminologia própria e adequada ao objeto. Pois se havia alguma coisa incompatível com o estrutura-

46. Ibid.; p. 138.

47. Ibid.; p. 143. 
lismo era a ideia de lugar, nos termos em que os arquitetos dissidentes do Movimento Moderno estavam tentando defini-lo. O lugar como foco de significações coletivas reúne tudo que o estruturalismo tentou demolir: a história, a continuidade, a memória, a tradição, a consciência (mesmo coletiva) enquanto fonte irredutível de sentido - enfim tudo aquilo que faria o sujeito (o inimigo mortal daquele ideário) sentir-se em casa, reconhecer-se nalgum monumento, na prática acumulada de algum mundo de vida. Pelo contrário, o ponto de honra por assim dizer modernista do estruturalismo reside na extirpação de qualquer sentido, que tinha na conta de resíduo mítico ou metafísico num mundo completamente desencantado. Reinventar o lugar em sua unicidade insubstituível, se não for um total equívoco teórico, é apenas um artifício sentimental.

A aspiração fora de época pelo "concreto" exprimiria os dois lados da alternativa. O estruturalismo navegava a favor da corrente, a favor portanto da tábula rasa da modernização: assim, nada mais estranho ao seu espírito do que ressemantizar o que quer que seja, e a cidade não seria exceção, sobretudo dotada de um "coração", que por definição palpitaria no mesmo diapasão do "sujeito". Em suma, o lugar surgiria como uma relíquia pré-capitalista. Ocorre que esta também tinha sua razão de ser, se é verdade que a expansão da racionalização capitalista carrega consigo um foco de irracionalismo a um tempo compensatório e estrutural. Não por acaso o estruturalismo combinava esses dois elementos, positivismo e transgressão. Mas não é esta última o que os teóricos do lugar tinham em mente, pelo contrário, cogitavam da reconstrução de um vínculo orgânico que o deserto moderno desfizera. Gregotti falava de um "ambiente total", no qual deveria se refletir uma sorte de ordem cronológica que o pensamento arquitetônico precisava reconquistar. Daí ao Heidegger, de “Construir, Habitar, Pensar", o passo era imediato, tanto mais que o segundo Heidegger (e não o primeiro, que inspirara o extinto Existencialismo) voltara a circular nos meios estruturalistas, ilustrando a repartição ideológica mencionada linhas acima.

A conferência de Heidegger não trata obviamente de arquitetura, como ele mesmo adverte. Não só não trata de arquitetura como ilustra um modo de pensar declaradamente hostil ao principal objeto dela, a vida urbana e suas consequências. ${ }^{48}$ Nisto Heidegger não era original. Com raras exceções, uma das características da inteligência alemã é a difamação sistemática da dimensão pública da vida em sociedade. Heidegger simplesmente deu uma coloração metafísica a esse sentimento antimoderno, acrescentando-lhe novas especificações “existenciais”. Ora, o principal inimigo da existência "autêntica" (a vida apolítica que leva um povo de poetas e pensadores, mas não de cidadãos) é a cidade. Nela impera a mais acabada "tagarelice”, o domínio impessoal do "se". A rememoração do ser, pelo contrário, exige a interioridade que só o isolamento propicia. Mas não se trata de um isolamento qualquer: para exibir a marca de autenticidade é preciso combater todas as manifestações de urbanidade moderna - do Iluminismo ao objeto industrial fabricado em série, contrapondo-lhe a apologia dos seus contrapesos tradicionais, do anti-intelectualismo à primitiva destreza artesanal. Para não ser devassado pela arquitetura do vidro, o intérieur burguês sofre nova transformação, convertendo-se num fac-símile da choupana do camponês. Polemizando com a

48. In Conférences et Essais, Paris: Gallimard, 1958 (pp.170 a 193). 
metrópole, o fetiche da intimidade (correlato do declínio da esfera pública) tornou-se agora literalmente provinciano. Longe da capital, o Ser se manifesta numa cabana da Floresta Negra, de preferência nas noites de inverno. Desnecessário insistir no caráter postiço desse fervor bucólico na Alemanha moderna. Mais um lance desse travestimento - sem dúvida induzido pela história singular do país - e o arcaísmo local (antiurbano, por definição) torna-se fonte originária, proximidade do Ser, etc. Não por acaso os exemplos vão do templo pré-socrático à ponte da aldeia, que também não deixa de ser um templo, pois a força mítica, tectônica, que encerra, se revela na hora da verdade em que o usuário não a utiliza como simples meio de passagem. Sem nenhuma referência urbana, a arquitetura (tematizada indiretamente pela via especulativa dos fundamentos últimos) se reduz a algumas operações elementares. Curiosamente, o modelo é vernacular, para variar, a casa camponesa, há vários séculos edificada segundo a mesma sabedoria. Entre outras coisas, esta ensina que só constrói bem quem sabe morar - uma espécie de privilégio ontológico infuso, partilhado por uma elite espiritual e o camponês pré-socrático estilizado por ela. Está claro que o tipo urbano moldado pala metrópole moderna não sabe mais morar. Vive, portanto, sob o signo da inautenticidade, como traduz Heidegger um lugar comum do pensamento conservador alemão: numa palavra, quebrando os vínculos orgânicos da Comunidade, a cidade mecânica e abstrata desenraiza. Nestes termos, a questão da moradia deixa de ser um problema de economia política para se tornar expressão de uma crise ontológica.

Mesmo uma enormidade como esta, em que culmina o raciocínio antiurbano de Heidegger, não impediu que a conferência em questão tenha exercido considerável influência no debate arquitetônico destes últimos vinte anos, de Gregotti a Frampton . Não só foi muito lida e acatada como parece ter fornecido algumas coordenadas aos arquitetos preocupados em ressemantizar a cidade. Esta audiência se deve principalmente a dois pontos básicos que muitos devem ter julgado possível destacar do dúbio contexto de origem, as relações entre construir e habitar, espaço e lugar. Heidegger já havia dito numa passagem de Ser e Tempo (parágrafo 12), que a significação original do ser-no-mundo é o habitar, de sorte que o existencial "eu sou" remete a um estar-em-casa mais primitivo, e por enquanto ainda metafórico. Na conferência de 1951 tomará o habitar ao pé da letra, apresentando-o como o modo essencial da existência finita sobre a terra (sendo esta última um ente carregado de simbolismo e não meramente geográfico). Dirá então que este habitar originário é a condição e finalidade última de toda construção, de sorte que o ato de edificar passa a integrar a galeria dos gestos ontológicos fundantes. E como se isso não bastasse para seduzir um arquiteto - projetar uma casa não é o ato prosaico que se imagina, mas uma sondagem de nossas raízes ontológicas - também lhe é dito que essa construção-habitação confunde-se com a palavra inaugural do poeta-vate.

Apesar do terreno movediço de uma tal metafísica da construção, Gregotti não hesita em transcrever a seguinte passagem de Heidegger:

"É a poesia que faz habitar. E de que modo se chega à residência? Através do construir, mais que fazer habitar a poesia constrói. Encontramo-nos assim frente a uma dupla exigência: em primeiro lugar, pensar no que chamamos existência humana [lembramos que Heidegger prefere utilizar a expressão ek-sistência, ek-stase, retirando-lhe toda carga 
subjetivista] partindo da residência e, em segundo lugar, considerar a essência da poesia como fazer habitar; buscando a essência da poesia nesta direção, chegaremos à essência da morada" ${ }^{49}$

Mas ao que parece a redescoberta da dimensão poética da arquitetura não seduz Gregotti a ponto de fazê-lo subscrever o enunciado básico heideggeriano segundo o qual a verdadeira crise da habitação não é uma questão social de moradia, mas uma falha de enraizamento. Pois logo adiante Gregotti repõe a arquitetura na sua real base terrestre, voltando à "especificidade da matéria arquitetônica”, onde afloram o fator estrutural, o uso e a dimensão histórica. E no impasse, procurando conciliar história e estrutura, acaba recorrendo a uma concepção teleológica do projeto, à maneira sartriana reinterpretada por Argan em Projeto e Destino, onde o projeto é pensado como algo da ordem da decisão existencial: "O projetar apresenta-se, portanto, como uma resposta significativa, ou seja, poética, do habitar enquanto organização do a mbiente interno, mas seu modo concreto de ser é o seu realizar-se na situação histórica de seus materiais". ${ }^{50}$

No que diz respeito à segunda relação, já se observou que Heidegger inverteu os termos da questão. ${ }^{51} \mathrm{De}$ Tönnies a Spengler, o pensamento conservador e antimetrópole alemão, ao concentrar-se no tema do vínculo orgânico da Casa com a Comunidade, sempre concebeu a moradia como um prolongamento harmonioso do lugar

\section{Gregotti, op. cit.; p. 49.}

50. Ibid.; p. 57.

51. Cf. Dal Co, Francesco-Abitare nel Moderno, Bari; Laterza, 1982; pp.28/29. significativo prévio no qual ela sabiamente se implantou (a paisagem, a terra, uma natureza pré-histórica enfim) - em suma, a casa que enraíza é aquela que exprime um lugar que a precede. Heidegger reapresentou este mesmo ponto de honra ideológico na ordem inversa: é a habitação-construção que instaura o lugar. Assim, o espaço não encontra o seu fundamento nele mesmo, sua origem é o lugar - antes de se tornar uma abstração geométrica, ele resultou de uma operação tangível de delimitação: ele foi arrumado, disposto, arranjado, circunscrito por limites, e só estes lhe dão forma. Numa palavra, o lugar aberto e fundado pelo habitar-construir como a unidade da seguinte quadratura: estar sobre a terra, sob o céu, diante das divindades e ao lado dos mortais.

Neste jogo mitológico, o que foi feito de uma prática tão historicamente material e desencantada como a arquitetura dos tempos modernos? Por mais que Gregotti se deixe impregnar pela mitologia heideggeriana, não chega jamais a abandonar a perspectiva básica da atividade projetual, sobretudo se voltada para a instituição de um "lugar simbólico", como uma atividade racional prosaicamente socializada. Já nas concepções de seu ex-colaborador Purini, a ascendência heideggeriana parece ter pesado mais: o lugar não só vem referido a uma espécie de natureza infinita, mas deve ser circunscrito de modo tal que desperte sentimentos ambivalentes de temor e atração, por isso deve ser sublime como uma aparição inalcançável que não se deixa decifrar inteiramente, dotado inclusive de uma temporalidade cíclica como a dos mitos, e assim por diante. ${ }^{52}$ Em contrapartida, Gregotti está inteiramente voltado para a tecnologia moderna e a realida-

52. Purini, Luogo e Projetto, Roma: Ed. Kappa, 1982. 
de urbana, assinalando claramente em suas intervenções a distinção entre arquitetura e natureza (ou paisagem) veja-se os projetos residenciais em zonas periféricas, ou ainda a Universidade de Palermo (construída aliás com a colaboração de Purini), onde, se é verdade que a forma de ponte em meio às montanhas pode parecer reminiscência heideggeriana, a alta tecnologia empregada e os contrastes habilmente trabalhados desmentem qualquer identificação imediata com o entorno geográfico, aliás são duas estradas o que reúne a "Universidade-ponte". Por sua vez, Purini acredita que as emoções ligadas à arquitetura como lugar se devem a uma certa indistinção entre esta e a natureza. Em consequência, definir o lugar do seguinte modo: "quase uma redução da infinita história da natureza à relativa finitude da arquitetura”. Por isso caberá à arquitetura gerar experiências implicadas por uma temporalidade mítica e as correspondentes formas arquetípicas - não podemos esquecer da influência do americano Louis Kahn sobre este arquiteto italiano.

Se uma teoria como a de Purini confere ao lugar uma grande autonomia em relação às exigências mutáveis da comunidade que o ocupa, reportando-as a uma outra realidade, a do monumento ${ }^{53}$, as concepções de Rossi e Gregotti, muito mais preocupados com a dimensão antropológica e coletiva, darão outra importância ao que Purini deslocara para um plano diverso ao do lugar/natureza. Rossi, por exemplo, chega a atribuir um papel preponderante aos lugares monumentais na ordenação da cidade, chamando-os de fatos urbanos primários - núcleos mais sólidos na malha urbana, nós estruturais de significação, e isto não apenas do ponto de vista da percepção gestáltica

53. Ibid.; p. 28 da cidade, como pretendia Lynch, mas como focos irradiadores de uma operação racional. Esses núcleos funcionariam como motivos construtivos, desempenhando um papel decisivo na formação das cidades - podem ser templos, fortalezas, praças ou um conjunto de prédios, bem como o próprio plano da cidade. (Não será demais lembrar aqui o plano diretor de Brasília, seguramente uma imagem tão ou mais forte do que a dos palácios).

Num certo sentido, o monumento resume todas as questões urbanas importantes, mas se torna algo ainda mais especial - na observação de Rossi - quando, por sua beleza, transcende as exigências econômicas e práticas. Preocupado em localizar as invariantes históricas (daí a sensibilidade para o ideário estruturalista, de que falamos páginas atrás), recorre não apenas a uma tipologia arquitetônica onde os tipos surgem como formas sintéticas de um processo que se manifesta através deles, como também a lugares urbanos mais ou menos estáveis. Uns e outros são fatos primários com uma função sintética semelhante no que concerne os valores e a vida de um centro urbano: quando são então reunidos, podem compor uma "imagem analógica" da cidade. ${ }^{54}$ As funções desses lugares podem mudar, eles permanecem, porém, como referência básica do conjunto urbano e por consequência, de qualquer intervenção que porventura venha a ocorrer. Rossi costuma citar dois exemplos: o Palazzo della Ragione em Pádua, e a Alhambra de Granada - é verdade que hoje em dia o uso que se faz deles já não é mais o original, mesmo assim nunca deixaram de ser um importante foco de sig-

54. Cf. prefácio da 2a. ed. italiana da Arquitetura da Cidade; na trad. cit., p. 43. 
nificações para o entorno urbano. ${ }^{55}$ É dentro desse espírito que Rossi propõe a modernização de Veneza: manutenção dos lugares monumentais e renovação progressiva do resto. Não se trata evidentemente de uma solução similar à do Plan Voisin de Le Corbusier, uma vez que a nova cidade antevista pelo arquiteto italiano deve se ajustar aos referidos lugares e monumentos, integrando-os e não apenas preservando-os como peças de museu; tampouco consiste na mera repetição do que teria sido demolido, pois novos valores iriam sendo incorporados de modo a gerar novos fatos primários, com a mesma força dos anteriores. A nova cidade iria assim se constituindo como um acúmulo de acontecimentos históricos marcantes, antigos e recentes. ${ }^{56}$

Fica a pergunta: como produzir tais fatos primários? Numa linha bastante diversa de raciocínio, também Frampton acredita que o recurso aos monumentos seja a maneira de reagir ao triunfo da banalidade nas cidades contemporâneas. ${ }^{57} \mathrm{O}$ gosto pelo monumento parece ter aos poucos voltado e, como estamos vendo, associado via de regra à discussão da arquitetura ou da cidade como lugar de conteúdo simbólico forte.

55. Ibid., p. 101.

56. Cf. Rossi. "What is to be done with Old Cities?" in Architectural Design n. 55, Londres: 1985 (pp.19 a 23).

57. Frampton. "Avant Garde and Continuity”, in Architectural Design n. 7/8, 1982 (pp. 20 a 27).

\section{Monumentalidade ou retórica monumental?}

Esse novo gosto pelo monumento, promovendo a reativação de certos rituais, não estaria por assim dizer sacralizando o urbano? Ao se pretender expurgar a cidade moderna, eliminando tudo o que ela encerra de impessoal, de insignificante, cancelando os interesses materiais de toda ordem e os conflitos que a atravessam, não se estaria forjando identidades obviamente postiças? Essa é a opinião radical do novaiorquino Eisenman, que considera a preservação de lugares simbólicos, hoje completamente destituídos de valor, ou até mesmo a simples fixação de pontos significativos de referência para a população, uma intervenção autoritária. Assim, convidado pela Trienal de Milão, em 1987, para projetar uma intervenção no centro de Roma, Eisenman propôs o que chama de scaling a superposição, em escalas diferentes, do plano daquela região - , de modo a baralhar todas as referências fixas, libertando os romanos dos valores que, embora sem vigência, ainda lhe são impostos (mas ser que esta anulação das marcas tradicionais numa cidade como Roma não se constitui num ato tão ou mais autoritário?). Nos termos em que estamos formulando o problema neste Roteiro, seria o caso de se falar num projeto de dessemantização da cidade. Eisenman provavelmente preferiria falar em "desconstrução", transpondo agora para as aglomerações urbanas o que antes imaginara para a arquitetura enquanto tal. Em contrapartida, Purini, um dos organizadores da mostra, propunha para a mesma área um projeto unitário que estabelecesse uma relação clara entre formas arquitetônicas autônomas e sítios e funções diversos, relação obtida através de uma imagem única que retornasse à origem de Roma, encarregada de reproduzir o evento mítico 
do seu nascimento. ${ }^{\mathbf{5 8}}$ Entre esses dois extremos, restaria ainda assim a possibilidade de se recompor os fios que tecem a história de uma cidade, sem com isso transformá-la numa imagem unitária e autoritária, ou então dissolvê-la num arquipélago indiferenciado?

Em 1909, quando a modernização arquitetônica e urbana começava a adotar o receituário funcionalista (da Escola de Chicago a Berens ou Loos), Freud, numa de suas cinco conferências pronunciadas na Universidade de Clark, comparou o culto dos monumentos aos sintomas histéricos, que define como resíduos ou símbolos de certos elementos traumáticos — "símbolos comemorativos a bem dizer". Os monumentos com que ornamos nossas cidades seriam símbolos comemorativos do mesmo gênero. Uma tal fixação seria o análogo de um estado patológico. ${ }^{59}$

Comentando estas afirmações, Rickwert chama a atenção para o fato de que a cidade foi sempre tomada como símbolo mnemônico global, ou ao menos, como "um complexo estruturado de símbolos" e o conjunto de condutas em relação a eles não é obrigatoriamente repressivo. Representa, ao contrário do que pretende Freud, aquilo que ele mesmo consideraria uma relação "normal" com a situação, permitindo à emoção se descarregar em signos apropriados. Mas adverte, Freud permanece um patologista, como diz numa passagem da $4^{\mathrm{a}}$ conferência: "todo processo de desenvolvimento traz consigo o germe de uma disposição patológica". ${ }^{60}$

58. Catálogo da XVII Trienal — La cittá Immaginate, Milão: Electa, 1987; pp. 18 a 26 (Purini) e 40/41 (Eisenman).

59. Citado por Rickwert. "Le rituel de l'hystérie”, in L'Idée de la Ville, Champ Vallon: Seyssel, 1984, (pp. 46 a 55); pp. 46/47.

60. Ibid.; p. 47
Não é entretanto por aí que desejamos prosseguir neste Roteiro. Todavia não deixa de ser sintomática a coincidência da crítica de Freud aos monumentos, ou mesmo à ornamentação - que ele associa a comportamentos regressivos - com o ensaio de Loos O ornamento como delito. As matrizes sexuais, que em Freud são inevitáveis, também estão presentes em Loos ao explicar a simbologia dos ornamentos, porém para melhor desqualificá-los. Trata-se igualmente de compulsão sexual e neste caso associada a comportamentos perversos. Não se pode deixar de reconhecer a existência de uma patologia urbana, mas é bem provável que ela seja justamente a consequência do esquecimento sistemático de suas referências históricas, da dissolução, ou mesmo do "recalque", de suas lembranças. Por outro lado, a permanência dos monumentos não implica obrigatoriamente na inalterabilidade dos usos, dos significados ou dos comportamentos que gera.

Podemos procurar novamente em Gregotti subsídios para interpretar o fato, quando constata que a perda ou substituição de um dos dois termos - uso ou significado — na arquitetura, não faz com que ela deixe de ser o que é: "ou seja, é óbvia a existência de arquiteturas utilizáveis sem ser significantes, como também é óbvia a possibilidade de que um determinado monumento mantenha sua própria capacidade de ser significativo (ser, precisamente, monumento de uma época), ainda que tenha perdido a possibilidade de seu uso prático ou que este se mantenha desconhecido para nós, e isso sem perder a capacidade de emitir mensagens acerca de sua própria estrutura. Mais ainda, talvez tal incerteza de destinação aumente o fascínio do monumento e o mergulhe numa ambiguidade densa de estratificações signi- 
ficantes, enquanto referidas, com uma margem de arbitrariedade, a nosso horizonte de cultura e provenientes de um horizonte diverso".

Pode-se tratar, continua, tanto da atribuição de novos significados pelo grupo, quanto da ambiguidade ou polivalência inerente a toda obra de arte, permitindo diferentes interpretações. ${ }^{61}$

Embora no livro citado anteriormente, como também em sua Autobiografia Científica, Rossi atribua uma importância muito grande aos monumentos, chama a atenção para a oposição entre os elementos urbanos "vitais" e os que se poderia considerar "patológicos" - o exemplo dado é o das conservações ambientais que estariam em relação com os valores da cidade no tempo como se fossem "corpos embalsamados". ${ }^{22}$ Para ele, como para seu colega Gregotti, a cidade é "depositária de história": "a forma da cidade é sempre a forma de um tempo da cidade; e há muitos tempos na forma da cidade. É o que a faz ir mudando de rosto, ainda que certos elementos primários perdurem e sejam decisivos na sua formação e evolução". ${ }^{63} \mathrm{E}$ isto não só do ponto de vista físico, mas principalmente quanto à ideia que temos dela como síntese de uma série de valores. ${ }^{64}$

É entretanto esse imaginário coletivo que parece ter se esgotado faz tempo, de tal modo que, sob uma memória soterrada, não parecem subsistir mais do que fragmentos

61. Gregotti, op. cit.; pp. 180/181.

62. Rossi, op. cit.; p. 102.

63. Ibid., pp. 104/105.

64. Ibid., p. 222. de uma história desconexa, recapitulada à força pela retórica dos poderes constituídos, no intuito de fazer acreditar na existência de uma identidade há muito perdida. Nesse contexto, o preservacionismo, em geral oficial, está cada vez menos ligado ao valor de atualidade dos monumentos e, na maior parte das vezes, nem mesmo está vinculado a valores artísticos e/ou históricos, resguardando apenas o valor de antiguidade. ${ }^{65}$ Isto é, como um documento que pode se transformar ele próprio em valor comemorativo: cultua-se o antigo pela sua antiguidade. Não há dúvida de que, como objetos celebrativos de datas memoráveis de uma história, no mais das vezes inconsciente, mas que poderiam aflorar como marcos de referência iluminando o presente, dando-lhe sentido, os monumentos estão totalmente "desativados", emudecidos em meio ao mundo desencantado dos tempos modernos. Ao invés de forças ativas, como "iluminações profanas" ${ }^{66}$ vindas do passado para animar o presente, não passam de acenos nostálgicos a estimular comportamentos regressivos de fuga do presente - no máximo, fatos comemorativos de uma história morta.

É aqui que se põe a pertinência ou não de uma estratégia de revalorização dos monumentos, de reconhecimento ou criação de fatos urbanos primários, simbólicos, pregnantes na vida e na imagem de uma determinada cidade, tudo isso com o futuro em mente. A degradação da experiência em vivências rotineiras teria o mérito de despertar a consciência, dissolvendo a dimensão aurática que acompanha o culto dos monumentos (pelo seu valor

65. A terminologia é de Riegl. Scritti sulla tutela e il restauro, Palermo Renzo Manzzone ed., 1982

66. Expressão utilizada na acepção consagrada por W. Benjamin. 
celebrativo ou de antiguidade), em nome de uma intervenção voluntária. Mas a quem caberia a iniciativa? E até onde um tal propósito só se sustentaria se baseado num sentimento geral que pode apenas provir de uma "reorganização da vida coletiva", como já observava Giedion, em 43, diante, de um lado, do caráter predatório da guerra, de outro, da pseudomonumentalidade nazifascista. Foi quando publicou, juntamente com Sert e Leger, Nove pontos a propósito da monumentalidade: a monumentalidade, uma necessidade humana, em que propunha a construção de monumentos como expressão das necessidades culturais mais elevadas do homem, testemunhos históricos, ligações entre o passado e o futuro, e símbolos da força coletiva de um povo.

"Os períodos que viveram sem perspectivas de futuro foram incapazes de criar monumentos duráveis". Em parte era o que, conforme acreditavam, vinha acontecendo e contra o que se opunha a necessidade de uma planificação urbana que deixasse espaços livres, propícios à implantação de construções que não seriam apenas funcionais, mas teriam o poder de "elevar a alma". Lê-se em um outro texto de Giedion de 44: "a multidão quer que se exprima a sua necessidade de luxo, de alegria, de exaltação exterior". Esses espaços tornariam possíveis "novos centros de vida coletiva". Mas como realizar isso? O sentido da monumentalidade teria sido perdido juntamente com o de uma “vida comunitária ativa”. Seria portanto necessário uma reformulação concomitante das cidades e da vida coletiva. O círculo parece fechar-se. É quando Giedion apela para o Estado - não o totalitário, de boa parte da Europa, mas o keynesiano, “onde a produção de bens excedentes que não fossem destinados ao uso quotidiano viabilizaria a construção de centros de vida coletiva". E conclui o texto com o seguinte apelo: "não seria possível reanimar a economia pelo interior, destinando uma parte das despesas" à criação de lugares de agrupamento em que o homem retomaria consciência das necessidades enterradas em sua alma e que, em nossos dias, estão atrofiadas?"67

Ora, é em parte o que vem ocorrendo por iniciativa dos Estados capitalistas modernos, investindo em obras monumentais justificadas pela ideologia da criação de lugares públicos, mas nem por isso restaurados. ${ }^{68}$ Funcionam contudo como grandes vitrines publicitárias (veja-se em Barcelona, as iniciativas urbanas e arquitetônicas tomadas em razão dos Jogos Olímpicos de 1992) que despertam, à sua maneira, o espírito cívico, o orgulho nacional, mas não obrigatoriamente motivam para a vida pública. Os ideais republicanos e societários têm pouco a ver com essa pseudomonumentalidade midiática, produzida pelos Estados capitalistas avançados (ou, em forma de arremedo, nos países periféricos, como o nosso Memorial da América Latina), embora tais lugares possam desencadear comportamentos não planejados, que muitas vezes passam a ter vida própria, independente das intenções que estavam na sua origem.

Voltando ao referido acima acerca das pretensas estratégias de sentido dos poderes constituídos: não passam de fato, em geral, de "estratégias asseguradoras" diante da ameaça do desmoronamento das crenças nos grandes valores tradicionais, como adverte um estudioso das po-

67. Op. cit.; p. 60.

68. Tive oportunidade de analisar esse fenômeno na Paris de Mitterrand em "Os dois lados da arquitetura francesa pós-Beaubourg", in O Lugar da Arquitetura depois dos Modernos cit. 
líticas patrimoniais, Henri-Pierre Jeudy. ${ }^{69}$ Como último recurso de animação sociocultural constróem-se verdadeiros teatros da memória. Na verdade, desencadeia-se uma lógica da evocação que mais funciona como uma antimemória coletiva: a preservação e restauração de muitos dos monumentos passados, em especial a "limpeza" dos velhos centros urbanos com seus edifícios públicos, na maior parte das vezes apenas esconde as marcas do tempo e, reprimindo suas metamorfoses, acarreta uma redução ao idêntico, uma espécie de "ordem branca da memória". Segundo o autor, querer determinar a forma de apreensão do que é "próprio" a um certo lugar é uma maneira de limitar a variação destes modos de apropriação. "Ao mesmo tempo, um tal empreendimento de asseguramento cultural impõe uma verdadeira configuração da ordem." É certo que muitos políticos parecem estar convencidos dos poderes regenerativos da cultura, mas "essa união de um ideal securitário e da renovação de uma memória coletiva urbana está longe de ocorrer ao acaso: ela faz eco ao projeto de forjar uma nova harmonia dos vínculos sociais. A cultura vem então em socorro da política para atenuar e dissimular o cumprimento de uma lógica securitária que, sob muitos pontos de vista, poderia parecer totalitária."70

Por outro lado, continua Jeudy, se uma tal gestão da cidade pode levar a um sistema de signos petrificados, a uma simulação teatral da vida urbana inexistente, pode também, quem sabe, representar algo como uma "multiplicação cênica”, a seu ver, capaz de gerar transformações culturais - uma recuperação do passado tendo em vista

69. Cf. especialmente Jeudy. Memórias do Social, Rio de Janeiro: Forense Universitária, 1990.

70. Ibid.; (pp. 107 a 118); p.108. uma verdadeira "ação prospectiva cultural polivalente". ${ }^{71}$ Mas para tanto é preciso passar para o outro lado, evitar a preservação que supervaloriza a monumentalidade, substituindo-a por uma que estabeleça contradições ativas entre conservação e memória, que articule o patrimônio passado ao futuro, que volte ao simbólico como antecena de uma história social, que se atenha tanto ao que há de residual na tradição cultural de um povo quanto à polissemia dos objetos culturais. Ou seja, um processo de "anamnese" coletiva que revele os traços culturais autênticos, ou mesmo uma identidade cultural passada, mas numa interpretação ativa por parte do próprio grupo social, e que seja portanto prospectiva e transcenda o princípio identitário que congela as diferenças.

Segundo esse ambicioso programa de "etnologia regional", estaria em causa uma recuperação global da sociedade, impulsionada pelo patrimônio, que funcionaria como “operador social”. Jeudy está pensando sobretudo nos ecomuseus ou museus comunitários, onde a gestão patrimonial já representaria um capítulo novo nas relações sociais, quando então uma primeira instância crítica dos vínculos tradicionais entre saber e poder, através de uma retroprojeção que desestruture o passado e faça retornar o que estava oculto, se encarregaria de fundar um "imaginário histórico" aberto para o futuro. Em princípio algo diverso da "historicização" desenvolvida pelas políticas culturais oficiais, que manipulam a memória coletiva, álibi com o qual fabricam o espelho onde se reflete seu próprio poder. - “É através do imperativo cultural que podem então se efetivar todas as simulações de restituição do social e das questões políticas. Se tudo se torna ou

71. Ibid.; pp. 114/115. 
já é objeto de cultura, as contradições que aparecem nas políticas culturais são de imediato neutralizadas". ${ }^{72}$

Como escapar ao perigo das imagens petrificadas, evitar a simples reprodução conservadora, resistir à tentação da massificação turística? Como afirmar as diferenças sem incorrer na formação de guetos ou na manutenção dos valores como forma de polícia cultural? Tais questões entretanto extravasam o âmbito do nosso roteiro. Refiro-me ao problema mais amplo da gestão da cultura e à correspondente estetização da memória, do qual a criação de espaços públicos urbanos é apenas um aspecto, talvez o mais evidente dadas as alegações ideológicas a que se presta para justificar as grandes intervenções urbanas.

\section{Uma "modesta" autonomia}

Uma tal avaliação, entretanto, pode deslocar a questão arquitetônico-urbanística dos monumentos - enquanto elementos ou sinais privilegiados de uma história a ser reativada - para a tradição vernacular, para o passado simples, para a memória prosaica, para o "feio e ordinário" de que falava Robert Venturi. O próprio Rossi chega a reconhecer que, para algumas formações urbanas, as áreas residenciais funcionam como elementos primários, a imagem da cidade portanto nem sempre dependendo de fatos únicos e exemplares. No fundo, são estratégias complementares. ${ }^{73}$ Frampton, por exemplo, faz a crítica ao que considera o populismo de Venturi, à pequena escala,

\section{Ibid.; p. 136.}

73. Como procurei sugerir no estudo citado sobre Paris. ou escala doméstica, à concentração nos detalhes, própria à concepção de uma "arquitetura kitsch e de encantamento". A tudo isso opõe uma arquitetura de resistência, ora apresentada como monumental ${ }^{74}$, ora como regionalista. ${ }^{75}$ Esta última, entretanto, não sofreria das limitações apontadas na obra de seu colega, pois alega ter em mente um "regionalismo crítico", algo como uma consciência arquitetônica que não daria trégua ao patrulhamento conservador característico do "populismo" e do "regionalismo sentimental".

Detenhamo-nos um pouco nesse programa de uma arquitetura de "retaguarda", como a chama Frampton, e que se inspira no texto de Alexis Tzonis e Liliane Lefaivre - "The Grid in the Pathway" (1981) - , no qual é proposto um "regionalismo crítico como a única ponte por onde deve passar no futuro uma arquitetura humanista". Para tanto evocam uma tradição que viria dos anos 20 , em especial de Lewis Mumford que, desde Stricks and Stones, a Study of American Architecture and Civilization (1924), opõe a interação existente entre a cultura popular e seu lugar de origem, às construções da "nova nobreza financeira" americana, com suas "fachadas imperiais". Em 41, numa série de conferências sobre The South in Architecture, Mumford ser ainda mais enfático quanto aos interesses materiais que moldavam a arquitetura americana. Na Europa, o destaque dos autores vai para o texto de Stirling de 1957, New Regionalism - uma forma de reação à nova monumentalidade palladiana, bem como à da

74. Cf. Frampton, artigo citado.

75. Cf. “Towards a Critical Regionalism”, in Foster, Hal (org.). The anti-aesthetic, Essays on Posmodern culture, Bay Press, Washington, 1983 (pp. 16 a 30). 
arquitetura internacional - e para os "realistas" italianos, especialmente os arquitetos vinculados à INA-casa e o grupo BBPR. Finalmente, Kenzo Tange da primeira fase, que propunha uma arquitetura "vitalista" ${ }^{76}$

Tanto para Tzonis e Lefaivre, como para Frampton, o referido programa representa um esforço paradoxal de retorno às fontes sem deixar de ser moderno. ${ }^{77}$ Segundo Frampton, a otimização da técnica restringiria as possibilidades de se criar uma "forma urbana significativa". Assim, os imperativos da produção seriam responsáveis a um só tempo por uma arquitetura high tech e por fachadas compensatórias, encobrindo com tais carcaças a realidade desencantada do sistema universal. Nessa "burolandschaft city-scape" as culturas locais estariam inteiramente submersas por uma civilização mundial padronizada. Diante disso, caberia ao Regionalismo Crítico uma dupla mediação: em primeiro lugar, "deve desconstruir todo o espectro da cultura mundial em seus inevitáveis componentes" - não em nome do ecletismo e da valorização do exótico, mas em nome de uma "revitalização da expressividade de uma sociedade enervada"; em segundo lugar, neste mesmo espírito de oposição ao sistema internacional, deveria proceder de modo a impor limites à otimização tecnológica industrial ou pós-industrial. Não seria o caso de defender formas autóctones, mas de articular um diálogo produtivo entre dois universos culturais, evitando a saída fácil e postiça que seria a combinação heteróclita de elementos high tech e de soluções artesanais ou folclóricas. Em princípio, o programa de Frampton não

76. Cf. "El regionalismo critico y la arquitectura espaxola actual", in A\&V 3, Madri, 1985 (pp. 4 a 19) - pp. 7/8 e notas 9 e 10.

77. Cf. Frampton, in Ibid.; p. 17. faz concessões às aparências, como ocorre a seu ver com a arquitetura pós-moderna, mas quer ao contrário uma arquitetura concebida como "forma-lugar", onde seja igualmente evidente a intenção política de resistência.

Estamos novamente em presença de um pensamento arquitetônico reduzido pelas teorias de Heidegger, que nada tem a ver, como dissemos, com o lugar enquanto espaço da vida pública. Neste mesmo programa voltamos a reencontrar as ideias de Hannah Arendt acerca da vida na cidade como fator indispensável na geração do poder político. Dessa conjunção resulta uma curiosa conversão da "presença" ontológica do lugar heideggeriano, que assume a dimensão de "modo público", àquilo que Arendt chamou "o espaço da aparência humana"78.

Contra uma atitude que qualifica de reacionária como a de Venturi, ao afirmar, em 1966, que os americanos não necessitam de praças pois ficam em casa vendo televisão, daí o caráter supérfluo e inócuo de uma replanificação da cidade para uma população que perdeu o senso da vida urbana - , Frampton advoga a causa de uma arquitetura que apresente "densidade" e tenha "ressonância expressiva”. Com isto imagina uma cidade sem dúvida populacionalmente densa, mas na qual se manifeste antes de tudo uma densidade cultural que possa, nas condições atuais, liberar o usuário para novas experiências. Vistas as coisas desta perspectiva, a "provisão de formas-lugares" torna-se essencial para o que entende ser uma prática crítica, estendendo-se dos blocos perimétricos até às galerias, pátios, trios, labirintos, etc. Frampton sabe muito bem que "muitas dessas instâncias tornaram-se hoje

78. Cf. Ibid.; pp. $24 / 25$ e "The status of a man and the status of his objects", in AD 7/8, 1982 (pp. 6 a 19). 
meros veículos para acomodar pseudos reinos públicos (como nas recentes megaestruturas de residências, hotéis e shoppings)", mas acredita que "não se pode nunca eliminar em tais instâncias o potencial político e de resistência das formas-lugares". ${ }^{79}$

Como estamos vendo, o raciocínio é francamente citadino, contra portanto a ideologia das "comunidades dispersas" ou de "um domínio urbano não localizado" segundo seu autor, "slogans visando gerir a ausência de um real domínio público na moderna motopia (ou utopia motorizada)". De outro lado, de novo na esteira de Heidegger e se apoiando no arquiteto suíço-italiano Mario Botta, introduz uma dimensão que ultrapassa a questão sociocultural meramente urbana implicada na "construção do lugar", para incluir níveis geológicos e arqueológicos em seu quadro, de modo que a forma construída incarne "a pré-história do lugar". ${ }^{80}$ - Ou seja, a "densidade expressiva" parece ganhar uma conotação ontológica. Mas até mesmo o autor se pergunta pelo cabimento dessa formulação metafísica do problema, tanto é assim que em seguida atem-se apenas à necessidade de um "domínio delimitado" para definir uma arquitetura de resistência dentro das megalópoles são portanto "atributos setoriais da densidade urbana" que podem gerar novos fatos sociais arquitetônicos que se oponham à extensão sem fim das cidades modernas. ${ }^{81}$

Tendo em vista uma arquitetura adequada a um tal projeto, o arquiteto inglês menciona as condições topo-

79. Cf. último capítulo de História crítica..

80. "Towards a Critical Regionalism", in op. cit.; pp. 26/27.

81. Ibid.; p. 25. gráficas, o clima, a luz, o contexto, mas é antes de tudo nas componentes tectônicas e táteis (nos fatores estruturais, formais e não cenográficos, e sensitivos mais do que óticos) que residiria a autonomia ou a potencialidade crítica semelhante arquitetura. Nestes termos, encerra o ensaio sobre o Regionalismo Crítico com a seguinte afirmação: "O tátil e o tectônico juntos têm a capacidade de transcender em muito a mera aparência da técnica, no mesmo sentido em que a forma-lugar tem o potencial de fazer frente ao massacre incessante da modernização global". ${ }^{2}$

Fica claro que não se trata de uma arquitetura figurativa, trabalhando com signos de decodificação imediata - como para o Venturi de Aprendendo com Las Vegas - , mas de uma expressividade da forma mesma enquanto forma-lugar. É também o oposto do ecletismo historicista que, segundo Frampton, patrocinaria uma iconografia consumista disfarçada de cultura ${ }^{83}$ Não é uma política da construção stricto sensu que está sendo visada, mas uma poética que resista à empreitada internacional da técnica. Ora, apesar das consequências políticas reclamadas por uma tal estratégia poética, a ausência de referências históricas mais precisas pode desembocar numa arquitetura de evocação sentimental, numa arquitetura que reforça mais o imaginário mítico, do que a resistência ativa e prospectiva. É ao que uma leitura de Heidegger ao pé da letra sem dúvida conduziria, mas não é esta entretanto a intenção de Frampton. Tanto parece ser assim que denuncia reiteradamente o atual retorno, aliás tardio, ao pathos ideológico da cultura dita popular. - É o que transparece,

82. Ibid.; p. 29

83. In "El regionalismo critico: arquitectura moderna e identidad cultural", A\&V cit. (pp. 20 a 25); p. 20. 
por exemplo, numa das tantas vezes em que tenta precisar o que seja um tal programa arquitetônico:

“O termo Regionalismo Crítico não pretende designar o vernáculo tal como se produziu espontaneamente pela interação de clima, cultura, mito e artesanato, mas identificar aquelas escolas regionais recentes, cujo propósito foi representar e servir com um sentido crítico, as áreas limitadas em que estão assentadas. Tal regionalismo depende, por definição, da conexão entre a consciência política de uma sociedade e a profissão."

Mas no entanto reconhece: "Tal conjunção entre o político e o cultural é difícil alcançar na sociedade do capitalismo tardio." Ou seja, "onde faltam as condições de uma política e uma cultura consistentes, é difícil formular uma estratégia criativa."\$4

Frampton assim mesmo acredita que o regionalismo ainda pode florescer dentro de "descontinuidades culturais que se articulam de forma inesperada nos continentes da Europa e América" - manifestações fronteiriças que se podem caracterizar, segundo Moles como "interstícios de liberdade". Nesse mesmo artigo enumera uma série de experiências que lograram êxito, ao encontrar soluções arquitetônicas contemporâneas que ao mesmo tempo foram capazes de preservar as referências locais, uma das mais significativas teria sido a do regionalismo catalão, em especial do grupo encabeçado por Bohigas - "um exemplo da natureza essencialmente híbrida de uma cultura moderna autêntica" - e anunciada no livro deste, de 1951, Possibilidades de uma arquitectura bar-

84. Cf. Ibid. celonesa. Por um lado, estavam obrigados a restabelecer os valores e procedimentos racionalistas e antifascistas da ala espanhola de pré-guerra dos CIAM, de outro, tinham a responsabilidade política de evocar um regionalismo realista que fosse acessível ao povo; já as últimas obras do grupo (MBM) parecem ter menos consistência, oscilando entre um preciosismo um tanto inconsequente e uma construção retraída - "sente-se com pesar que se aproxima o fim de uma época heroica". ${ }^{85} \mathrm{Na}$ recapitulação feita por Frampton, são também incluídos os realistas italianos, de Gardella a Gregotti; Alvaro Siza, em Portugal; Barragán, no México; até Reidy e o primeiro Niemeyer (dos anos 40) comparecem nesta listagem que inclui muitos outros arquitetos, detendo-se nos representantes mais recentes do regionalismo crítico, como Mario Botta, na Suíça, ou Tadao Ando, no Japão. Este último, sempre segundo Frampton, dentre os japoneses é um dos arquitetos que mais consciência tem da tensão entre a modernização universal e a idiossincrasia de uma cultura enraizada, como a do Japão. Veja-se, por exemplo o que ele mesmo diz em A moderna arquitetura autóctone em direção à universalidade: "Creio que posso dizer que o método que escolhi consiste em aplicar o vocabulário e as técnicas desenvolvidas pelo Movimento Moderno, aberto e universalista, a uma esfera fechada, com modos de vida individuais e diferenças regionais". Botta, por seu lado, combina as lições dos diversos métodos racionalistas extraídos do exterior com uma misteriosa capacidade (resultante de seu aprendizado com Scarpa) para o "enriquecimento artesanal da forma e do espaço"; de outro

85. Frampton, K. Martorell, Bohigas, Mackay, 30 años de arquitectura 1954-1984, Barcelona: Xarait Ediciones, 1985; p.25. 
lado, tem a convicção de que a perda da cidade histórica só pode ser compensada Building the site - criando reinos micro-urbanos, ilustrados exemplarmente no colégio de Morbio Inferiore - "compensação cultural pela perda urbanística em Chiasso, a cidade mais próxima”. Uma mesma preocupação em instaurar um contexto próprio semiurbano como forma de revitalização dos padrões citadinos atuais, Frampton vai reencontrar (de acordo com monografia publicada recentemente) num arquiteto muito diverso e tido como expressão máxima da arquitetura abstrata e formalista new modern, Richard Meyer, reafirmando, ainda uma vez, sua ênfase nas componentes tectônicas da forma tanto quanto sua evidente inclinação pelas tendências contemporâneas que, de alguma maneira, se ligam à tradição moderna racionalista. ${ }^{86}$

Por mais que variem as soluções, de Giedion a Frampton, passando pelo grupo italiano Tendenza, dos monumentos às áreas residenciais, de conjuntos de edifícios a prédios isolados, parece que um ponto comum os une: "a estratégia subversiva de enclave urbano". ${ }^{87}$ Contra uma paisagem urbana comandada pela lógica do Mesmo, enquadrada por uma civilização internacional dominada pela compulsão programada do consumo: uma arquitetura do lugar. Se for mantida a perspectiva urbana e se não se perder a consciência de que se trata de uma sociedade de massa, talvez se possa escapar simultaneamente à

86. Richard Meyer, Buildings and Projects, 1979-1989, London: Academy Editions; and New York: St. Martin’s Press, 1990.

87. A expressão é de Frampton na História crítica...; p. 300. tirania da intimidade e à ideologia comunitária, ou, o que vem a dar no mesmo, à formação de guetos. Os autores e tendências que repertoriamos pelo menos alegam que se trata antes de tudo de estimular a proliferação do urbano a partir dele mesmo - nem implosão, nem expansão, mas reenervamento, como diria Frampton. 


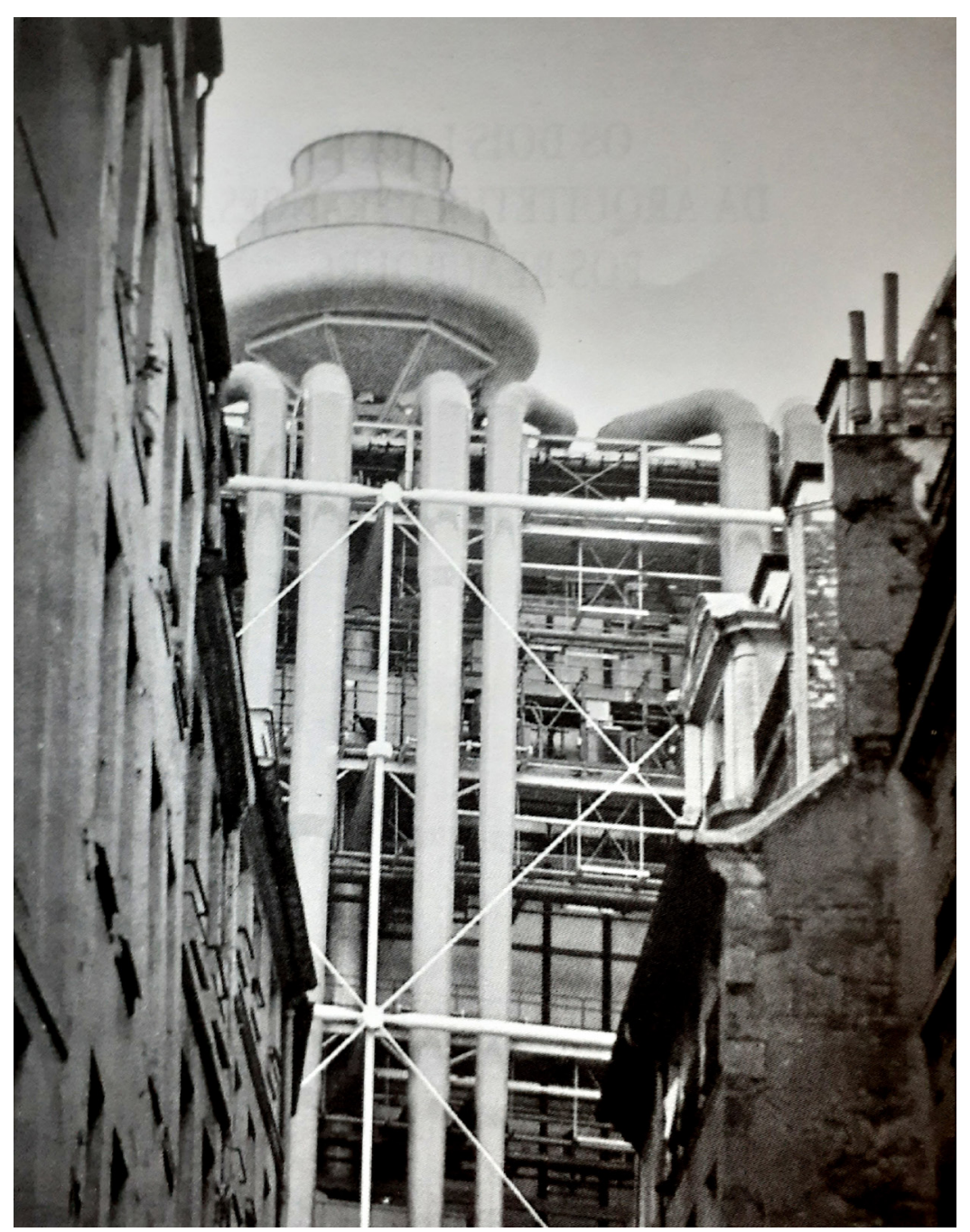

Renzo Piano e Richard Rogers, Centro Georges Pompidou (Beaubourg), 1974-79

\section{Cultura da cidade, animação sem frase $^{1}$}

Assistimos hoje em dia a uma verdadeira avalanche discursiva e projetual que tomou de assalto não apenas a imaginação dos teóricos, mas o que ainda teimamos em chamar de intervenção urbana. Trata-se com efeito de uma volta à cidade de um tipo muito especial. É certo que uma nova fatalidade nos empurra para o centro explosivo da cena urbana, mas não é tão certo assim, como se pretende, que repetimos ainda com maior intensidade a experiência do "homem das multidões", descrita por Allan Poe e elevada por Baudelaire à condição de alegoria. Foram-se os tempos de espíritos fortes em esgrima heroica com as primeiras manifestações da fantasmagoria que começava a assombrar as metrópoles do capital. Em nosso fim de século lidamos com um outro personagem, desgovernado por um Eu cuja falta de substância se espelha na presteza com que se deixa fascinar pelo espetáculo do caos

1. Trata-se de um texto no qual tento fundir vários textos e conferências (19931995), especialmente intervenções provocadas pela polêmica em torno da minha intervenção na Bienal de Arquitetura de 1993: "Urbanismo em fim de linha". Como roteiro básico, sigo principalmente o ensaio "Cultura da Cidade: animação sem frase" (publicado na Revista do Patrimônio nº 24 ) e a comunicação que apresentei no Seminário Cidade e Imaginação, promovido pela PROURB, FAU/UFRJ, sobre “Da Cidade como lugar à cidade como não lugar”, em novembro de 1994 (reproduzida parcialmente na A.U. n58, 1995), incorporo também algumas análises e vários exemplos de conferências pronunciadas no Brasil e no estrangeiro sobre o papel dos Novos Museus e Centros Culturais nas novas estratégias urbanas. Mantenho a versão de Urbanismo em fim de linha, São Paulo: EDUSP, 1997. 
urbano - no mundo da "frivolidade", o "heroísmo da vida moderna" só poderia retornar como um blefe.

Compassada com este estado de coisas, a nova ensaística da cidade redescober ta vem mobilizando um aparato conceitual muito up to date, mal escondendo em sua alegada subversão um convívio estetizante com as formas mais extremadas da alienação contemporânea. De fato, quanto mais nos sentimos mutilados por esta modalidade atual de vivência que ainda se quer urbana, tanto mais nos deixamos persuadir de que é neste cenário desolador que se encontra à nossa disposição uma fonte única de vida e imaginação. Por isso vou me esforçar por levantar um pouco o véu que encobre esta situação - tarefa tão mais difícil quanto, como sabemos, a realidade é hoje sua própria ideologia.

Comecemos tentando entender um pouco o que seja esse novo sentimento urbano de que estaríamos em princípio investidos, a começar pela interversão contextualista do Movimento Moderno, ou que nome se dê ao pensamento projetual marcadamente defensivo a que se resumiram as duas últimas décadas (até meados dos anos 80) ao longo das quais assistimos (e sofremos na periferia) um gigantesco ajuste modernizante e conservador do capitalismo central.

\section{A Cultura da Cidade}

Até bem pouco tempo, a abordagem da cidade, tanto no plano prático das intervenções urbanas, quanto no âmbito do discurso teórico específico, se dava prioritariamente em termos de racionalidade, funcionalidade, salubridade, eficiência, ordenação das funções: em suma, falava-se e agia-se em nome da sociedade no seu conjunto, pelo menos era assim na imaginação a um tempo política e técnica das pessoas concernidas. Nos dias atuais, tudo parece obedecer ao princípio máximo da flexibilização. Daí o primado do desenho - do traçado urbano ao design dos microespaços - e do tipo de representação simbólica que lhe corresponde. Assim, fala-se cada vez menos em planejamento da cidade, que deste modo estaria obrigada a obedecer a um modelo estável de otimização do seu funcionamento, e cada vez mais, em requalificação, mas em termos tais que a ênfase deixa de ser predominantemente técnica para recair no vasto domínio passe partout do "cultural".

Essa mudança de registro por certo não é de agora (como veremos mais adiante), mas em pouco tempo acabou se convertendo no ponto de vista hegemônico entre os especialistas. Mas especialistas em quê, exatamente? Endereçada a algum veterano do período anterior, a dúvida não teria cabimento, recebendo uma resposta inequivocamente profissional, pautada pelos preceitos modernos de competência, adquirida nas escolas-padrão, também elas planejadas segundo o mesmo receituário. Mas isso é coisa do tempo em que arquitetura era apenas assunto de prancheta e canteiro. Com a volta à cidade nos termos em que vem ocorrendo, essa disciplina ruiu, extravasando o círculo da dedicação profissional exclusiva. Atualmente a cidade foi tomada de assalto por uma legião de especialistas em outras coisas. Bom sinal, no mínimo de que a arquitetura, e em particular a arquitetura da cidade, tornou-se referência obrigatória na interpretação da sociedade contemporânea. Nem tanto, se lembrarmos que o assim chamado "urbano" transformou-se numa terra de ninguém — aliás em todos os sentidos. Virou sobretudo matéria de 
discurso: foco de um fraseado inesgotável e para todos os gostos, as falas sobre a cidade funcionam como se fossem o prolongamento metafórico de um discurso material da própria cidade, ela mesma um Texto, e tudo o mais que daí se segue. Na verdade, trata-se de uma virada objetiva e não uma mera mudança de modelos ideológicos. Guinada responsável pela naturalidade com que não-especialistas (entre os quais me incluo) se veem estimulados a falar de um assunto que em princípio não lhes competia; tanto quanto, num movimento inverso, os verdadeiros profissionais, a adotar em massa, e quase sem se dar muito conta, a nova língua franca que é o discurso da cidade - fatos incluídos, porque se trata de atos de fala performativos, pois a cidade também passou a ser aquilo que se diz dela. Aqui o decisivo: a favor ou contra, todos falam a mesma língua, teóricos e gestores urbanos em geral. No que se segue, gostaria de relembrar não só como se deu essa reviravolta, mas também esse nivelamento terminológico e conceitual, indiferente às melhores intenções críticas. ${ }^{2}$

Portanto, quem hoje em dia mexe com a arquitetura da cidade e demais tópicos adjacentes, cuida menos de uma especialidade nova e batizada de transdisciplinar do que possivelmente do capítulo central do debate contemporâneo - um campo de forças técnicas, artísticas e políticas marcado pela ascendência inconteste do supracitado "cultural". No momento em que as cidades passaram

2. Por isso me animei, nas recapitulações e balanços, a transcrever e adaptar trechos de outras exposições não tão antigas assim, uma maneira provisória de tomar distância, na esperança de nalgum momento encontrar o ponto arquimediano de um novo enfoque, desta vez ainda mais recuado... (Retomo, em especial, alguns tópicos do ensaio sobre "A ideologia do lugar público na Arquitetura Contemporânea", publicado no livro O Lugar da Arquitetura depois dos Modernos - reproduzido aqui neste e-book — ; além das conferências a que aludi.). a ser encaradas como um repertório de símbolos, tudo virou cultura. ${ }^{3}$ Para ser mais específico, patrimônio a ser preservado. Nove em cada dez secretários de cultura são desta opinião, a saber, a preservação do patrimônio é a prioridade número um. E eles têm involuntariamente razão, desde que invertamos o raciocínio: o patrimonialismo (se for possível falar assim) não é apenas a forma exacerbada (e rotineiramente mecanizada) assumida pela generalização da atenção privilegiada que parece gozar tudo que consegue se apresentar como dotado de significado cultural, mas é antes a mais acabada expressão de tal generalização avassaladora, e isto, por ser o seu foco ori-

3. Como se sabe, este teorema de demonstração tão complicada - "tudo virou cultura" - constitui hoje o principal lugar-comum dos Estudos Culturais. Não saberia a quem atribuir a paternidade dele. A bibliografia especializada costuma vincular Fredric Jameson às primeiras formulações incisivas desse tópico. Ao que parece a estreia do tema em seus escritos remonta a um ensaio de 1979, publicado na Social Text ("Reification and Utopia in Mass Culture", recentemente em tradução brasileira, in Crítica Marxista, $\mathrm{n}^{\circ} 1$, São Paulo, Brasiliense, 1994), no qual apresenta a cultura como o elemento específico da sociedade de consumo, saturada de signos e imagens numa escala jamais vista. Ideia confessadamente adaptada de Guy Debord (A Sociedade do Espetáculo) e com clara influência do Baudrillard daquele período, também um dos primeiros a elevar a junção de mercadoria e signo à condição de categoria básica do capitalismo avançado. Entretanto, enquanto Baudrillard se encaminhará (anos 80) para uma explicação estritamente semiológica - uma reduplicação infinita de signos regendo de tal modo o social, de sorte a torná-lo, em última instância, "cultural" - Jameson, de seu lado, não deixará de procurar uma interpretação materialista para tamanha ênfase na dimensão cultural, cuja evidência não nega (cf. a respeito "Postmodernism: or the Cultural Logic of Late Capitalism" in New Left Review, 146, 1984; e, de 1985: "Periodizando os anos 60", in Heloisa Buarque de Hollanda (org.), Pós-Modernismo e Política, Rio de Janeiro: Rocco, 1991). Tendo divulgado entre nós este texto em que Jameson data dos anos 60 a gênese desse processo de "culturalização", Heloisa Buarque de Hollanda, ao apresentar o número 23 da Revista do Patrimônio, retorna àquele ensaio para explicar a mudança de enfoque sobre a cidade (a que estou também me referindo), resultante, segundo a Autora, de uma "simbiose entre cidade e cultura" que viria se processando no último período de metamorfose da sociedade de consumo. Voltaremos ao mesmo escrito mais adiante, embora para extrair consequências um pouco diversas. (Para um resumo recente das idas e vindas e filiações no que tange o referido teorema segundo o qual tudo transformou-se em cultura, ver Mike Featherstone, Cultura de Consumo e Pós-Modernismo, São Paulo: Studio Nobel, 1995.) 
ginal. Na medida mesma em que as grandes aglomerações urbanas acabaram reunindo o maior acervo de "bens culturais", aos quais se somam enormes estoques de valores e tradições, elas foram se tornando por isso mesmo a arena por excelência das novas estratégias a um tempo políticas e culturais. Palco onde se apresentam os mais desenvoltos Movimentos Sociais, novos e velhos, onde as minorias também lutam por uma maior visibilidade e reconhecimento de seu direito à diferença, a cidade a rigor se encontra no centro dos irresistivelmente proliferantes estudos culturais, ainda que ela mesma não compareça como objeto ostensivo. Ou melhor, por isso mesmo: a referida mudança de registro nos debates (e respectivas providências administrativas) não só precedeu a onda culturalizante em que acabou submergindo toda a sociedade contemporânea como a bem dizer a vem impulsionando desde a origem, na qualidade de cena originária. - Mais uma razão para se empreender o esforço crítico assinalado acima, aliás redobrado.

\section{A "era da cultura"}

Antes de recapitularmos essa volta à cidade a que estamos nos referindo, talvez caiba um primeiro sobrevoo. Em breves traços: a que corresponde este novo estágio da sociedade capitalista contemporânea a que alguns estão chamando de "era da cultura"?

De fato, nunca se falou tanto em Cultura e seus derivados como nos dias de hoje. É bem possível que só em inglês - a língua geral do planeta -, o número de revistas especializadas em questões ditas culturais já tenha atingido cifras inflacionárias. A tradicional casa editora Routledge lança atualmente uma média de dois a três títulos por semana sobre o assunto. Sem falar na ciranda internacional de colóquios e similares. Mau negócio é que não há de ser o eixo em torno do qual parece girar a tal Era da Cultura em que supostamente vivemos. Uma idade em que a noção de Cultura se expandiu a ponto de abarcar praticamente todas as dimensões da vida social. Não há experiência ou artefato que não se apresente investido de um significado cultural qualquer, que por isso mesmo passa por instância definidora de sua natureza. Tudo é passível de associações simbólicas, possui referências a práticas e tradições locais - valores esquecidos e reativados por essa nova voga cultural, que parece querer a todo custo devolver aos cidadãos cada vez mais diminuídos nos seus direitos, materialmente aviltados, e socialmente divididos, sua "identidade" (ou algo similar que o console de um esbulho cotidiano), mediante o reconhecimento de suas diferenças "imateriais".

Tudo se passa como se o reino do espírito triunfasse finalmente sobre a matéria, empurrando um mundo dividido na direção pacificada de uma reconciliação global, ao menos no plano da imaterialidade, a começar pela dimensão predominante video-eletrônica. Trata-se obviamente de políticas compensatórias, visando a "inclusão" cultural dos excluídos social e economicamente. Ao mesmo tempo, uma tal acumulação de "capital simbólico" redunda numa expansão das instituições e num retorno material nada desprezível para os produtores culturais - sejam eles Estados ou empresas (como dizia Jack Lang, ex-ministro francês dos Affaires Culturelles: "a cultura é o nosso petróleo"). Os megaeventos se sucedem cá e lá. Não se consomem mais obras, mas "pacotes", destinados a ativar o turismo cultural, inclusive sem que as pessoas 
sejam obrigadas a se deslocar, pois mostras e cursos passaram a ser itinerantes, a se reproduzir tecnicamente tal qual o cinema, como ocorre aliás com quase tudo, desde que adequadamente planejado para se transformar em imagem eletrônica.

E não é só do ponto de vista dos interesses financeiros que se deve avaliar o inchaço do mercado cultural (das fine arts aos exotismos folclóricos); no estágio do capitalismo mundializado em que nos encontramos, a "culturalização" de todas as formas de intercâmbio - social, político, econômico - faz parte das estratégias governamentais, em todos os níveis, à direita e à esquerda. A unanimidade é tal que se torna totalmente supérflua qualquer alegação ideológica - ça va de soi, sans phrase... Mas por que então - podemos voltar a nos perguntar - toda essa produção discursiva, por que nunca se falou tanto de cultura? Justamente. Mau sinal. Os discursos desses novos intelectuais - experts nos mecanismos sutis das trocas simbólicas fazem parte desse novo estado de coisas, engrenagem que não se reproduz sem o concurso decisivo dos especialistas na promoção de estilos de vida, para falar como alguns teóricos menos apologéticos. Eles são os intermediários ${ }^{4}$, os animadores, os promotores de uma nova ordem que em princípio, de acordo com o papel de consciência crítica delegada junto à sociedade que sempre lhes coube (ao menos desde o Iluminismo) deveriam questionar. Hoje a teoria, na sua acepção americana dominante (bem como os "estudos culturais" que ela alimenta) foi rebaixada à condição elementar de álibi, na forma de uma tagarelice sem fim, de redundância apologética. O papel crucial desempenha-

4. A expressão é de Bourdieu. Cf. a respeito Mike Featherstone, Cultura de Consumo e Pós-Modernismo, São Paulo: Studio Nobel, 1995. do pelo momento reflexivo da instância cultural deixou de ser uma evidência oposicionista.

Em consequência, a ideologia foi passando do discurso para as próprias coisas, transformadas numa rede infinita de significações intercambiáveis, a "animar" um mercado cada vez mais exigente e diferenciado. De supplément d'âme, a cultura parece ter se transformado num ingrediente indispensável da governabilidade (que nada tem a ver com cidadania ou legitimidade democrática), numa nova modalidade de falso gasto público (na acepção keynesiana do termo). O cultural como "animação", sem alma por certo, tornou-se o grande fetiche dos nossos dias. Sabemos faz tempo que nada está fora do alcance da febre do consumo, muito menos a cultura e seu prestígio, mas agora o próprio ato de consumir se apresenta sob a aparência de um gesto cultural legitimador, na forma de bens simbólicos - como se disse à exaustão: de imagens ou de simulacros. É a forma-mercadoria no seu estágio mais avançado, como forma publicitária. O que se consome é um estilo de vida e nada escapa a esta imaterialização que tomou conta do social.

Antes um direito, agora uma obrigação político-administrativa, a cultura tornou-se peça central na máquina reprodutiva do capitalismo, a sua nova mola propulsora. Conscientes disso, alguns governos, embora acossados pela crise e pela avalanche neoliberal, não titubearam, por exemplo, em restringir o orçamento do sistema previdenciário e ao mesmo tempo investir no campo do culturel em expansão (de retorno seguro e rápido), fundindo publicidade e "animação cultural” (o exemplo máximo foi sem dúvida a França de Mitterand). Mas mesmo neste campo, o da cultura pretensamente "desinteressada", os desmontes dos Estados Nacionais acabaram se fazendo 
sentir e as subvenções inviabilizadas vão sendo transferidas (embora na maior parte das vezes via incentivos fiscais) para a iniciativa privada, implicada como parceira (para manter o eufemismo em voga) na manutenção desta nova "democracia" cultural. Sem muito esforço, diga-se de passagem, pois o empresariado, ou os financistas de plantão, já estão agora cada vez mais conscientes do papel reprodutor da cultura. O "consumo da cultura" (que, justamente por ser consumo, não tem mais nada a ver com a função de "esclarecimento" que a cultura algum tempo exerceu, ou por outra, tornou-se enfim, tal esclarecimento, um engodo de massa, como dizia uma antiga teoria crítica) é portanto um dado objetivo do capitalismo hoje, uma inércia aparentemente incontornável - fetichismo é isso. Responsável em última instância pela tão celebrada convergência da cultura dita superior e suas manifestações industrializadas: não há mais distância alguma entre a procura em massa por uma gratificação narcísica no ato de consumir um estilo de vida, e a atual abordagem highbrow da tradição cultural, pois eliminada a antiga mediação da forma que garantia objetividade e recuo crítico, um Ego análogo ao do público pop assimila a "obra" como uma atividade de autotransformação, como quem adota, ou melhor adquire, um novo vocabulário com o qual se redescrever em sua identidade expandida.

É esta emergência do culturel administrado de forma personalizada segundo exigências de um mercado segmentado, alimentando todo tipo de manifestação cultural, dando espaço para as diferenças, que por sua vez, segundo o jargão em vigor, se intercomunicam, intercambiam, hibridizam, num amálgama indiferenciado, sem limites e sem hierarquias pré-estabelecidas, que faz com que se tenha a sensação de viver no melhor dos mundos possíveis, onde todos têm a palavra. Na verdade, a proliferação discursiva que a acompanha apenas reproduz este mesmo fenômeno. Na medida em que, como já foi dito, a realidade tornou-se sua própria ideologia, não há mais necessidade de justificar os altos investimentos das ditas "políticas culturais".

\section{A "comodificação" urbano-cultural}

Voltando à cidade. No plano da vida urbana tudo se passa como se a tarefa coletiva - Estado e iniciativa privada - tivesse por obrigação reproduzir, embelezando, monumentalizando, se for preciso, o caos urbano, afinal fruto de uma organização espontânea dos indivíduos no livre exercício de seus direitos e criatividade. O processo induzido de gentrification vai tomando a forma mais flexível de algo que se aproxima daquilo que os antigos "propagandistas" da identidade estão preferindo chamar de transculturalismo, translocalismo, nomadismo, fronteira (não como limite fixo, mas como o que pode ser transposto, deslocado, diferido, etc. - margem, edge), mestiçagem, etc.

Num de seus ensaios sobre esse processo de expansão da cultura, Mike Featherstone afirma que justamente o excedente monetário (melhor dizendo, uma das resultantes do processo de financeirização da riqueza) vem sendo utilizado, desde a última década, em grande parte, diz ele, "para financiar a arquitetura pós-moderna, ou inflar os mercados de artes, ou ainda as formas como algumas grandes cidades ocidentais estimulam especialistas simbólicos (os novos intelectuais mencionados linhas atrás) a ocuparem áreas urbanas 
em processo de recuperação (por exemplo, o Soho em Nova York), para acelerar sua gentrification e uma elevação geral no prestígio e no capital simbólico da cidade."5

Seria o caso de lembrar muito a propósito o quanto este tipo de requalificação vem sendo aplicado em nossos centros urbanos (à brasileira, é claro: entre outros sirva de exemplo barateado o Pelourinho de Salvador, convertido em cenário para estereótipos baianos). Tais processos de gentrification com vistas a alterar o perfil sociocultural das cidades não podem deixar de suprir a demanda crescente de "bens culturais" pela camada social responsável pelas requalificações buscadas por essas mesmas estratégias de gestão urbana.

Da forma-mercadoria à forma-publicidade — seu estágio final -, assistimos pois a um recrudescimento do fetichismo, porém em chave soft. Um exemplo enfático deste atual estado de coisas são justamente os novos-museus, que por certo não proliferam por um novo e surpreendente surto de amor à arte. Novamente é ao processo de culturalização da vida, concomitante ao de comodificação da cultura, a que temos que recorrer para entender o porque do sem número de Centros Culturais, Casas de Espetáculo e Museus (a França chegou a completar mil museus no final da década de 80 , duzentos e cinquenta dos quais construídos ou ampliados no período). Exemplo enfático disso é o atual Museu de Bilbao. Lance político ou ousadia estética? Ou ainda, quem sabe, uma combinação nada inocente das duas coisas?... Não há dúvida de que assistimos, em plena desaceleração econômica e relativo desmanche do Wel-

5.Op. cit.; p.61. fare State nos países Europeus, a uma verdadeira guerra entre os Estados e talvez muito particularmente entre as cidades, na competição desenfreada para conquistar empresas e mercados (e isto não só lá), por museus, centros culturais e reabilitações urbanas interpostos. - E todo este patrimônio cultural, alardeado com estardalhaço, o que exige muita imaginação de arquitetos e urbanistas, vai criando um verdadeiro star system mundial disputadíssimo por um mercado cada vez mais exigente.

Em consequência, mudou radicalmente o papel exercido pelos museus nas novas fisionomias urbanas: antes domínio tradicionalmente austero e introvertido, atualmente, imagem prestigiosa e ponto de vista privilegiado sobre o mundo à volta, onde reina, diga-se de passagem, uma grande animação. Assim, repassando alguns exemplos obrigatórios: para as novas gerações, Paris é com certeza mais rapidamente associada às tubulações coloridas do Beaubourg ou à Pirâmide do Novo-Louvre - imagem que hoje quase tem a força do logotipo da Coca-Cola, de tanto que é utilizada em reclames publicitários, especialmente no campo da moda - do que à velha Notre-Dame ou à Torre Eiffel. Bilbao nunca foi tão comentada - como tudo se deu? Há poucos anos atrás, o diretor da Fundação Guggenheim convenceu o prefeito da cidade a construir um museu cujo edifício pudesse identificar a capital basca como a Ópera em Sidney - para tanto ninguém melhor que o extravagante Gehry que criou, como ele mesmo diz, algo como uma flor de aço a emergir do rio Nérvio - 100 milhões de dólares, mais de $30.000 \mathrm{~m} 2$, 70 de altura, a esperar que a Fundação administre o acervo e o enriqueça com as suas coleções itinerantes (que já não tinham mais onde serem abrigadas), atraindo turistas e trazendo dinheiro. - Negócios de parte a parte. Enquanto $70 \%$ da po- 
pulação desaprova a iniciativa, Gehry se vangloria de sua performance (tanto faz se se trata do Disney-Hall ou do museu de uma das mais pobres e conturbadas regiões da Espanha - parte de seu parque industrial foi desmontado na década passada). Sabemos que lá mesmo houve precedentes bastante louvados pelos novos teóricos e gestores urbanos de plantão: Barcelona, em pleno embalo pré-Olímpico, conseguiu trazer o mais disputado dos arquitetos contemporâneos para projetar um "moderníssimo" Museu de Arte Moderna no Bairro Antigo - Richard Meyer, autor de vários outros museus e que ousou imaginar uma Acrópole para Los Angeles (quem diria): a Fundação Getty. Aliás a "desumana" cidade da Califórnia vai somando pontos nesta "requalificação" cultural do entorno, da Biblioteca e do Museu da Aeronáutica de Gehry ao Museu de Arte Moderna de Isosaki. Mario Botta conseguiu deixar a sua marca na cidade mais carregada de imagens postais - São Francisco. A sonolenta Otawa, até recentemente identificada pela forma gestáltica mais em evidência sua eclética catedral de gosto duvidoso - hoje pode vê-la reproduzida em uma moderna caixa de vidro espelhada, do outro lado do rio: a National Gallery. E os exemplos não param por aí. Não esqueçamos que Trafalgar Square está hoje enquadrada por um enorme cenário, ou melhor, um grande telão: a National Gallery, estendida até o outro lado da praça - obra justamente do arquiteto pop americano, Robert Venturi. Frankfurt oferece uma rua inteira de museus, às margens do Main, ao turista que seguramente também pouco conhece de Stuttgart além da "máquina" colorida de James Stirling. Sem falar na cidadezinha de Mönchengladbach, na Alemanha, que se transformou num lugar de romaria desde que Hans Hollein construiu no alto de uma colina um dos mais festejados museus pós- -modernos, com todo o repertório arquitetônico de uma mini-cidade - o que valeu ao arquiteto algumas outras encomendas aparatosas, entre os quais uma intervenção no museu de Teherã. Mas o Museu da pequena Mönchengladbach ainda pode enganar como contrafação do clássico idílio alemão. Já o de Bilbao, por exemplo, que abraça com sua torre a auto-estrada que atravessa o rio, incorpora, em sua extravagante cenografia, a mais obscena (no sentido técnico que a palavra ganhou depois dos escritos de Baudrillard) efígie dos tempos modernos: a circulação (a bem dizer abstrata) de veículos a toda velocidade.

Aliás, como por contaminação, as próprias cidades foram se transformando em museus: estetização da vida urbana encenada nestes novos "espaços públicos", para a qual até mesmo as nossas administrações mais conservadoras têm se mostrado "sensíveis" (e nem poderia ser de outra maneira). Estava pensando em Salvador, com seu Centro velho devidamente higienizado, embelezado e policiado (por isso mesmo elevado a ponto máximo turístico-cultural brasileiro), mas poderia ser outra cidade qualquer do Brasil, por exemplo, São Paulo: não poderíamos deixar de nos por à la page, tratamos de substituir o velho Viaduto do Chá por um cartão postal mais ao gosto do dia; pintamos de vermelho vivo os pilares de mais um paralelepípedo de vidro da Av. Paulista, não por acaso o Museu de Arte de São Paulo, dando ao mesmo tempo dignidade ao mundo dos negócios, a nossa city (ao menos por enquanto); simultaneamente planejou-se uma ampliação deste mesmo Museu noutro ponto da cidade, na Galeria Prestes Maia, que, alterando suas funções e frequência, há de contribuir para a empreitada - um pouco tateante - de recuperação do Centro; por seu turno, o Museu da Escultura, construído nos Jardins, um bairro nobre, evi- 
tou a deterioração que poderia advir com a construção no mesmo local de um Schopping Center; sem contar que a nova Berrini-Faria Lima também terá direito a sofisticados equipamentos culturais; e assim por diante.

Volto a por no foco o enunciado de nosso assunto: a pretensa "apropriação simbólica" via encenação das diferenças, patrocinadas pelas políticas patrimoniais e culturais dos governos e outras entidades locais, tanto quanto o propósito de acertar contas com o esteticismo e a "frivolidade" das pós-filosofias contemporâneas, cujo "texto" pretende com involuntária razão "apenas" reproduzir este mesmo processo indefinido de desdiferenciação cultural.

\section{Em busca do lugar perdido}

Esboçado esse quadro geral, recapitulemos brevemente aquele processo de deslocamento do enfoque sobre a cidade do qual partimos: mudança que inicialmente se deu como forma de resistência ou antídoto às patologias urbanas, mas que hoje, na maior parte dos casos, se não me equivoco, sobrevive como mera estetização dessas patologias. Aliás, não passam na verdade de estratégias que alguns preferem chamar de "asseguradoras", adotadas num momento em que a administração cultural tornou-se o instrumento máximo de ação política, ou melhor, o sucedâneo desta, enquanto forma de administração dos conflitos sociais.

Num primeiro instante, no imediato pós-guerra, seja como reação à modernização predatória que se consumava nos Estados Unidos, seja como esforço de recuperação das antigas cidades europeias, igualmente destruídas, só que pela guerra, somados à necessidade de refazer o tecido social através da reativação da memória e dos valores locais visíveis tanto nos monumentos comemorativos quanto na arquitetura vernacular, começaram a surgir novas concepções arquitetônicas e urbanísticas que só aos poucos acabaram se firmando como alternativa (nem sempre definitiva) ao conceito de planificação global, ou aos modelos abstratos de reorganização da cidade, tanto quanto ao international style. Valorizando os monumentos ou tentando aglutinar uma série de objetos desconexos (entre os quais, em geral, edifícios monumentais, sedes do poder local, prédios administrativos, etc.), de forma a constituírem um lugar de pregnância significativa, de comunicação imediata, forte, algo como um coração da cidade a revitalizá-la, o que boa parte dos dissidentes do chamado Movimento Moderno - de Giedion, Rogers, Sert, ao grupo inglês MARS, dos CIAMS de Brigwater (1947) à formação do Team X (1956) - visavam era, de alguma maneira, reativar a ideia mesma de "cidade" para os seus habitantes, recriar algo como uma res civica. Fatos urbanos memoráveis que deveriam propiciar aos moradores de uma mesma cidade a oportunidade de reatar com formas de vida social desativadas, reanimar por esse modo, uma vida pública não mais possível em meio ao caos urbano ou às novas cidades, justamente sem alma.

Na sequência, o reconhecimento da impossibilidade de recompor o tecido e urbano e social a partir de tais estratégias levou arquitetos e urbanistas a buscarem outras soluções, tentando deter a deterioração das cidades, mas já então não mais com a pretensão de recriar um core - o que, no limite, reproduzia as ilusões modernistas de reorganização da vida social via reordenação global da cidade; sem contar que a ênfase nos monumentos acabava por querer restabelecer uma dimensão aurática das coisas 
que há muito a vida moderna inviabilizara (como já mostrava Benjamin, desde os anos 30), numa sacralização do urbano que no fundo não passava de mera sublimação de conflitos insolúveis, ou de encenação de uma vida pública inexistente. Sem abandonar entretanto esta operação de salvação da cidade, surgem assim outras tantas propostas alternativas que, em geral, obedecendo a uma palavra de ordem semelhante à que presidira o surgimento das filosofias da existência - "rumo ao concreto" - pretendiam abandonar o ponto de vista abstrato e totalizador. Tratar-se-ia de uma volta à cidade de tipo muito especial, que concebesse toda a arquitetura da cidade como forma-lugar, valorizando portanto a cidade comum, partindo da casa e do bairro, tanto quanto das formas vernaculares, valorizando o contexto, qualquer que fosse, e não apenas os lugares nobres ou a arquitetura áulica. Num certo sentido mantinha-se o caráter prosaico da arquitetura moderna, sem persistir na ênfase da funcionalidade, estandardização e outros preceitos modernos, especialmente o da tabula rasa - era a própria fé na modernização que se achava abalada e que abria caminho para toda a sorte de retorno: ao passado ou ao artesanal, ao popular e assim por diante. Surgiram os contextualismos das mais variadas colorações, onde se combinavam existencialismo e estruturalismo, linguística, antropologia e historicismos de tinturas marxistas ou revivalistas. Tudo isso compondo uma espécie de aspiração à vida social em modelo reduzido - veleidade compensatória que até certo ponto se alimentava de uma nova ideologia da intimidade, à procura de uma outra sociabilidade burguesa sobre a qual se apoiar.

É preciso rever os termos daquele debate dando o devido desconto ao preço pago às ideias dominantes, sem esquecer, no entanto, o quanto os seus termos não se resumiam a simples confusão conceitual ou terminológica, mas trazia a marca da época, ou seja, era resultado, como toda a discussão teórica da qual participava, de um campo mutável de forças que lhe dava sentido. No fundo tratava-se de um momento de transição para uma nova etapa do capitalismo em que as próprias noções de espaço e tempo, de história ou de sujeito, começavam a entrar em crise sem que algo muito claro surgisse como alternativa, inclusive do ponto de vista dos novos rumos do capitalismo. Em consonância, a cidade passava a ser vista como uma rede de relações diacrônicas e sincrônicas, como lugar: corte estrutural de espaço e tempo, condensação simultânea de vários tempos e valores históricos. Na definição de Rossi, "fato singular determinado pelo espaço e pelo tempo, por sua dimensão topográfica e por sua forma, por ser sede de vicissitudes antigas e modernas, por sua memória". ${ }^{6} \mathrm{O}$ lugar, nesta acepção se cristaliza por assim dizer impregnando, circunscrevendo, um espaço determinado - qualificandoo ao convertêlo num fato único, sobrecarregado de sentido (histórico, psicológico, etc.), de camadas de significação que ultrapassam o seu ser bruto imediato. São, portanto, significados em grande parte coletivos, como lembra Rossi (não se pode esquecer contudo que ele ainda privilegiava, apesar das ressalvas, os monumentos - a que chamava de fatos urbanos primários).

Deste ponto em diante, a discussão passava inevitavelmente à questão tipológica, ou seja, às invariantes arquitetônicos ao longo da história e suas relações com

6. La arquitectura de la ciudad, Barcelona: Gustavo Gili, 1983; p.189. Retomo parcialmente aqui e nas considerações que se seguem sobre as teorias do lugar à época, meu ensaio "A ideologia do lugar público na Arquitetura contemporânea" cit. (republicado neste e-book). 
a morfologia urbana, numa palavra, com a configuração do lugar. Gregotti, por exemplo, outro dos arquitetos italianos empenhados na época numa "ressemantização" da cidade, imaginava a arquitetura, segundo o conceito que utilizava, de "lugar simbólico", como "sedimentação histórica”. Nessa direção, contrapondose à noção de história dos mestres do Movimento Moderno, a interpretava como uma espécie de escavação rumo aos estratos ocultos de um fenômeno de superfície, justamente uma quase suspensão do movimento histórico, reduzido a "uma série de configurações sucessivas", como vinha propondo o estruturalismo. A esta orientação, o arquiteto sobrepunha reminiscências do historicismo (o lugar, "enquanto decisão de destinação"), as quais, tudo bem pesado, não deixam de ter o seu propósito, pois na ausência de uma progressão cumulativa, conta apenas a relatividade do fenômeno localizado como soma de instantes incomensuráveis de uma intriga histórica singular. Daí a ênfase no lugarsuporte. ${ }^{7}$

A aspiração pelo "concreto", a que me referi há pouco, exprimia na verdade os dois lados de uma alternativa que conviviam na época, e que eram por assim dizer complementares, e não só nas teorias sobre a cidade. $\mathrm{O}$ estruturalismo navegava a favor da corrente modernizante - portanto, nada mais estranho ao seu espírito do que ressemantizar o que quer que seja, e a cidade não seria exceção, no entanto servia de base teórica, especialmente na sua versão antropológica, para as teorias do lugar, cujo halo culturalista não deixava de ser uma relíquia précapitalista. Ocorre que esta também tinha sua razão de ser, se é verdade que a expansão da racio- nalização capitalista carrega consigo um foco de irracionalismo a um tempo compensatório e estrutural e que se manifesta principalmente nas suas crises cíclicas. Não por acaso o estruturalismo combinava esses dois elementos, positivismo e transgressão.

Contudo - aqui o paradoxo maior desta tendência de repensar a cidade como lugar ou um conjunto de lugares, enquanto repertório simbólico diretamente associado a vivências da "comunidade" local, ou como sedimentação de valores grupais acumulados no tempo -, os teóricos do lugar tinham em mente uma estratégia de resistência. Na verdade, sua obsessão pela arquitetura da cidade como "forma-lugar" resultava de uma consciência aguda das patologias da cidade moderna e expressava a vontade de corrigi-las mediante a recomposição de um vínculo orgânico que o deserto moderno desfizera. Só aos poucos foi se explicitando o que havia de ideológico naquela virada polêmica (não no sentido convencional do termo, meramente apologético, mas em grande parte naquele utilizado por Marx na Ideologia alemã - título sob o qual visava não os representantes do atrasado status quo alemão, mas justamente o pensamento mais avançado na Alemanha da época, que no entanto encarnava uma falsa alternativa radical, mais ou menos como fará mais tarde Lukács, ao ressaltar o momento afirmativo da apologia indireta, como preferia dizer das vanguardas artísticas). Aliás, originalmente funcionou como um princípio ativo de transformação nada desprezível, mas cujas implicações só vieram a se manifestar na medida mesma de sua concretização.

7. Cf. O território da Arquitetura, São Paulo: ed. Perspectiva, 1978. 


\section{A nova "intimidade"}

Num certo sentido, vistos à distância os anos 1960/70, a razão parece ter estado com o duvidoso Robert Venturi ao propor uma arquitetura da comunicação e não do espaço, como sempre fora definida. ${ }^{8}$ Criticando a obsessão dos colegas pela adoção de soluções urbanísticas tradicionais, como as praças com os seus genius loci, Venturi defendia a generalização do modelo das ruas comerciais cheias de anúncios luminosos, portanto, uma arquitetura impura, simbólica, de comunicação vigorosa e imediata, que recorresse a símbolos e sinalizações de fácil decodificação - ao contrário da arquitetura Moderna, expressiva pela forma -, com o que já assumia, de modo muito explícito, a transformação da Arquitetura em arte(?) de massa: forma-mercadoria no seu estágio apoteótico de Advertising e derivados. Ao mesmo tempo, esta nova versão da vida urbana era vista como a contrapartida de um refluxo do indivíduo para o interior doméstico, diante de sua televisão, único meio de contato com o mundo externo, acrescido evidentemente do automóvel - espécie de cápsula sobre rodas dirigida por um computador, enquanto a paisagem à volta parece se desenrolar como as imagens num monitor de TV. Assim, de um lado, a casa, de outro as strip - das ruas de comércio às grandes vias a serem percorridos à toda velocidade com seus outdoors e placas ou símbolos indicativos, em geral de lugares e produtos a serem consumidos. Entre o microespaço da sala e o hiperespaço das grandes autoestradas a diferença seria apenas de

8. Cf. Robert Venturi e Denise Scott Brown, Aprendiendo com Las Vegas, el simbolismo olvidado de la forma arquitectónica, Barcelona: Gustavo Gili, 1978 . escala, em ambos os casos não se trataria exatamente de lugares de estar, mas de circular.

Circulação geral de imagens, com a leveza abstrata da correspondente circulação mercantil, só que agora por assim dizer desconectada de qualquer ligação com o mundo concreto da produção. Proliferação de signos autorreferentes, justamente o tão decantado mundo do simulacro, na versão de seus ideólogos. Na época, afirmações como a de Venturi soavam como uma consagração, no mínimo cínica, da sociedade de consumo, um pouco à maneira dos artistas pop. Sabemos hoje que era o primeiro capítulo de uma tendência que se tornaria francamente hegemônica, tanto na prática quanto na proliferação discursiva acerca da arquitetura da cidade. $\mathrm{O}$ modelo do arquiteto americano vinha do mundo da publicidade, tomava como modelo Las Vegas, consagrava o styling, retirava a arquitetura e a cidade definitivamente do domínio das fine arts ao mesmo tempo que trazia o universo prosaico da mercadoria para o campo estético. Tudo se equivalia neste universo de imagens posta em circulação.

Em contrapartida, seus adversários reivindicavam espaços de vida pública no mais das vezes em termos de reativação de ideais comunitários - o que, na verdade, em vez de uma reminiscência do mundo tradicional erigida em instância crítica dos traumas da modernização, não passavam de uma atrofia da hora presente: os novos ideais de comunidade exprimem uma fobia ultramoderna, o temor da vida civil ativa, contaminada por sua vez pelo vírus da "intimidade", (como foi amplamente exposto por críticos da cultura como, por exemplo, Richard Sennet ou Christopher Lash). Aparentemente opostas, portanto, estratégias como a de Venturi e a dos defensores da cidade-lugar acabarão por coincidir: o arquiteto ame- 
ricano não deixava de ser um contextualista à sua maneira e as teorias do lugar acabaram se revelando outras tantas modalidades de reforço da fragmentação urbana, e de sublimação da ausência de vida pública numa política de neighbourhood. No caso do arquiteto americano, a lição de "modéstia" e realismo também vem das ruas, entretanto não se aprende a mesma coisa em Las Vegas e Bolonha (o grande exemplo de arquitetura contextual e de política patrimonial dos dissidentes europeus): num caso é o strip, a rua americana de comércio que impõe à arquitetura a lei do pop; no outro, como vimos, as questões tipológicas e morfológicas brotam da consciência polêmica de appartenenza a um "lugar". - A convergência final das duas visões que pareciam partir de pontos de vista antagônicos é a prova mais cabal do que vinha observando a propósito do campo de forças materiais que comandam o atual discurso urbano, que por sua vez faz parte também de seu processo de reprodução.

Ao se querer restituir à cidade a sua dimensão cívica, há pois que se atentar para o fato de que o declínio do homem público 9 e o correspondente alargamento da esfera privada - porém desfigurada como intimidade narcisista - está na origem da maior parte das patologias urbanas. Nos termos do nosso problema: na mesma proporção em que se consolida a sociedade de massa, aumenta o domínio privado, mas entendido agora como o domínio daquilo que Adorno chamava o falso imediato. O que se vê é a crescente indiferenciação entre os espaços: o do âmbito doméstico e o do exterior, igualmente sujeitos à temporalidade da circulação das imagens, ou seja, homogeneizados pelo mundo do marketing.Em pouco tempo o desenlace desta

9. Título de um livro de Richard Sennet de 1974. mutação se fará sentir, começando no plano da fraseologia de moda repertoriada no início deste estudo-recapitulação, pois foi o pós-estruturalismo que se encarregou de estilizar e justificar as práticas auto-denominadas dispersivas, descentradas, etc. - exacerbação da individualidade como perda da subjetividade (por isso mesmo sociedade narcísica), morte do $\mathrm{Eu}$, enfraquecimento da vontade, ao mesmo tempo que refluxo para o âmbito individual, comandado por uma lógica da intimidade e assim por diante. Não espanta que um fenômeno similar ocorra com a cidade e suas transformações.

Neste particular o próprio Habermas, à época (início dos anos 60), já se dava conta do problema (e não vem ao caso agora a avaliação, a nosso ver equivocada, que fará acerca da responsabilidade da Arquitetura Moderna neste capítulo crucial), pois achava que não era mais o caso de alimentar ilusões quanto ao complemento urbano de uma possível esfera pública que pudesse voltar a existir. Ou seja, o mundo de vida, exigido como suporte e alimento da esfera pública a ser recomposta à contracorrente do capitalismo avançado, já não podia contar mais com a forma outrora abarcável da cidade. As aglomerações urbanas haviam deixado de corresponder ao conceito de cidade; nelas predominam as conexões funcionais não configuráveis, sem a visibilidade do lugar público, incomensuráveis portanto com a clareza da autocompreensão prática que caracteriza um mundo de vida. (Resta saber onde Habermas irá buscar apoio social para a sua esfera pública pósburguesa - certamente não naquilo que ele mesmo denuncia como "o fetiche de uma presença comunitária”.) Para ele, a demanda de um "lugar" como configuração plástica de um mundo de vida público faz parte portanto do elenco das ideologias da infracomplexidade - o lugar do espaço 
público já não pode mais alcançar uma presença esteticamente apreensível, como parece ser o programa da maior parte destes arquitetos, hoje englobados na denominação genérica de "contextualistas". 10

E no entanto, todo o pensamento mais avançado foi nesta direção e continha um momento crítico inegável. É esta a ambiguidade de nascença desse processo de culturalização da cidade em que as relações econômicas ou de poder se travestem de diferenças culturais a serem preservadas ou cultivadas, como forma de resistência a um tipo de modernização capitalista que, justamente, descaracteriza a diversidade através da expansão de um mercado governado pelo princípio da reprodutibilidade em série, padronizada, estandardizada e assim por diante. Ao mesmo tempo, a intermediação produtor-consumidor via mídia já evidenciava uma metamorfose que seria no mínimo precipitado identificar, à maneira de Habermas, como uma mudança de paradigma - do Trabalho para a Comunicação - , mas na qual certamente a unidimensionalização da cultura e a utopia da aldeia global já era mais do que mera estratégia cultural (no seu sentido tradicional), a rigor já era o amálgama que do seu lado a esquerda também começava a fazer, embora em nome da cultura no plural, especialmente das ainda nebulosas futuras minorias - sobressalto social que culminará nas barricadas de 68, cuja pretensão, como sabido, era deflagrar uma Revolução Cultural que pusesse a imaginação no poder.

Em boa parte, o fenômeno da animação cultural, que chegou a se transformar numa atividade profissional re-

10. Cf. Habermas, A mudança estrutural da Esfera Pública, Rio de Janeiro, Tempo Brasileiro, 1984. conhecida, nasce nesta conjuntura ambígua, encontrando precisamente no Beaubourg e congêneres sua expressão máxima. Pompidou, no fundo, atendia a uma demanda que se desencadeou a partir de maio de 68 - reivindicações que surgiram naqueles anos e que foram tomando conta da cidade. A mencionada multiplicação de museus e centros culturais configura a dimensão mais tangível dessa resposta por assim dizer arrancada graças à pressão tumultuária dos movimentos antifordistas cristalizados na esteira de 68; ao mesmo tempo em que refletia a imagem prestigiosa dos governantes-mecenas, empenhados na difusão das luzes: cultura para todos - palavra de ordem à qual, anos mais tarde, dourando a pílula, o staff de Mitterand acrescentaria o suplemento social-democrata da cidadania restaurada. Num encontro que obviamente ninguém marcara, os caminhos do establishment e dos mais refratários dissidentes acabavam se cruzando em nome da redenção social pela cultura, pairando esta última numa espécie de limbo de abrangência indefinida, dos bens museificados aos estilos de vida elaborados como direito ao exercício da diferença social.

\section{Quando tudo começou}

Estamos, portanto, às voltas com um duplo movimento: no âmbito mais específico do pensamento e da prática projetuais voltados para a arquitetura da cidade, o enfoque contextualista; que por sua vez vinha ao encontro de um processo mais geral de culturalização da vida social que justamente poria em cena a assim chamada Cultura da Cidade e suas respectivas políticas. Convergência em que o ideário de resistência daqueles dissidentes acabou 
se transformando, sem nenhuma violência, em lugar-comum. Mudava o objeto e com ele o seu enfoque. É justo que perguntemos: exatamente quando? E se soubermos determinar a hora histórica, alguma coisa saberemos do rumo e das razões da mudança. Quando exatamente principiou a Era da Cultura?

Não deve ser por acaso que em quase todas as periodizações e mapeamentos da transição da cultura do alto modernismo para a atual lógica cultural, cuja dominante vem a ser justamente uma nunca vista funcionalidade da cultura, os anos 60 sejam centrais (embora se divirja quanto à data exata em que começaram e acabaram aqueles anos). Foi quando novos "sujeitos", como o colonizado, a raça, a marginalidade, o estudante em estado de secessão, foram assumindo o primeiro plano da luta política. Numa palavra, a partir da autodeterminação anti-imperialista, externa e interna, estava traçada a rota das identidades, coletivas ou não, mas em nova chave, a saber, entre psicológica e cultural. Nada que à primeira vista a teoria social clássica (marxismo inclusive) pudesse contemplar. Lugar vago portanto para novas fabulações teóricas.

Registremos a opinião de Fredric Jameson sobre aquele interregno em que se decidiu a sorte ideológica dos dissidentes do sistema - no nosso caso, o antifordismo do regionalismo em todas as suas cambiantes. ${ }^{11}$ Naquela década (lato sensu - mais precisamente, de 57 a 72), a expansão do capitalismo em escala global teria produzido uma imensa liberação de energias sociais e, simultaneamente, algo como um surplus de consciência: terceiro mundis-

11. Cf. Frederic Jameson, "Periodizando os anos 60", in Heloisa Buarque de Hollanda (org.), Pós-Modernismo e Política, Rio de Janeiro: Rocco, 1991 (pp. 81-126). mo, regionalismos, movimentos das minorias, revoltas estudantis, etc. Daí o sentimento generalizado de que então tudo era possível. Ocorre que aquele "desatar global de energias" foi o exato contemporâneo de um processo em que as últimas zonas remanescentes de pré-capitalismo, espaços internos ou não, foram invadidas, colonizadas e submetidas à forma-mercadoria, do Terceiro Mundo ao inconsciente bombardeado pela Indústria Cultural. Vista retrospectivamente, aquela descolonização momentaneamente objetiva provou ser uma ilusão histórica, daí a ambiguidade de que falávamos: uma tal miragem possuía de fato um conteúdo de verdade, tanto é assim que a partir de meados dos anos 70 (quando finalmente termina a década de 60) e ao longo dos 80, assistiremos a um esforço em escala mundial para proletarizar todas as forças sociais liberadas que conferiram àquela década fantástica sua energia; por outro lado, não é menos verdade que a referida miragem libertária só se explica em termos do movimento e do jogo superestrutural tornado possível pela transição de um estágio sistêmico para outro - hoje falaríamos da passagem traumática do fordismo para o atual capitalismo desorganizado, de sorte que aqueles anos foram, nesse sentido, "uma imensa e inflacionária emissão de crédito superestrutural, um abandono universal do referencial do padrão-ouro, uma impressão extraordinária de significantes cada vez mais desvalorizados; com o fim dos anos 60, com a crise econômica mundial, todas as velhas contas infraestruturais voltam então lentamente a pesar".

A ambivalência de que estamos tratando tem muito a ver com isso tudo, pois não há dúvida que estamos testemunhando agora o baixar da poeira levantada por aquela agitação fantasmagórica. É o que se pode depreender, no 
plano da fabulação teórica, das aventuras estruturalistas do Signo, recontadas por Jameson. Nelas, nosso Autor relê em filigrana os primeiros capítulos inaugurais da Era da Cultura: o modo pelo qual a autonomia autorreferente e livremente flutuante da Cultura engolida pelo Significante vai objetivamente se convertendo em algo como um estereótipo hegemônico da prática simbólica na sociedade, consagrada de vez quando não parecia mais possível nem desejável manter vivo pelo menos um fantasma de referência, como "um lembrete espectral" do lado de fora. O mais importante porém é que esse processo de rarefação ou evaporação do referente cultural redundou num encurtamento tal das distâncias, que a cultura por assim dizer passou a se reproduzir em estado bruto. Aqui o grau zero da Era da Cultura, a cuja apoteose estamos assistindo:

"com a eclipse da cultura como espaço ou esfera autônoma, a própria cultura recai no mundo, e o resultado não é o seu desaparecimento, mas a sua prodigiosa expansão, a ponto de a cultura tornar-se coextensiva à vida social em geral: agora todos os níveis tornam-se 'aculturados'(...) tudo afinal tornou-se cultural (grifo nosso)".

Este o pendant do capital fictício de que se falava há pouco, a moeda bruta, abstrata, sem lastro ou referente, enfim a apoteose do fetichismo. Ou como diz o próprio Jameson, "o derradeiro referente ao que o balão da mente estava atado é cortado". Ao mesmo tempo,

“o esfacelamento do Signo em pleno ar determina a queda numa realidade social agora absolutamente fragmentada e anárquica; os cacos da linguagem (os Significantes puros) recaem de volta no mundo, como tantas outras peças de sucata, em meio a todos os outros aparelhos e construções enferrujados e obsoletos que atravancam a paisagem-mercadoria e se alastram pela 'cidade-colagem', a delirante New York de um capitalismo avançado pós-modernista em plena crise".

Numa palavra, não é evidentemente fortuito que a cidade-colagem entre em cena quando tudo finalmente torna-se "cultural", que agora somos convidados a compreender como o resíduo coisificado de antigas energias oposicionistas liberadas pelo capitalismo ele mesmo, em pessoa. $^{12}$

\section{7. "Desconstruindo" a Cidade}

Não é portanto de modo nenhum por acaso que Jameson recorre com naturalidade a uma expressão de época, mais precisamente forjada pelo contextualista Collin Rowe - Collage City (o primeiro também a utilizar a fórmula "arquitetura contextual"). Se Jameson tem razão, não espanta que um fenômeno similar ocorra com a cidade e suas transformações. Não se trata obviamente de uma aplicação, chapada ou não, da teoria à prática, ao contrário, a primeira simplesmente dá forma vagamente conceitual ao que ocorre no âmbito da sociedade, ou melhor, o esfacelamento desta se traduz pela "desconstrução" do discurso, transformado em texto, onde todas as relações

12. Como lembrado, para uma outra interpretação do argumento de F.Jameson, cf. a Apresentação citada de Heloisa Buarque de Holanda, "Cidade ou Cidades?", Revista do Patrimônio, n²3, 1994. 
são reversíveis e as significações indecifráveis. Ao mesmo tempo, tudo se transforma em "texto", a escritura da cidade é da mesma ordem que a do mundo prosaico ou da arte. Tudo se interpenetra. Intertextualidade generalizada, ou seja as identidades culturais começam a ser interpretadas em termos de intransitividade ou de algo como um nomadismo das interculturalidades.

Essa radicalização não tem data precisa, mas talvez só tenha sido enunciada de forma contundente e bem humorada na Trienal de Milão de 1987, quando Eisenman, contrariando frontalmente a intenção da mostra, tentou "descontruir" uma região central de Roma em nome da libertação dos romanos de valores "sem vigência" que lhes eram autoritariamente impostos pela preservação de pretensos monumentos públicos. Em franca oposição, Purini, um dos organizadores, apresentava para a mesma região um projeto unitário, uma solução que, acreditava, retornasse à origem da cidade e de algum modo reproduzisse o evento mítico do seu nascimento. Apostando ainda, como se vê, num modelo que já se estava exaurindo (afinal a Trienal daquele ano ainda se dava sob o signo da preservação e do contextualismo). Ao contrário, a proposta extremada do arquiteto novaiorquino - na radicalidade que a reduzia a um mero gesto sem consequências práticas - já anunciava uma outra visão da cidade, para além da noção clássica de topos, a driblar as "artimanhas da razão totalizadora" (cf. Derrida sobre o choral work, projetado para o Parque de La Villette em parceria com Eisenman). ${ }^{13}$

Prova de que os ventos mudavam é que justo um ano

13. Cf. Catálogo da XVII Trienal: La cittá immaginate, Milão: 1987, especialmente vol.2; pp.18-26 e 40-41. mais tarde, na exposição A Imagem da Cidade, no mesmo prédio da Trienal, o tom dominante será completamente diferente. Um de seus apresentadores, por exemplo, Georges Teyssot, lançara mão de toda a terminologia em voga, pós-estruturalista, para explicá-la: "A Metrópole posta em representação" não é mais do que uma "mise en scène de irracionalidades proliferantes". Portanto, tornaram-se absoletos mapas, gráficos, eixos, hierarquias, diante da desterritorialização, dessimbolização, errância, delírio esquizóide (citando Ballard, mas seguramente tendo também em mente Lacan, Deleuze, Guattari, etc.). ${ }^{14}$ Clara demonstração da abrangente hegemonia da Ideologia Francesa, presente igualmente no raciocínio urbano e no debate arquitetônico atual. Tudo se transforma em qualidades movediças ou atributos flutuantes, derrogações, desconstruções, derivas. Shinohara dirá: o "caos" virou um conceito chave, os objetos aleatórios da paisagem de Tóquio prenunciavam a cidade eletrônica em que ela vai se transformando..$^{15} \mathrm{O}$ mesmo modelo ou antimodelo se reproduz em escala internacional.

Dois exemplos deste atual estado de coisas, não por acaso, duas experiências francesas de meados da década passada: Hérouville-Saint-Clair, uma ZUP com tudo que faz dela uma excrescência, fruto de imposições do Estado - autoestradas, zoneamentos, HLMs, nos moldes do urbanismo moderno anos 60 -, desejando se transformar numa verdadeira cidade e deixar de ser um mero aglomerado; e Mellun-Sénart, uma cidade esparramada, uma das "cidades-novas" que se criaram à volta de Paris resultantes da

14. "La métropole mise en représentation", in Urbanisme: la ville entre image et projet, Paris: Cahiers du CCI n.5, 1988 (pp. 10-18).

15. "Villes, Chaos, Activités", in ibid. (pp. 43-51). 
junção de pequenos vilarejos com morfologias, composição social e tradições díspares, necessitando portanto de um acontecimento arquitetônico que os unificasse. ${ }^{16}$

No primeiro caso, o prefeito recorreu a Fuksas que, ao invés de propor um monumento, uma forma unívoca, homogênea, ou um cenário que lembrasse os centros tradicionais das pequenas cidades (foi o que ocorreu com muitas destas "cidades novas"), teve a ideia de uma torre multifuncional e multiformal, convidando para tanto quatro arquitetos a projetarem algo como um "cadavre exquis". Ainda uma referência visual forte, mas que mimetizasse a desordem urbana à volta - tematização ou consagração da desordem? Pierre Goulet a chama de "Torre catastrófica" e lança um desafio: "e o que há de melhor do que condensar, do que monumentalizar a anarquia à volta?" Trata-se sem dúvida de uma estratégia e não apenas de uma estética - é ele quem o diz e não por acaso compara à cadeia BEST do grupo SITE.

No caso de Melun-Sénart, ao contrário por exemplo de Sarfati que tomou a centralidade a sério (embora em outras circunstâncias fizesse o elogio da poética da desordem e de algo como a sublimação do caos) ${ }^{17}$, o projeto apresentado em concurso por OMA-Koolhaas procurava justamente trabalhar com a desordem no plano do desenho, de forma menos alegórica e mais efetiva do que Fuksas: um conjunto de faixas cruzadas que se inscreveriam sobre o terreno como um ideograma chinês, delimitando ora vazios, ora áreas com funções e arquiteturas diver-

16. A respeito dos exemplos citados mais os comentários de Patrice Goulet e Arnaud Sompeirac, cf. Urbanisme, la ville entre image et projet cit.; pp.60-72.

17. Cf. o Projeto para a RN7, em Architecture d'Aujourd'hui nº262, abr.1989 (pp. 86-89). sas, mas com pontos de contato que agiriam como campos magnéticos. Na expressão do arquiteto holandês, tratar-se-ia de buscar uma "instabilidade programática" que reproduzisse o ritmo da vida moderna. ${ }^{18} \mathrm{Já}$ Himmelblau propôs algo como linhas de força também, mas em conflito, obedecendo a lógicas diferentes que viriam a animar o futuro desenvolvimento da cidade - travar-se-ia aí uma verdadeira batalha, na forma de um "urbanismo épico", na visão de Sompeirac. ${ }^{19}$ De qualquer modo são todos exemplos que abrem mão de qualquer esforço de retificação da desordem, seguramente nem sempre como consagração, ao menos no plano mais remoto das intenções - quem sabe uma forma de explicitação das mazelas urbanas via redundância enfática. (É ao menos o que parece acreditar Jameson a propósito dos megaedifícios de Koolhaas e de alguns projetos de Frank Gehry, do que aliás tende a discordar seu conterrâneo Mike Davis, que vê nisto, especialmente nas obras para Los Angeles de Gehry, apenas "inteligentes sublimações"20).

Assim, cada vez mais teóricos, arquitetos ou gestores urbanos parecem abrir mão, não só de qualquer planifi-

18. Esta pelo menos é a tônica dos projetos do grupo OMA-Koolhaas no período. Veja-se, por exemplo, o projeto para La Villette ou para a Biblioteca de Paris. É bem verdade que posteriormente ele declarará ter se desinterssado pelo caos, já sedimentado como "besteira estilística", daí a diferença de seu projeto para Lille em relação aos anteriores. (Cf. entrevista publicada na revista Projeto $\left.\mathrm{n}^{\circ} 133,1990, \mathrm{pp} .34-46.\right)$

\section{Texto cit.}

20. Jameson, "O utopismo depois do fim da utopia", in Pós-Modenismo, a lógica cultural do capitalismo tardio, trad. de Maria Elisa Cevasco, São Paulo: Ed. Ática, 1996 (pp.171-195); e "Os limites do pós-modernismo", in Espaço e Imagem, Teorias do pós-moderno, Org. e trad. de Ana Lúcia Almeida Gazzola, Rio de Janeiro: Editora UFRJ, 1994 (pp. 174-234); e Mike Davis, Cidade de Quartzo, trad. Renato Aguiar, São Paulo: Scritta, 1993 - especialmente cap. "Fortaleza LA". 
cação global da cidade, mas de todo tipo de organização, mesmo parcial, que a torne um conjunto de espaços minimamente ordenados e que possam vir a se constituir em formas definidas e estáveis, de modo a fornecer uma imagem coerente a ser visualizada ou representada por seus habitantes como um tecido coeso, com alguma pregnância visual ou semântica, configurando (na terminologia que dominou o pensamento urbano até recentemente) um "lugar". Restam quando muito formas e símbolos vazios, imagens que não remetem a nada, salvo à publicidade delas mesmas. Aliás, o novo jargão se compõe de termos que, ao contrário do anterior, procuram designar a não urbanidade da cidade, sua atopia - a cidade como não-território, lugar virtual, não-lugar, etc. Virilio chega a falar numa desurbanização pós-industrial, ou em concentrações pós-urbanas, onde a cidade desapareceria na "heterogeneidade do regime de temporalidade das tecnologias avançadas". ${ }^{21}$ A topologia eletrônica daria origem à instantaneidade de um presente em permanência. Não seria apenas o espaço/lugar a desaparecer, mas também o calendário de uma memória coletiva. Os muros da cidade teriam sido derrubados ao som da mídia.

\section{Conclusão}

Da busca quase obsessiva pela restauração de uma urbanidade perdida - a cidade como lugar público - passa-se pois à apologia do caos, da cidade labiríntica, da errância, da (des)ordem, etc. O que se viu foi que as intervenções que desde as primeiras secessões do Movimento Moderno

21. Cf. O espaço crítico, São Paulo: Editora 34, 1993. pretendiam regenerar o tecido urbano através de uma revitalização da cidade, numa verdadeira empreitada de reconquista de uma identidade local que reforçasse os laços sociais - requalificações que respeitassem o contexto, sua morfologia ou tipologia arquitetônica, preservando os valores locais (este ao menos o discurso que acompanhava tais iniciativas) - foram se fracionando em intervenções cada vez mais pontuais e restritas. Assim, embora adotado pelos melhores e mais empenhados arquitetos do pós-guerra (especialmente na Europa - Bolonha tornou-se um paradigma), um tal esforço concentrado de salvação da cidade acabou se revelando uma forma, adotada inclusive pelo establishment, de administrar as contradições, camuflando os antagonismos e a miséria crescente. No mais das vezes tais iniciativas se resumiam a criar cenários destinados literalmente a fascinar, verdadeiras imagens publicitárias das administrações locais, sem nenhuma continuidade com práticas sociais que lhes dessem conteúdo. Passo seguinte: recorrendo às mais avançadas técnicas de comunicação de massa forjaram-se identidades para todos os gostos - proliferação de imagens que por isso mesmo não informavam mais nada.

A verdade é que a "modéstia" de que falávamos acabou se revelando muito pouco modesta e além do mais a reboque de uma causa surpreendente e, aparentemente ao menos, antagônica - a de um urbanismo anárquico, de reforço da desordem urbana. A meu ver, a ideologia do Plano acabava sendo substituída por outra não menos integrada - a ideologia da diversidade, em que os conflitos são maquiados por uma espécie de estetização do heterogêneo. Uma tal política teria, portanto, redundado no seu contrário, acompanhando o processo de modificação do capitalismo que ia alterando a própria fisionomia da 
cidade, já agora convenientemente estilhaçada. A lógica que aí se esconde não é outra senão a da racionalidade sabidamente perversa do mundo da reprodução material da sociedade, para a qual o reforço das particularidades é a contrapartida da globalização.

Esta mundialização do capital, para chamar a coisa pelo seu verdadeiro nome, que é econômica, tecnológica, midiática, gera descompassos, segregações, guetos multiculturais e multiraciais, ao mesmo tempo que desterritorializações anárquicas, crescimentos anômalos e transgressivos - verdadeiros focos explosivos que devem esgotar suas energias numa entropia intransitiva, numa guerra interna generalizada, de facções e gangues, enquanto consomem e exportam formas culturais e religiosas cada vez mais sincréticas, criando uma vaga sensação generalizada de reconciliação democrática (em geral video-eletrônica.) Reposição das diferenças que não é senão sublimação cultural, forjando, na ausência de referências sociais objetivas, identidades meramente simbólicas. Além do mais, as novas tendências estruturais de crise da regulação social e de desmonte dos Estados nacionais, transforma os alegados valores locais em mercadorias a serem igualmente consumidas e recicladas na mesma velocidade em que se move o capital. Em linhas gerais, esse o nó da renovação urbana em andamento tanto nos países afluentes, quanto, com mais razão ainda, na periferia.

Mais do que um bem supremo em si mesmo que mimetizasse à distância a finada esfera superior e separada de aprimoramento individual máximo, coroando o antigo regime burguês, a cultura passa hoje por elemento essencial ao próprio processo de reprodução material da sociedade. É o que explica a escala de massa da animação cultural das nossas cidades, cada vez mais conscientes de sua própria dimensão imagética e cultural. Digamos que este mundo de faz-de-conta vai sendo estimulado pelo que continua, apesar de tudo, a ser chamado de "políticas culturais", e isto, na mesma proporção em que a segregação social assume características cada vez mais sinistras. Nunca a cultura apresentou um caráter tão "afirmativo", tal o descaramento de sua funcionalidade. Por isso mesmo já não é mais necessário servi-la acompanhada de qualquer discurso ideológico - basta pô-la em movimento, sem frase, em que pese a interminável tagarelice de seus animadores. 


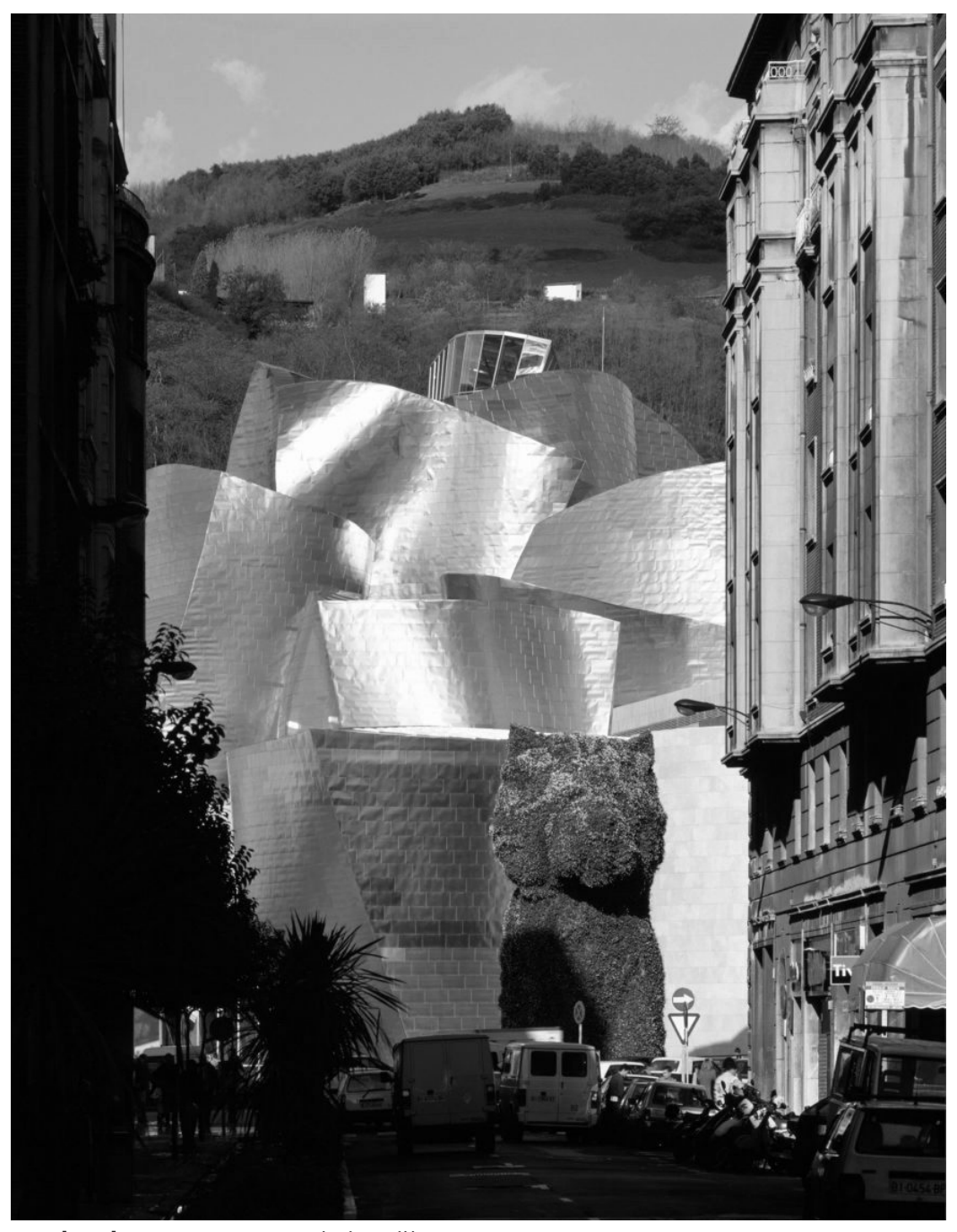

Frank Gehry, Museu Guggenheim Bilbao, 1993-97

\section{Uma estratégia fatal, a cultura nas novas gestões urbanas ${ }^{1}$}

Não é de hoje que o estudo da arquitetura e da cidade depois dos Modernos se defronta com desencontros que os clássicos caracterizariam como processos de ironia objetiva, desses que convertem as melhores intenções no seu avesso, realizando, não por desvio mas por finalidade interna, o contrário do que prometiam. Ironia redobrada, no caso da arquitetura, sobretudo depois que os modernos romperam com o sistema das belas-artes, tornando projeto e existência indiscerníveis. Esgotamento do Movimento Moderno, que voltou a ser comprovado na falsa ruptura dos pós-modernos, cuja oposição de fachada mal escondia

1. Esse texto foi escrito a partir da comunicação apresentada na sequência intitulada "Cultura da cidade", no Simpósio Internacional sobre Espaços urbanos e exclusão socioespacial. Práticas de inclusão, promovido pela FAU-USP, de 4 a 6 de novembro de 1998 (um resumo sucinto dos principais pontos do argumento está no artigo Vendo Cidades, em Veredas $\mathrm{n}^{\circ} 36$, Rio de Janeiro, dez.1998; pp.21-23) - à qual acrescentei outros desdobramentos do tema, apresentados em conferências e debates realizados nos dois anos subsequentes. Publicado em Otília Arantes, Carlos Vainer, Ermínia Maricato, A cidade do pensamento único, Petrópolis: Ed. Vozes, 2000, e reproduzido-revisado e levemente modificado - nesta edição em e-book. Optei por não atualizar os exemplos ou os desdobramentos posteriores dos processos aqui analisados, sob pena de, ao fazê-lo, ter que atualizar também a bibliografia e recorrer a outros esquemas interpretativos, visto que, evidentemente, as cidades foram sofrendo metamorfoses que obrigaram os novos gestores urbanos a adotarem diferentes estratégias (ou novas variantes do modelo aqui exposto) - não obrigatoriamente menos fatais... (Remeto o leitor aos meus textos posteriores, em especial: Berlim, Barcelona, duas imagens estratégicas, São Paulo: Annablume, 2012/13; e Chai-na, São Paulo: EDUSP, 2011). Agradeço a Paulo Eduardo Arantes as inúmeras sugestões na elaboração deste texto. 
o seu vínculo com o formalismo do ciclo anterior. Portanto, continuidade onde se esperava reviravolta - autora incluída: por um momento pensei reconhecer no contextualismo europeu o embrião de um desenvolvimento alternativo, logo desmentido, não só pelo exame mais detido do discurso do "lugar", mas igualmente pelo estudo de um caso exemplar: a contaminação entre os dois lados da arquitetura francesa, então reanimada pela invenção de um centro cultural como o Beaubourg, mais exatamente, o espetáculo urbano posterior, oferecido pelo reforço mútuo dos canteiros midiáticos do Grandes Projetos da era Mitterrand e a alegada resistência das intervenções "modestas", alinhadas com a integridade morfológica do entorno. Convívio promíscuo que põe lado a lado a cultura do dissenso e os donos do dinheiro e do poder - algo que seguramente tem a ver com o rebaixamento de horizonte após a Queda: e não me refiro apenas à derrocada soviética, mas também às demais construções "progressistas", como o Welfare State central e as industrializações periféricas. Como estarei confrontando a seguir o mais recente episódio dessas reviravoltas niveladoras, seria o caso de perguntar se afinal não seria este amálgama ideológico uma fatalidade da hegemonia global que parece anunciar um novo Império. Espero que este capítulo contribua para desfazer tal impressão de caminho único.

\section{Uma nova geração urbanística?}

Nessas circunstâncias, gostaria de reexaminar a situação de fim de linha em que se encontra o pensamento da cidade desde o colapso da modernização urbana, ${ }^{2}$ com o intuito de avançar um pouco mais no diagnóstico - certo ou errado, um diagnóstico do nosso tempo, dado o papel decisivo que os desmanches nacionais parecem estar conferindo às novas localizações urbanas. Uma nova geração? Tenho dúvidas. O que está sendo chamado de "terceira geração" urbanística, a meu ver, não representa - mais uma vez... - nenhuma ruptura maior de continuidade com a anterior. Se há novidade, ela se resume ao "gerenciamento", como se diz no novo jargão, agora assumidamente empresarial, de um lado e do outro do oceano - o que a levou, não por acaso, a ressuscitar o vocabulário descartado do "planejamento", posto em descrédito pela voga contextualista anterior.

Assim, para começar: em comum com a geração que a antecedeu, e que tomou o caminho de volta à cidade, a mesma e paradoxal "animação urbana”, ao que parece, cada vez mais intensa, na medida mesma em que as escolhas alternativas se estreitam (inclusive no Brasil, a se julgar pela última Bienal de Arquitetura). Animação que se expressa na convergência entre governantes, burocratas e urbanistas em torno de uma espécie de teorema-padrão: que as cidades só se tornarão protagonistas privilegiadas, como a Idade da Informação lhes promete, se, e somente se, forem devidamente dotadas de um Plano Estratégico capaz de gerar respostas competitivas aos desafios da globalização (sempre na língua geral dos prospectos), e isto a cada oportunidade (ainda na língua dos negócios) de renovação urbana que porventura se apresente na forma de uma possível vantagem comparativa a ser criada.

2. Ver meu livro: Urbanismo em fim de linha, São Paulo: EDUSP, 1997. 
Dito isto, devo esclarecer que enfrentarei o problema (como aliás venho fazendo) de um ângulo bem específico, e não por razões estritamente profissionais, mas porque este aspecto particular tornou-se central. E é precisamente o porquê desta centralidade que pretendo analisar, ou seja: por que o novo planejamento urbano, dito estratégico (mesmo quando fica o dito pelo não dito), que se pretende novo, ao menos em relação às intervenções pontuais do período anterior, e contrastante, por desenterrar e pelo menos reabilitar (noutra chave é claro) uma expressão derivada da falida "ideologia do plano", não só relançou como manteve o foco na alegada dimensão cultural do impulso dito (também) historicista do paradigma prevalecente durante a fase de reação ao naufrágio histórico do Movimento Moderno?

Obviamente a pergunta perderia sua razão de ser se não houvesse uma incompatibilidade de princípio entre o caráter sistêmico-funcional da ideia de estratégia e a fragmentação, a ser respeitada ou induzida, inerente à valorização da diferença com a qual, por definição, a dimensão cultural se confunde enquanto esfera refratária à homogeneidade imposta ou requerida pela velha ideologia da ordem. Noutras palavras, e invertendo a sequência estratégia/cultura: políticas (urbanas) de matriz identitária podem ser estrategicamente planejadas? Algo como calcular o espontâneo, ou derivar a integridade ou autenticidade de uma escolha racional - para falar como os economistas do individualismo metodológico - que implica ponderações do tipo custo/benefício, qualidade/ preço etc. Com isso já estamos avançando no enunciado da questão, ou seja, a confluência que está nos embaraçando desde o início. Como a própria terminologia corrente já indica, estamos diante de políticas de image-making, na mais trivial acepção marqueteira da expressão, pois quem diz image-making está pensando, queira ou não, em políticas business-oriented, para não falar ainda em market-friendly, mesmo quando fala de boa fé em conferir visibilidade a indivíduos ou coletividades que aspiram à tal promoção.

Não diria que continuamos na mesma, mas se trata, creio eu, de uma etapa a mais na abordagem culturalista da cidade, ao mesmo tempo que corresponde a uma nova inflexão no assim chamado, a torto e a direito, cultural turn (para designar as mudanças ocorridas a partir dos anos 60, em grande parte resultante dos movimentos libertários daquela década). Por assim dizer, segundo turno, portanto, no qual essa tão falada mudança de paradigma (em todos os níveis, da regulação econômica à filosofia) coincidiria enfim com a sua verdade, no fundo, a verdade do nosso tempo, uma idade enfim inteiramente dominada pela compulsão da generalized bargaining (própria da integração social pelo valor de troca) em que tudo se negocia (não há texto pós-moderno em que não se esteja "negociando" alguma coisa), de imagens a outros itens menos simbólicos, numa espécie de arrivismo interacionista quase metafísico. O que, aliás, não deveria surpreender, pois o seu cenário de origem vem a ser o do movimento de volta à cidade, no mais das vezes dando origem aos conhecidos processos de gentrification (ou "revitalização urbana", conforme preferem falar seus promotores), em grande parte desencadeados pelo reencontro glamouroso entre Cultura (urbana ou não) e Capital. ${ }^{3}$

3. Como sugeri em outras ocasiões e voltarei a insistir. Cf. em especial "Cultura da cidade, animação sem frase", em Revista do Patrimônio n ${ }^{\circ} 24$, 1996; pp. 229-240. Republicado, numa versão ampliada, em Urbanismo em fim de linha cit. e reproduzido aqui neste volume virtual. 
É desnecessário dizer que a recapitulação do roteiro cumprido pelos dissidentes da racionalização moderna, com suas periodizações e guinadas, não tem outra finalidade senão a de entender a quase naturalidade da assimilação que estamos testemunhando. ${ }^{4}$ Para tanto, é necessário não perder de vista a presença contínua da isca cultural. Uma autorreferência talvez ajude a esclarecer o meu ponto - na verdade, trata-se de um registro aparentemente óbvio, feito por mim há alguns anos atrás, mais ou menos nos seguintes termos: quando, nos dias de hoje, se fala de cidade (pensando estar "fazendo cidade"...), fala-se cada vez menos em racionalidade, funcionalidade, zoneamento, plano diretor, etc., e cada vez mais em requalificação, mas em termos tais que a ênfase deixa de estar predominantemente na ordem técnica do Plano como queriam os Modernos - para cair no vasto domínio passe-partout do assim chamado "cultural" e sua imensa gama de produtos derivados. ${ }^{5}$ Menos óbvio lembrar que aquela caudalosa fraseologia estetizante, a pretexto de respeitar os valores locais e sua morfologia, tenha servido de maquiagem para a entropia galopante das metrópoles. Àquela época, 1995, eu estava mais preocupada em chamar a atenção para esse fato, espanando a poeira otimista dos contextualismos ou regionalismos críticos $^{6}$, sem dar muita atenção (apesar de ter tido oportunidade de ver de perto a experiência de Barcelona) às pretensas correções de rota que, por sinal, já estava incorporando tais valores

4. Para a sofística da assimilação, ver um esboço do argumento em artigo de mesmo título de Paulo Eduardo Arantes, praga nº8, 1999; pp. 75-100.

5. Cf. “Cultura da cidade..." cit.; pp.146-147.

6. Aliás, já um ano antes, num Congresso do do.co.mo.mo, na Bahía, dando conta de mais esta reviravolta, recorri à expressão "regionalismo pós-crítico". em pacotes "estratégicos", vendidos mundo afora como uma nova fórmula de sucesso e emparelhamento futuro com as metrópoles centrais que estavam dando certo... Aliás, por isso mesmo, é sem descontinuidade que posso passar, agora, à reconstituição do encadeamento objetivo que acabou engolindo, numa estratégia fatal, a nova (?) esquerda urbanística.

Vou portanto me concentrar de preferência nas estratégias culturais da cidade-empreendimento de última geração: quer dizer, no mapeamento e periodização do quadro geral em que se dá o presente retorno ao planejamento, pouco importa se chamado ou não de estratégico. Já disse, e repito, que não veio para corrigir, como alega, o antiurbanismo (para uns anárquico, para outros preservacionista, ou ainda, reformista) da geração anterior. Pelo contrário, como estou procurando demonstrar, veio agravar ainda mais o inchaço cultural imperante desde que governantes e investidores passaram a desbravar uma nova fronteira de acumulação de poder e dinheiro - o negócio das imagens. O "tudo é cultura" da era que parece ter se inaugurado nos idos de 60 teria pois se transformado de vez naquilo que venho chamando de culturalismo de mercado. De tal forma que a cultura - que nos primórdios da Era Industrial se cristalizara como esfera autônoma dos valores antimercado -, ao tornar-se imagem, quer dizer, representação e sua respectiva interpretação (como sabe qualquer gerente de marketing numa sociedade do espetáculo), acabou moldando, de um lado, indivíduos (ou coletividades "imaginadas") que se autoidentificam pelo consumo ostensivo de estilos e lealdade a todo tipo de marca; de outro, o sistema altamente concentrado dos provedores desses produtos tão intangíveis quanto fabulosamente lucrativos. Trocado em miúdos, esse o verda- 
deiro "poder da identidade". ${ }^{7}$ Daí a âncora identitária da nova urbanística. E como o planejamento estratégico é antes de tudo um empreendimento de comunicação e promoção, compreende-se que tal âncora identitária recaia de preferência na grande quermesse da chamada animação cultural. Inútil frisar nesta altura do debate - quase um lugar comum - que o que está assim em promoção é um produto inédito, a saber a própria cidade, que não se vende, como disse, se não se fizer acompanhar por uma adequada política de image-making.

Indubitavelmente, um fenômeno espantoso, principalmente se pensarmos nos bons tempos do contextualismo que se imaginava sinceramente dissidente, ou até mesmo no racionalismo explícito dos Modernos: quando um moderno propunha uma cidade segundo o modelo de linha de montagem fordista, tinha em mente antes de tudo a presumida racionalidade construtiva de tal processo e ficaria sinceramente chocado, como de fato ficaram (por acreditarem que se tratava de um desvio de rota), se lhes fosse exposta a dura verdade de sua funcionalidade sistêmica por assim dizer de nascença. Duas gerações urbanísticas depois, o que poderia ter sido motivo de escândalo - a revelação da mercadorização integral de um valor de uso civilizatório como a cidade - tornou-se razão legitimadora ostensivamente invocada: aqui a novidade realmente espantosa, e tanto mais, que eficiente, não só por deixar a crítica espontânea da cidade-empresa com a sensação de estar arrombando uma porta aberta, mas sobretudo por contar com a "compreensão" das po-

7. Não por acaso, título de um dos volumes da recente trilogia de Castells, The Information Age, Oxford/Malden: Blackwell Publishers, 1997-98, 3 vols. (trad. em port. pela Paz e Terra). pulações deprimidas por duas décadas de estagnação econômica e catástrofe urbana: fica assim bem mais simples persuadi-las a se tornarem "competitivas", na pessoa de suas camadas "dinâmicas", bem entendido. Esse o núcleo originário da "sensação coletiva de crise", sublimada pela nova ênfase na autoimagem dos habitantes, tal como lhes é devolvida pela superfície refletora dos Grandes Projetos, neste final de século.

Antes de prosseguir, um lembrete quanto à procedência da periodização geracional de que estou me valendo. Até onde posso saber, a designação terceira geração foi posta em circulação pelo urbanista italiano Campos Venuti, num livro de 1987. ${ }^{8}$ Só para situá-lo, responsável pelos novos planos de Bolonha e Florença. Para variar, estamos diante de um outro caso de ironia objetiva em nosso caminho rumo à cidade-mercadoria total, mais um desvio para se chegar a um ponto que se queria evitar, sobretudo porque pelo menos na Europa continental o modelo "estratégico" não estava plenamente configurado. Por terceira geração Venuti compreendia as iniciativas que na Itália se contrapunham ao urbanismo dos anos 70, que, ainda em nome do Estado Social, estava resvalando, em seu ímpeto expansionista e meramente quantitativo, na simples especulação imobiliária de sempre. O novo planejamento - hierarquizador e intensivo -, sendo de oposição, se apresentava como transformador ou "reformista". Voltava-se assim, segundo o autor — ao menos na Itália (ele

8. Cf. La terza generazione dell'urbanistica, Milão; Franco Angeli, 1987/1994 
traça um paralelo com o plano madrilenho dos anos 80 , mas sem deixar de registrar as diferenças) -, a uma visão global da cidade à procura de uma melhor resposta à nova fase de capitalismo flexível e predominância do terciário. Quanto à especificidade propositiva nesse capítulo das intenções, o mesmo ar de família - que aliás ele não nega, tendo muita dificuldade em estabelecer com precisão onde começa ou acaba uma e outra geração. ${ }^{9}$

O programa proposto talvez pudesse ser resumido assim: atenção voltada para as áreas intersticiais, vazias ou degradadas, no sentido de promover o adensamento urbano, porém requalificando-as, seja do ponto de vista do uso, seja dos atributos ambientais; definição de prioridades, áreas nevrálgicas ou propícias à intervenções acupunturais, corrigindo o ponto de vista centralista do período anterior (justamente a contrapartida do expansionismo periférico, desprovido de serviços e sem qualidade), e assim por diante. Venuti acreditava, sinceramente, que tais providências contrariavam os interesses rentistas, desfazendo os desequilíbrios territoriais e sociais... Voto piedoso - com o devido desconto da perspectiva colada aos fatos. Entre outros propósitos: corrigir os descaminhos da geração pós-moderna (por exemplo, Aldo Rossi ou Portoghesi), resultado da revanche da arquitetura contra o desenho urbano dos modernos; refrear a valorização aleatória do solo, agora que disporia de um instrumento "racional" para o controle do crescimento da cidade. Mas por

9. O que me faz lembrar uma conversa com Juan Bousquets, em 1991, na qual me disse que entre as intervenções pontuais da era Bohigas na Prefeitura de Barcelona e a gestão dele, já então comprometida com o Planejamento Estratégico, não havia oposição, apenas generalização de uma experiência que, segundo acreditava, dera certo. Venuti, de qualquer modo, estava mais convencido de que as mudanças, mesmo se ainda não suficientemente visíveis, representavam uma alteração fundamental de ponto de vista sobre a cidade. iniciativa de quem e como? Na quarta edição do livro, de 1990, Venuti é obrigado a constatar que a urbanística reformista fora suplantada pela sua linha auxiliar e presumidamente compatível, a urbanística contrattata; numa palavra:

“o regime imobiliário procura - e esta é a grande novidade - concentrar-se nas transformações mais vistosas, as que disporão de maiores investimentos públicos e privados e que serão maximamente valorizados, em poucas áreas que estão sob o controle direto das grandes corporações financeiras, sem qualquer tipo de limitação." 10

Diante disto, propõe para os anos 90, numa última aposta (à maneira da velha guarda), uma reviravolta: uma "síntese cultural e política entre urbanística e ecologia reformista" - missão atribuída justamente à terceira geração. Ora, talvez tivesse faltado a Venuti aquela visão clara dos circuitos de valorização e seus respectivos suportes espaciais que, não por acaso, possuem os investidores no caso, as firmas que acreditava agirem sem peias no período da geração anterior, pois desobrigadas com qualquer tipo de planificação, e que logo encontrarão sua nova fórmula. Um dado que não pode ser esquecido, como parece ter acontecido com o urbanista italiano - ao menos quando formula as metas, procedimentos e atores desse novo planejamento: os efeitos da chamada globalização sobre as políticas de ocupação do território urbano. Algo que os urbanistas estratégicos, ao contrário, não só não ignoram, mas hão de transformar em um dado essencial nos cálculos sobre como tornar uma cidade competitiva.

10. Ibid.; pp. I a VIII. 
Embora por vezes diretamente inspirado no livro citado, um tal planejamento busca, acima de tudo, transformar a cidade-alvo em um nó da rede internacional de cidades, portanto, torná-la atraente para o capital estrangeiro, inclusive no setor imobiliário - porque não? (quanto menos restrições, e quem sabe mesmo mais incentivos, maiores as chances - Venuti escandalizava-se com o óbvio!).

Fechando o parêntesis, vale a ressalva quanto à distância que separa o modelo na berlinda, despistado por referências e citações fora de contexto, do programa exposto pelo urbanista italiano. Creio que o modelo em questão está muito mais próximo da gestão urbana empresarial de matriz americana que acabou se generalizando - depois de atravessar o Atlântico, bem entendido. Seguramente, mais um dos efeitos da hegemonia dos Estados Unidos no mundo dito globalizado.

\section{As máquinas americanas de crescimento}

A naturalidade com que alguns teóricos ou urbanistas encaram o arrastão empresarial, provocado pelo triunfo incontestável do mercado, faz com que o fenômeno transpareça, sem disfarces, nos próprios textos desses autores. É o caso de Peter Hall, cuja percepção desabusada nos interessa em mais de um ponto. Fazendo economia do intermezzo contextualista-culturalizante, Peter Hall dá a entender que a cidade-empreendimento teria nascido das cinzas do consenso keynesiano por uma espécie de reviravolta desconcertante, a rigor, sem mediações e sem maiores considerandos:

"houve um momento na década de 70, em que [o planejamento urbano] começou a plantar bananeira e a virar do avesso (...) O planejamento convencional, a utilização de planos e regulamentos para guiar o uso do solo pareciam cada vez mais desacreditados. Em vez disso o planejamento deixou de controlar o crescimento urbano e passou a encorajá-lo por todos os meios possíveis e imagináveis. Cidades, a nova mensagem soou alto e bom som, eram máquinas de produzir riquezas; o primeiro e principal objetivo do planejamento devia ser o de azeitar a máquina. O planejador foi-se confundindo cada vez mais com o seu tradicional adversário, o empreendedor; o guarda-caça transformava-se em caçador furtivo" (grifos meus). ${ }^{11}$

Sendo o Autor insuspeito de simpatias à esquerda, não se poderia dizer melhor.

Não cabe aqui recapitular em detalhe os fatos que marcaram, nos 70, a grande reversão dos 30 anos de expansão do pós-guerra, sem os quais a falência da economia urbana e o colapso subsequente das cidades continuariam incompreensíveis. Qualquer que seja no entanto o esquema explicativo do longo descenso da economia mundial, o fato é que, com o fim da Era do Crescimento, o planejamento urbano, destinado por definição a discipliná-lo, simplesmente perdeu seu caráter de evidência e cifra da racionalidade moderna, tornando-se o alvo predileto da ofensiva liberal-conservadora, politicamente vitoriosa a partir de 79/80. Como recorda Peter Hall, os think tanks neoconservadores anglo-americanos passaram a década crítica de 70 responsabilizando esse braço urbano das po-

11. Cidades do Amanhã, São Paulo, Perspectiva, 1995; p.407. A edição inglesa original é de 1988. 
líticas keynesianas do Estado Social pelo desvirtuamento e inibição das localizações empresariais ótimas e, assim, pela decorrente degradação das áreas urbanas centrais. Mas foi ao final da última administração trabalhista britânica que se deu a reconversão de opinião e de escolhas públicas que está nos interessando reconstituir: ao diagnóstico politicamente avançado (para não falar de "esquerda"), de que a nova pobreza oficialmente descoberta pelo establishment, não era uma questão de indivíduos ou famílias estarem abaixo da linha de miséria, mas "estrutural" (segundo relatórios "impregnados de uma juvenil verve marxista") a ruína sistêmica de todo um projeto de época, seguiu-se no entanto uma ênfase de sinal oposto numa política urbana totalmente consagrada ao ressurgimento econômico "a qualquer custo"(sic). Na sequência, a troca de papéis: assim como a orientação e o controle da expansão urbana foram "repentinamente substituídos pela obsessão de encorajar o crescimento", um novo tipo de profissional emergiu da metamorfose do funcionário público local - "por esse tempo, na Inglaterra, quase todas as autoridades dispunham de escritórios de desenvolvimento sob vários nomes" -, o planejador-empreendedor. Faltava no entanto a fórmula salvadora que desse corpo à tamanha obsessão com o crescimento, justificado obviamente pela crença economicista no efeito trickle down da expansão da atividade.

Para variar, a receita veio dos Estados Unidos. E, com ela, outra palavra isca, a famigerada "revitalização urbana", bem como seus derivados não menos famigerados: a "parceria" entre setor público e iniciativa privada, encarregada por sua vez de "alavancar" (outro neologismo ianque - to levarage) investimentos privados com fundos públicos (sempre segundo a descrição de Peter Hall).
Lembra o Autor que o agente-chave, o catalisador de tal reviravolta, foi o empresário de Baltimore, James Rouse. A "rousificação" da América pode ser avaliada pela multiplicação das réplicas de "requalificações" (ainda uma palavra mágica da época) do Inner Harbor de Baltimore e dos esquemas equivalentes do Boston Waterfront, e do Quincy Market, também em Boston, por exemplo no Fisherman's Wharf de São Francisco e por aí afora. Na avaliação - esta, evidentemente crítica - de David Harvey: fenômenos indissociáveis da condição pós-moderna. O roteiro que adota este último é no fundo o da periodização do "espetáculo urbano": a substituição pós-moderna do espetáculo como forma de resistência ou de festa popular revolucionária pelo espetáculo como forma de controle social. ${ }^{12}$

Senão vejamos. Nos anos 60 , a cena das cidades americanas fora invadida por manifestações pelos direitos civis, demonstrações contra a guerra no sudeste asiático e motins de toda espécie, sobretudo nos bairros negros, sendo que boa parte do descontentamento urbano, é bom não esquecer, girava em torno dos projetos "modernos" de habitação e renovação dos equipamentos funcionais típicos, agora ameaçados por distúrbios que estavam se tornando endêmicos. Foi quando, no início dos anos 70, toda essa movimentação acabou sendo "capturada por forças bem diferentes e empregada para fins bem distintos”. Baltimore tornou-se então um instrutivo resumo desta evolução do espetáculo urbano. E aqui o ponto para o qual gostaria de chamar a atenção: a espetacularização bem conhecida de Harbor Place, para não falar nos eventos bem

12. David Harvey, A Condição Pós-Moderna, São Paulo, Loyola, 1992; pp.8892. Original inglês de 89. 
característicos da Baltimore City Fair, considerada pelos interessados um notável sucesso, acabou concentrando o juízo na dimensão mais desfrutável da nova receita - “a arquitetura do espetáculo, com sua sensação de brilho superficial e de prazer participativo transitório, de exibição, de efemeridade e jouissance", etc. Não sem razão, é claro, não só pela estetização bastarda mas pelo impacto nulo sobre a pobreza e demais déficits sociais. E, embora a atenção do observador se fixe mais na colagem da Scarlett Place - que, sobre um fundo neutro de habitações públicas "modernas", justapõe um armazém reciclado do século XIX a uma citação pós-moderna de um casario montanhoso mediterrâneo -, deixando escapar o teor da iniciativa, é preciso lembrar, como aliás o faz Harvey, de forma breve porém precisa, qual o programa de toda a operação: neutralizar os efeitos do assassinato de Martin Luther King em 1968, que ameaçavam a viabilidade dos investimentos - o que levou os líderes locais a procurarem um símbolo em torno do qual construir uma ideia de "cidade como comunidade" em oposição ao de cidade sitiada, como o cidadão comum encarava o centro da cidade e seus espaços públicos. Assim surgiu a Baltimore City Fair como forma de promover o redesenvolvimento urbano, celebrando a "vizinhança" e a diversidade étnica da cidade; o passo seguinte resultou na "comercialização institucionalizada de um espetáculo mais ou menos permanente na construção de Harbor Place", lembrando que os próprios grupos étnicos começaram a lucrar com "a venda da etnicidade", na falta de mercado para sua força de trabalho. Até aqui - para retomar nosso roteiro -, Harvey e o mapa geral da condição pós-moderna, igualmente realçada por Peter Hall, porém acrescida da observação de que tal criação deliberada de um palco cujo protótipo havia sido a "rousifi- cação" de Boston e Baltimore, no limite, a compreensão da intervenção urbana como um processo de produção de locais de sucesso, era o registro e caução espetacular de que "uma nova e radical elite financeira tomava efetivamente posse da cidade, liderando uma coalizão pró-crescimento que habilmente manipulou o apoio público e combinou fundos federais e privados para promover uma urbanização comercial em grande escala". ${ }^{13}$

Sem muito exagero, pode-se dizer que nos Estados Unidos fora lavrada há mais de vinte anos a certidão de nascimento da terceira geração urbanística - terceira, bem entendido, na periodização europeia. E se Peter Hall também está certo quanto à data anglo-americana da inversão de papéis e a consequente conversão do planejamento urbano (dito de última geração duas décadas depois...) num ramo da urbanização empresarial — um ramo "cultural" é claro, como evidenciam os exemplos vistos até aqui, compassado com o novo espírito gerencial do capitalismo-, podemos igualmente acrescentar que tal

13. Peter Hall, op. cit.; p.413. Primeira amostra da receita mágica para uma "parceria criativa", eufemismo hoje enjoativo para a apropriação privada de fundos públicos: tais esquemas "envolviam um desempenho público relativamente muito maior e um maior comprometimento federal: 180 milhões de dólares no caso de Baltimore, contra 58 milhões do município e apenas $22 \mathrm{mi}$ lhões do setor privado. Assim, a subvenção federal, conjugada com uma nova visão de investimento em empreendimento lucrativo por parte do setor público, e a cooperação entre os empreendedores do setor público e privado foram elementos decisivos da nova fórmula" (loc.cit.). Tudo isso há mais de vinte anos, quando a nova "máquina de produzir riqueza" começou a ser azeitada pelos planejadores-empreendedores. Diante da novidade requentada que está sendo resservida atualmente, não deixa de ser pitoresco o relato do mesmo Peter Hall: "a essa altura, alguns planejadores e políticos britânicos começaram a olhar para o outro lado do Atlântico. Pois em fins dos anos 70, segundo a sonora mensagem que vinha dessas bandas, as cidades norte-americanas haviam encontrado uma fórmula mágica. Numa típica reunião anglo-americana de alto nível, o inglês sisudo projetaria slides, mostrando a árida desolação da Liverpool intraurbana; já os exuberantes norte-americanos viriam com fotos de um vibrante centro comercial de Boston, cheio de vida, cor e excitação" (p.412) 
geração só poderia ter entrado em cena programada para operar essas novas coalizões urbanas pró-crescimento.

Dito isso, restava ainda qualificar essa matriz. Não propriamente identificá-la: embora Peter Hall tome o cuidado de não se comprometer com qualquer referência, impossível deixar de reconhecer nos próprios termos de sua apresentação da cidade-empreendimento - a "cidade como máquina de produzir riqueza”, "coalizão pró-crescimento", etc. - a memória muito viva do paper polêmico de Harvey Molotch, "A Cidade como Máquina de Crescimento", publicado pela primeira vez em 1976 no American Journal of Sociology, tanto mais que um ano antes de seu livro sobre As cidades do amanhã, aquela comunicação de Molotch havia sido retomada por extenso num livro em co-autoria John Logan, Urban Fortunes - The political economy of place ${ }^{\mathbf{1 4}}$. Embora os roteiros acima reforcem a percepção de que a Cultura passava a ser um dado essencial na coalizão de classes e interesses responsável pela máquina urbana de crescimento - a porta de entrada para pelo menos duas gerações de arquitetos no caminho de volta à cidade -, não é exatamente este o foco das análises de Molotch, mas o conjunto de condições para por em movimento a máquina urbana de "aumentar rendas agregadas". No entanto - quem diria, com tanta antecedência? - lá estão indicados como ingredientes indispensáveis aos bons negócios: o "orgulho cívico" dos habitantes do lugar e o "patriotismo de massas"15 (retomados, literal-

14. University California Press, 1987; ver também Jonas e Wilson (orgs.), The Urban Grouth Machine, Critical Perspectives Two Decades Later, NY: State University of New York Press, 1999. Devo à Ermínia Maricato a lembrança desse renascimento do debate em torno da tese da Cidade como Máquina de Crescimento.

15. Urban Fortunes... cit.; p.60. mente, como veremos, no receituário apresentado como "planejamento estratégico" no Habitat II ${ }^{16}$ ).

Embora se saiba que as cidades modernas sempre estiveram associadas à divisão social do trabalho e à acumulação capitalista; que a exploração da propriedade do solo não seja um fato novo, e que haja - como mostrou à exaustão Lefèvre e depois toda a geografia humana recente - uma relação direta entre a configuração espacial urbana e a produção ou reprodução do capital, como estamos vendo, há algo de novo a registrar nessa fase do capitalismo em que as cidades passaram elas mesmas a ser geridas e consumidas como mercadorias. Daí a novíssima luz retrospectiva que a redescrição da cidade-empreendimento segundo Peter Hall lança sobre a atual revisão da cidade-máquina-de crescimento formulada há quase vinte e cinco anos por Molotch. Tese elaborada a partir de uma constatação paradoxal: a cidade-negócio está ancorada numa pseudomercadoria, o solo, um outro nome para a natureza, que aliás não foi produzida pelo homem, muito menos para ser vendida num mercado. A "tese" em questão nada mais é portanto do que uma explicitação da contradição recorrente entre o valor de uso que o lugar representa para os seus habitantes e o valor de troca com que ele se apresenta para aqueles interessados em extrair dele um benefício econômico qualquer, sobretudo na forma de uma renda exclusiva. A forma da cidade é determinada pelas diferentes configurações deste conflito básico e insolúvel. À primeira vista, uma história tipicamente americana, pois, em nenhuma região do mundo, o solo foi

16. Cf. Manuel Castells e Jordi Borja Local y Global, Madri: Taurus, 1997; ou o capítulo V, traduzido e publicado na Revista Novos Estudos $\mathrm{n}^{\circ} 45$, SP, Cebrap, 1996: "As cidades como atores políticos"; pp.152-166. 
considerado tão indiscutivelmente o alvo primordial da especulação capitalista. Que a cidade tenha outra finalidade que não a de atrair o comércio, incrementar o valor dos imóveis e, portanto, pura e simplesmente crescer, é uma coisa que jamais passou pela cabeça dos próceres da nação, observou certa vez Lewis Mumford, recapitulando a urbanização americana de 1850 a $1930^{\mathbf{1 7}}$. Forçando um pouco a nota (mas não muito), Molotch chega a dizer que até mesmo o zelo independentista dos Founding Fathers fora motivado em boa parte pela especulação com terras no oeste. ${ }^{18}$

Em duas palavras, a ideia de cidade como growth machine pode ser assim resumida: coalizões de elite centradas na propriedade imobiliária e seus derivados, mais uma legião de profissionais caudatários de um amplo arco de negócios decorrentes das possibilidades econômicas dos lugares, conformam as políticas urbanas à medida em que dão livre curso ao seu propósito de expandir a economia local e aumentar a riqueza. A fabricação de consensos em torno do crescimento a qualquer preço - a essência mesmo de toda localização - torna-se a peça chave de uma situação de mobilização competitiva permanente para a batalha de soma zero com as cidades concorrentes. Uma fábrica por excelência de ideologias, portanto: do território, da comunidade, do civismo, etc. Mas sobretudo, a fabulação de senso comum econômico, segundo o qual o crescimento enquanto tal faz chover empregos. No coração dessas coalizões, a classe rentista de sempre, hoje novamente na vanguarda dos "movimentos urbanos": in-

17. Apud Logan e Molotch, op. cit..; p.57.

18. Cf. H. Molotch, “Growth Machine Links: Up, Down, and Across”, em Jonas e Wilson cit.; p.249. corporadores, corretores, banqueiros, etc., escorados por um séquito de coadjuvantes igualmente interessados e poderosos, como a mídia, os políticos, universidades, empresas esportivas, câmaras de comércio e, enfim, nossos dois personagens desse enredo de estratégias: os planejadores urbanos e os promotores culturais. Com a retomada da hegemonia americana, vulgarmente conhecida como "globalização", o modelo máquina-de-crescimento generalizou-se sob pretexto de responder às mesmas pressões competitivas em torno do capital escasso e nômade, na verdade atendendo aos imperativos (políticos) da cultura anglo-saxônica dos negócios ${ }^{19}$, a ponto de converter num dado natural a convicção de que as cidades devem ser geridas não "like business", mas antes "for business" (ainda segundo Molotch). Portanto, não há injustiça em reprisar: o famoso pacote catalão de estratégias urbanas tem muito de déjà vu. ${ }^{20} \mathrm{Ou}$ por outra, tudo se passa como se a transnacionalização produtiva e financeira, ao contrário do que se poderia prever, em função do acentuado localismo das máquinas urbanas de crescimento, acabasse conferindo - justamente devido ao redirecionamento dos Estados Nacionais, cada vez mais socialmente esvaziados e deslegitimados, no rumo de uma simbiose ainda mais estreita com o mundo dos negócios a serem publicamente (e acintosamente) "alavancados" - uma segunda

19. Cf. John Gray, Falso Amanhecer - os equívocos do capitalismo global, Rio de Janeiro: Record, 1999.

20. A aproximação soa ainda menos arbitrária se pensarmos que Manuel Castells, antes criticado por Hall, como um dos representantes do "urbanismo marxista" dos anos 70, aos quais opunha o pragmatismo dos urbanistas-manager da cidade-empreendimento, acabou por escrever com este, a quatro mãos, um livro sobre Technopoles of World, publicado em 1994 (Londres: Routledge). 
juventude cosmopolita às paroquiais coalizões urbanas pró-crescimento.

Evidentemente, é quase supérfluo dizer quem ganha e quem perde, ou seja, quais os primeiros a rebaixar os seus próprios padrões de qualidade civil. Não é necessária muita pesquisa - aliás abundante no livro de Molotch e Logan - para concluir que todo incremento de crescimento local, mantidas as correlações sociais vigentes, implica numa transferência de riqueza e chances de vida, do público em geral para os grupos rentistas e seus associados. No caso, mais aparatoso e quase consensual, por exemplo, da Cultura (quem seria contra tal aprimoramento coletivo?) não é menos evidente essa troca desigual: "o processo de construção da cidade distribui esculturas, museus e edifícios de alto padrão atraindo aqueles que têm condições de escolher onde viver, trabalhar, e gozar sua afluência. As zonas favorecidas incorporam, como lugares, o capital cultural que forja não somente seu futuro privilegiado, mas reduz o futuro das áreas menos favorecidas". ${ }^{21}$ Trata-se claramente de uma estratégia autodestrutiva, e, mesmo assim, a corrida rumo ao desastre continua, como é próprio da natureza de um sistema que hierarquiza e estratifica, porque o seu desenvolvimento não pode deixar de ser desigual - enfim, cidades mundiais demandam longos ciclos históricos de polarização sistêmica, não foram geradas por pacotes de vantagens competitivas planejadas em agências de consultoria.

Dá assim para imaginar a força avassaladora dessa máquina urbana de propaganda, ainda mais se dispõe de meios para chantagear com a sempre invocada geração iminente de empregos. Aqui, novamente, o lugar da

21. H. Molotch, “Growth Machine...”, em Jonas e Wilson cit.; p.258. união simbiótica entre rentiers, planejadores urbanos e intermediários culturais na construção de "consensos" cívicos. No centro, para variar, a Cultura, cujo consumo, na forma de refinamento artístico ostensivo, é a melhor garantia de que o clima para os negócios é saudável. Assim, curadores de museus precisam demonstrar que suas instituições (ou melhor, organizações) atraem multidões que multiplicam os negócios, dos gadgets de toda ordem às exposições blockbuster - de preferência, como até Molotch repara, "anything Cézanne"; o mesmo para universidades, cuja sobrevivência institucional depende cada vez mais de sua atitude cooperativa diante do mundo dos negócios, etc. Enfim, não se trata de constatar a colonização da animação cultural (que aliás já nasceu colonizada, como o próprio nome indica) pela Máquina de Crescimento, mas sobretudo a operação inversa: o novo combustível sem o qual a coalizão não fabrica os consensos de que necessita, pois se trata de uma máquina ideológica acionada pelos que administram tanto a construção física quanto a ideacional dos recursos capazes de impulsionar o desenvolvimento dentro e através dos "lugares" da cidade, apropriadamente denominados urban imagineers ${ }^{22}$. Nestas circunstâncias não é de estranhar que o arquiteto-urbanista tenha se tornado um dos operadores chaves desta máquina, reunindo num só personagem o manager (o planejador-empreendedor identificado por Peter Hall) e o "intermediário cultural" - fração de classe fornecedora de bens e serviços simbólicos, cuja trajetória ascendente é reveladora do atual culturalismo de mercado. Bourdieu

22. A designação, citada por Molotch, é de John Short, "Urban imagineers: boosterism and imagination of cities", em Jonas e Wilson cit.; pp. 37-54. 
foi o primeiro a assinalar a existência deste personagem ${ }^{23}$, ao mesmo tempo intermediário e empresário cultural, no qual Mike Faetherstone por sua vez reconheceu um dos principais agentes da gentrification ${ }^{\mathbf{2 4}}$.

$*$

Por essas e outras considerações, quando se fala hoje em dia, a torto e a direito, em "fazer cidade", tamanho eufemismo vale bem a pergunta: quem de fato "faz a cidade"? A resposta, ao menos a partir dos anos 90, parece inequívoca: naturalmente, as grandes empresas com as mediações de praxe, é claro. Por isso, a mesma paisagem por toda a parte, ou melhor, sem contar os simulacros na periferia, as mesmas landscapes of power descritas por Sharon Zukin em cidades globais como Nova York e Londres: não há nada de surpreendente nisto, pois o redesenvolvimento das áreas centrais nas duas cidades não por acaso se encontraram nas mãos das mesmas instituições financeiras, das mesmas megaincorporadoras, dos mesmos escritórios do star system, que por seu turno preparam o terreno por encomenda das matrizes multinacionais de sempre. ${ }^{25} \mathrm{E}$ assim por diante, vão as grandes corporações multinacionais, tratando de nos persuadir que os verda-

23. Cf. Bourdieu, La Distinction, Paris: Minuit, 1979; cap.VI.

24. Cf. Mike Faetherstone, Cultura de Consumo e Pós-modernismo, São Paulo: Studio Nobel, 1995.

25. Cf. Sharon Zukin, "The city as a landscape of power", in Leslie Budd e Sam Whimster, Global Finance and Urban living, London: Routledge; 1992; pp.203-205. Cf. também, da mesma autora: Landscapes of power. From Detroit to Disney World, University of California Press, 1991; The Cultures of Cities, Cambridge, Blackwell, 1995; e "Paisagens Urbanas Pós-Modernas”, em Revista do Patrimônio n²24,1996; pp. 205-219. deiros protagonistas da cena mundial são - quem diria... — as cidades, ou melhor, cidades cuja configuração seja propícia à valorização patrimonial que mais interessa a tais firmas no presente estágio de transnacionalização produtiva. Rentabilidade e patrimônio arquitetônico-cultural se dão as mãos, nesse processo de revalorização urbana - sempre, evidentemente, em nome de um alegado civismo (como contestar?...). E para entrar neste universo dos negócios, a senha mais prestigiosa - a que ponto chegamos! (de sofisticação?) — é a Cultura. Essa a nova grife do mundo fashion, da sociedade afluente dos altos serviços a que todos aspiram.

\section{Gentrificação estratégica}

Pois é: da Carta de Atenas à corretagem intelectual de planos de gentrificação, cujo caráter de classe o original inglês (gentry) deixa tão vexatoriamente a descoberto. Daí a sombra de má consciência que costuma acompanhar o emprego envergonhado da palavra, por isso mesmo escamoteada pelo recurso constante ao eufemismo: revitalização, reabilitação, revalorização, reciclagem, promoção, requalificação, até mesmo renascença, e por aí afora, mal encobrindo, pelo contrário, o sentido original de invasão e reconquista, inerente ao retorno das camadas afluentes ao coração das cidades. Como estou dando a entender que o planejamento dito estratégico pode não ser mais do que um outro eufemismo para gentrification, sem no entanto afirmar que sejam exatamente a mesma coisa - quem sabe a sua apoteose: uma cidade estrategicamente planificada de $\mathrm{A}$ a $\mathrm{Z}$ nada mais seria, enfim, do que uma cidade inteiramente gentrificada -, preciso abrir um parêntese a 
respeito deste tópico, que se tornou um dos pontos de honra da diluição culturalista da espoliação urbana, pois afinal o que importa nisto tudo é sempre determinar quem sai e quem entra, só que agora se trata de uma apropriação do espaço legitimada pelo upgrading cultural. ${ }^{26}$

Digamos, retomando o argumento, que a gentrificação é, em geral, uma resposta específica da máquina urbana de crescimento a uma conjuntura histórica marcada pela desindustrialização e consequente desinvestimento de áreas urbanas significativas, a terciarização crescente das cidades, a precarização da força de trabalho remanescente e sobretudo a presença desestabilizadora de uma underclass fora do mercado. E nessa transição dramática também se põe em funcionamento, com a mesma eficiência, a máquina de fabricar consensos. Como logo perceberam Molotch e Logan, a longa marcha dos novos pioneiros

26. Embora o termo "gentrificação" tenha sido adotado em 1963, por Ruth Glass, para descrever o processo de retorno de parte da classe média para regiões centrais de Londres, que passam a ser revalorizadas, alterando, portanto, o perfil social das mesmas, hoje é utilizado com diferentes acepções. Pretendem alguns autores, em especial Neil Smith, que tal denominação tem na atualidade um sentido bastante abrangente, não mais designando um movimento esporádico e muitas vezes espontâneo, mas absolutamente intencional e dirigido, isto é, trata-se de um procedimento que se generalizou e se transformou numa "estratégia urbana global", mesmo quando se pretende estar apenas diante de um renewal ou uma simples "regeneração" do tecido urbano (eufemismo não por acaso biomédico). Na verdade, uma política urbana neoliberal que não ousa dizer seu nome, e que visa antes de tudo desestigmatizar certas regiões para atrair investidores através de estratégias ao mesmo tempo culturais e econômicas, produzindo paisagens urbanas que as classes médias e altas podem consumir, criando assim uma verdadeira conquista por uma coalizão de classes mais à vontade e confortáveis no desfrute da desigualdade social. Volto a enfatizar que um ingrediente importante desta política decorre, sem dúvida, da centralidade que a cultura passa a ter nestes processos de "requalificação". O que, de certa forma, já está presente no exemplo de Ruth Glass: a revalorização de toda uma região de Londres que é concomitante à reviravolta na abordagem da cidade, quando todo um patrimônio histórico e arquitetônico urbano passa a ser visto como "valioso" e parte de uma "ambiência cultural" que "enobrece" o lugar, embora nem sempre venha acompanhada de uma política preservacionista. urbanos foi saudada desde o início pela coalizão de sempre entre mundo dos negócios, mídia e burocracia pública. Segundo nossos autores, tal celebração dava a entender muito claramente que nenhuma violência contra os novos ricos seria tolerada, que as agências reguladoras não disciplinariam corretores e incorporadores, e, sobretudo, que aqueles que vendessem suas moradias aos forasteiros não tinham porque se envergonhar perante os vizinhos sem nada de seu para barganhar. ${ }^{27}$

O mais conhecido e reprisado modelo desta associação hegemônica entre especuladores, políticos e urban imagineers não por acaso encontra-se em Nova York, no processo de gentrificação do SoHo, inicialmente através do incentivo à reciclagem dos lofts pela comunidade local de artistas - essa a novidade na articulação de capital e cultura na remodelagem da cidade, realçada pelo estudo pioneiro de Sharon Zukin²8. Para variar — ou melhor, pela primeira vez de modo exemplar, a partir dos anos 70 -, reabilitava-se a área sinistrada por uma operação "concertada" (como dirão os ideólogos catalães) de requalificação dos espaços desativados das velhas manufaturas, convertidos em galerias ou mesmo residências de artistas, boutiques, restaurantes ditos sofisticados, etc., e consequente migração forçada dos antigos moradores e reconversão dos raros proprietários remanescentes, travestidos de intermediários de altos negócios imobiliários. Novos padrões de gosto e consumo difundiam a sensação

\section{Op. cit., p.116.}

28. Loft Living. Brunswick, Rutgers University Press, 1989 (a primeira edição é de 1982). David Harvey deu-lhe os devidos créditos ao prefaciar a edição britânica de 1988. Ver ainda do mesmo Harvey outro comentário a respeito em A Condição Pós-Moderna, ed. cit.; p.82. 
reconfortante de que uma vida de artista, desta vez reconciliada, com a sociedade, podia ser o apanágio de uma nova vanguarda da burguesia - é claro que o conjunto movido a transgressões sistemáticas da legislação com a mal disfarçada aquiescência da administração local.

Aí o embrião de uma mudança emblemática: à medida que a cultura passava a ser o principal negócio das cidades em vias de gentrificação, ficava cada vez mais evidente para os agentes envolvidos na operação que era ela, a cultura, um dos mais poderosos meios de controle urbano no atual momento de reestruturação da dominação mundial. Mais ou menos nos seguintes termos, como se pode ler num estudo posterior de Zukin acerca das estratégias culturais de redesenvolvimento urbano, cujo miolo novamente reside na propagação da imagem de um centro de inovação, qualquer que ela seja, dos serviços financeiros à segurança máxima dos públicos solventes ${ }^{29}$ : é preciso distinguir acima do alicerce formado pelos fatores econômicos clássicos sobre os quais se edifica uma cidade - terra, trabalho e capital - pelo menos mais três camadas de trocas desiguais, e, no caso, "simbólicas". A primeira delas consiste na manipulação de linguagens simbólicas de exclusão e habilitação (entitlement): o "visual" de uma cidade, bem como a maneira pela qual ela se deixa por assim dizer manusear, seu aspecto "tátil", podemos acrescentar, refletem decisões sobre o quê, e quem, pode estar visível ou não, decisões em suma sobre ordem e desordem, o que acarreta algo como uma estetização do poder, da qual o desenho arquitetônico é um dos instrumentos mais aparatosos. ${ }^{30} \mathrm{Na}$ segunda

29. Cultures of Cities cit.; cap.1.

30. A expressão inglesa entitlement admitiria aqui uma especificação terra-a-terra e por isso mesmo mais local e subdesenvolvida, o que não seria em camada, deparamos de novo, não por acaso, com a máquina de Molotch: é que a economia simbólica da cidade também é comandada pela habilidade dos "place entrepeneurs" (aos quais foram se juntar hoje os últimos ideólogos do "lugar") em lidar com os símbolos do crescimento, e sua promessa de empregos e negócios. Por último, o setor mais tradicional, atualmente reativado no ritmo do capitalismo turbinado americano, a aliança entre os círculos de negócios e os "advogados da cidade" - quer dizer, a cobertura do multicolorido edifício do Terceiro Setor -, a qual, por uma combinação eficiente de mecenato e orgulho cívico, cimentado pelo desejo de se apresentar como um novo patriciado, se encarregará de fazer com que se multipliquem museus bombásticos, parques idem e complexos arquitetônicos que assegurem a quem de direito que se está entrando numa "world-class-city". Pois é esta simbiose de imagem e produto $^{31}$, que caracteriza a cidade-empresa-cultural perseguida pela terceira geração urbanística.

si mesmo descabido à vista da dualização crescente das sociedades centrais. Comentando o entitlement approach (enfoque da habilitação) proposto pelo economista indiano Amartya Sen para o problema da pobreza endêmica, Celso Furtado observou que é justamente o processo de habilitação (por títulos de propriedade ou inserção qualificada nos processos produtivos) que se encontra bloqueado nas sociedades subdesenvolvidas: "isso é evidente com respeito a populações rurais sem acesso à terra para trabalhar ou devendo pagar rendas escorchantes para ter este acesso. O mesmo se pode dizer das populações urbanas que não estão habilitadas para ter acesso à moradia. As instituições que permitem a concentração em poucas mãos da formidável valorização das terras urbanas respondem pela miserabilidade de grandes massas da população. A pobreza em massa, característica do subdesenvolvimento, tem com frequência origem numa situação de privação original do acesso à terra e à moradia. Essa situação estrutural não encontra solução através dos mecanismos de mercado", A Construção Interrompida, São Paulo: Paz e Terra, 1992; p.55. $O$ vínculo entre a Lei de Terras de 1850 e o fim de linha urbano em que nos debatemos, encontra-se exposto por extenso no capítulo de Ermínia Maricato do livro citado A cidade do pensamento único: "As ideias fora do lugar e o lugar fora das ideias...".

31. Na fórmula de Sharon Zukin, op cit.; p.8. 
Não seria o caso agora de repertoriar os inúmeros exemplos novaiorquinos de gentrificação estratégica, se é que se pode falar assim, embora seja disso que se trata. O princípio da máquina cultural de crescimento não varia muito, como se poderia verificar noutra requalificação famosa, a de Battery Park, com o roteiro de sempre: concebido em meados dos anos 60 como uma nova área de habitação em Manhattan, destinada em princípio a várias camadas sociais, foi aos poucos se transformando num vasto projeto de gentrificação impulsionado por uma sucessão de crises (algumas forjadas) e medidas governamentais de "socorro", com o seu habitual cortejo de comércio chic e amenidades culturais, entre as quais um verdadeiro festival de arte pública (ou o que atualmente passa por tal), no qual se consagraria a união entre Arte e Urbanismo, devidamente emoldurada por uma fantasia kitsch, segundo a qual o encontro de terra e água que ali se celebrava descendia da mesma nobre estirpe de Veneza, Constantinopla e Petersburgo. ${ }^{32}$

A associação é quase imediata com outra experiência simétrica, embora londrina, criada também, em plena década de 70, com o intuito de construir habitações, inclusive preferencialmente subsidiadas, para pessoas de baixa renda, numa região central que se achava desativada e degradada: o velho porto de Londres, com seus armazéns, do outro lado do Tâmisa, bem em frente à City. O plano, proposto pelo Joint Comitee, não agradou ao governo central que acabou criando a famigerada LDDC que não tinha por função senão impedir qualquer regulamentação restritiva ao mercado. O resultado é conhecido: especulação imobiliária desenfreada, tornando o local um reduto de 32. Cf. Rosalyn Deutsche, Evictions, Cambridge, MIT, 1996; pp.79-93. yuppies nos anos 80, com os preços dos terreno valorizadas em até $2.000 \%$, seguida de uma baixa vertiginosa, falência de todo tipo, inclusive da Olympia and York (casualmente, responsável tanto pela construção de Battery Park quanto de um imenso complexo multifuncional em Cannary Wharf). Todo o tipo de chantagem (até a família real tinha propriedades nas ilhas) e logo o Estado entrava em cena. Hoje é uma outra cidade dentro de Londres: centro empresarial, sede das grandes corporações e de boa parte da mídia, e dos altos serviços, sem contar habitações de altíssimo padrão. O de sempre, com direito aos mais luxuosos ambientes, inclusive nas estações de metrô, projetadas pelos mais festejados arquitetos, como Norman Foster. Tudo bem calculado para dar aos que ali chegam a certeza de que estão entrando num espaço urbano diferenciado - diriam os gerentes urbanos de plantão: “altamente qualificado". A simetria não é fortuita: não só porque Manhattan e Docklands/City são hoje os grandes centros financeiros de duas das três maiores Global Cities, mas tentam através de todos os tipos de estratagemas expandir os efeitos destas ilhas privilegiadas para a cidade como um todo, que vai se valoriozando e - por que não? - gentrificando. Veja-se por exemplo a grande operação em Londres East, em franca efervescência comandada pela recente jubilee line; ou em Southwark — na região sul do Tâmisa, pelo mais aplaudido, neste momento, $\mathrm{Mu}$ seu Europeu, a Nova Tate Gallery.

Voltando a NY, seria o caso sim de completar o raciocínio, observando algo aparentemente trivial, mas que na verdade faz tempo deixou de ser, o fato de que áreas gentrificadas são áreas altamente vigiadas, e segundo a gramática estetizante mencionada há pouco a propósito das "habilitações" bloqueadas — da moradia à simples perma- 
nência num parque requalificado. Este último é o módulo mais simples do mecanismo de subordinação de um espaço público ao controle privado, para variar na forma de alguma ONG criada ad hoc pela coalizão local de reabilitadores urbanos: redesenha-se o local; programa-se eventos culturais; abre-se um café ou coisa que o valha igualmente chic, completando-se o serviço com uma pequena horda de seguranças. E por aí vai, a cada unidade mais complexa de intervenção, até se alcançar, quem sabe, toda a cidade que importa, seu enclave propriamente global. Chegamos enfim ao que já foi chamado de "estetização do medo"33 e que vem a ser a mola secreta do súbito interesse manifestado pelas elites globais pelo espaço público, sobre o qual se puseram sintomaticamente a tagarelar: não há mecenas que se preze que não patrocine alguma área pública, com o zelo ancestral demandado por essa nova onda de enclosures, como nos tempos da acumulação primitiva.

A esta altura é bom não perder de vista a origem militar da palavra estratégia, que da esfera semântica da guerra econômica foi transplantada, com involuntária precisão, para um urbanismo que pelo menos confessa precisar de adversários, aliás facilmente identificáveis. Assim sendo, penso ser o caso de incluir na "cidade revanchista”, descrita por Neil Smith ${ }^{34}$, a gentrificação estratégica de que estamos falando. A designação não deve surpreender numa era de revanche do Capital em todas as frentes - cuja magnitude deve se explicar pelo Grande Medo que se seguiu à explosão dos anos 60/70. Na arena propriamente urbana, revanche contra trabalhadores

33. Pela mesma Sharon Zukin, no livro citado há pouco.

34. The New Urban Frontier, Londres, Routledge, 1996. precarizados, imigrantes, sem-teto, etc., enfim, todo tipo de classe perigosa que possa ameaçar o sono dos vencedores de ontem. Por cidade revanchista Neil Smith entende mais especificamente a retomada agressiva das gentrificações depois das grandes falências do fim dos anos 80, mas sobretudo como reação à deterioração urbana provocada pela primeira onda de desregulações e cortes nos programas sociais. Não é difícil perceber, todavia, que o revanchismo que anima sem disfarce as gentrificações estratégicas é expressão de uma escalada mais extensa e profunda na guerra social contemporânea, cristalizada, entre outras patologias da atual hegemonia global, numa espécie de novo senso comum penal - criminalização da pobreza e normalização do trabalho precário-, cuja manifestação urbana também pode ser identificada numa sorte de princípio da inviolabilidade do espaço público, por isso mesmo submetido a um estrita vigilância privada. ${ }^{35} \mathrm{Uma}$ "nova doxa punitiva" alimenta a progressiva substituição do Estado Social pelo Estado Penal (algo em torno de 0,7\% da população americana está encarcerada e, dela, $80 \%$ são negros) - por sua vez monitorada pelo complexo indústria-carceral, um outro ramo muito próspero no capítulo das privatizações -, tanto quanto a estetização cultural do medo induzida pela atual fase de gentrificação. Ora, outra ironia, desta vez semântica, mas em sintonia com os esvaziamentos que estamos acompanhando, consiste em batizar com o nome de civilidade - nada mais enfaticamente cultural - essa maré punitiva que saúda cada lance de aprofundamento do novo Estado Penal como um gesto de audácia cívica contra o amolecimento da vontade polí-

35. Cf. Loïc Wacqant, “Ce vent punitif qui vient d'Amérique”, in Le Monde Diplomatique, abril, 1999. 
tica dos governantes. Não há dispositivo de segurança que não passe então a representar alguma força civilizatória. Como a "tolerância zero" do prefeito Giuliani, para dar o exemplo mais corrente: assim, segundo o atual administrador de Nova York, "numa cidade civilizada, as ruas não são lugar para dormir, as pessoas devem usar quartos". ${ }^{36}$

Não surpreende que nessas circunstâncias o jargão da civilidade tenha impregnado a montagem das novas estratégias urbanas, afinal ambos têm a mesma origem no management empresarial. E pelo padrão Giuliani de civilidade podemos imaginar o que se passa hoje no interior de uma empresa-cidadã. E, por extensão, nos espaços gentrificados de uma cidade-empresa-cultural, que deveria então ser redescrita por um outro ângulo: não só como cidade-negócio, mas igualmente como uma cidade "polida" em todas as suas engrenagens - de uma vendedora de boutique a um transeunte benévolo como se vivesse numa ONG de asfalto - como uma só empresa regida por um script único de atendimento ao cliente, como em qualquer lanchonete de fast-food. Nas cidades globais certamente causa a melhor das impressões, razão a mais para se replicar o modelo nos enclaves da periferia...

\section{Os dois turnos do Cultural Turn}

É bom não perder de vista que está nos interessando desde o início esclarecer o papel preponderante da gestão cultural nesse novo receituário de planificação urbana ostensivamente empresarial. Em princípio, não era para ser

36. Citado por Renan Antunes de Oliveira, "Nova York anuncia ofensiva contra sem-teto”, O Estado de São Paulo, 22.11.99. assim tão evidente que sem investimentos de porte compatível na área cultural, as cidades teriam sua governabilidade posta em dúvida, pela comunidade de negócios... Mas tampouco a velha guarda liberal-burguesa e sua contraparte social-progressista poderiam prever que os templos urbanos da cultura só renasceriam, reforçados em sua legitimidade, caso pudessem alegar os grandes números de sucesso numa estratégia competitiva de inserção global. Pois foi o que se deu, como já sabemos, mas ainda não explicamos por extenso: a resistência identitária dos lugares da memória e da produção do sentido, entranhada na urbanidade então redescoberta com a implosão da idade moderna da feiúra - como diziam os franceses depois de 68 -, reposta tal qual, na sua alegada autenticidade cultural tomada ao pé da letra, na engrenagem da máquina urbana de crescimento. Estou me referindo ao seu papel de "âncora" do viés culturalista nas novas estratégias de planificação, em princípio destinadas a conter a desordem urbana até então estetizada pelos representantes mais cínicos ou mais bisonhos, e cujas metamorfoses precisamos agora periodizar, atentando para as reviravoltas e confluências que culminarão na cidade-empresa-cultural.

Aludi páginas atrás à existência de algo como um segundo turno no interior mesmo da virada de época que em princípio estaríamos vivendo, batizada de cultural turn. Como esta guinada interna não parece nem um pouco evidente e é decisiva para o meu argumento, gostaria de me estender um pouco a respeito. Acredito que ela torne um pouco mais compreensível o mecanismo de fundo que governa as convergências inesperadas na origem do novo mainstream urbano.

Não viria ao caso rastrear agora as origens da própria expressão cultural turn. De fato me interessam 
muito mais as circunstâncias de nascimento, ascensão e auge do primeiro termo da fórmula, o "cultural", assim mesmo, substantivado, e agora no seu estágio terminal como um item administrativo. Mesmo assim, e sem a menor intenção de fazer história das ideias, não seria demais relembrar que a denominação cultural turn, surgiu nos meios de esquerda dos campi anglo-americanos, nos anos 80, designando uma dessas mudanças ditas revolucionárias de paradigma, graças à qual tudo teria se tornado "cultural"37, suficientemente abrangente para dar conta tanto da economia (como uma questão de retórica), quanto da cidade-colagem metafórica (na expressão consagrada por Collin Rowe) dos contextualistas. Também seria o caso de lembrar que, a partir de certo momento, a fórmula tornou-se um sinônimo mais confiável para o desgastado pós-moderno, a ponto de Fredric Jameson, por exemplo, intitular sem maiores explicações Cultural Turn sua mais recente coletânea de escritos (1998) sobre o assunto. Tão ampla, tal ruptura de paradigma, e sua correspondente denominação atualizada, de modo a abarcar, na mesma convicção de que os tempos são outros (mesmo que não a ponto de esgotar o Projeto Moderno ainda inconcluso), um adversário empedernido do pós-modernismo como Jürgen Habermas, cujo paradigma comunicacional, que envolve linguagem e significação pragmaticamente compartilhada, é apenas um

37. Mais especificamente nos Departamentos de Humanidades e Ciências Sociais, e não antes dos anos 80 , muito embora as hibridizações que lhe deram origem datem da década anterior, como o transplante americano do pós-estruturalismo francês - para o qual, como se sabe, não havia nada fora do texto, ou do discurso - e sua fusão com as derradeiras metamorfoses do linguistic turn anglo-americano, das revoluções epistemológicas de Thomas Kuhn aos jogos de linguagem do segundo Wittgenstein, e por aí afora até à cristalização do sentimento anti-establishment acadêmico de que afinal "everything is culture". outro nome para a mesma rotação histórica invocada pelos seus inimigos culturalistas.

Não param por aí as convergências, e esta agora nos interessa mais de perto. Mesmo Jameson, que publicou uma longa e reticente resenha a propósito da voga dos Estudos Culturais, se esqueceu de reparar que estavam ambos e todos acionando a mesma manivela do cultural turn. Como Jameson vinha há tempos verificando, ao seu próprio modo, a pertinência do referido tournant cultural do capitalismo avançado, não poderia deixar de concluir que a cultura tornara-se de tal maneira coextensiva à vida social em geral que o "cultural" e o "econômico" teriam passado um no outro e já significavam a mesma coisa. ${ }^{38}$ Por seu lado, os principais formuladores dos Cultural Studies também nos asseguram que a cultura se tornou central na conformação de "fenômenos sociais totais" (utilizando os termos da antropologia de Mauss, hoje novamente em voga na discussão dos processos civilizatórios, e sabemos que a principal fronteira deles é a urbana), e igualmente extensiva, a ponto de ter convertido a economia política da reprodução capitalista numa economia cultural. ${ }^{39}$ À primeira vista, uma enormidade; entretanto ainda não foi dita a última palavra (materialista por certo) acerca da economia baseada na informação. Fica por enquanto ape-

38. Cf. Fredric Jameson, "Periodizando anos 60 ", in Heloisa Buarque de Holanda, Rio de Janeiro, Rocco, 1991; do mesmo autor, Pós Modernismo: A lógica cultural do capitalismo tardio, São Paulo, Ática, 1996. A edição mencionada do Cultural Turn é da Verso, Londres, 1998. Para um comentário mais detalhado deste processo de aculturação da realidade social segundo Jameson, cf. meu "Cultura da Cidade..." cit. Ou ainda "O cultural turn no discurso sobre a cidade”, em Rua n. especial, NUDECRI/UNICAMP, 1999; pp.89-100.

39. Cf. Stuart Hall, "The centrality of culture", in Kenneth Thompson (org.) Media and Cultural Regulation, Londres, Sage, 1997. Ver ainda as observações críticas de John Kraniauskas, "Globalization is ordinary”, in Radical Philosophy, n.90, 1998. 
nas a constatação de que a nova esquerda anglo-americana é antes de tudo uma esquerda cultural, e que por isto mesmo justifica, involuntariamente, sua presença politicamente nula no mundo realmente existente do trabalho.

Ora, se assim é, quer dizer, se é fato que há uma ou duas décadas a nova new left está convencida de que a lógica do capitalismo contemporâneo tornou-se cultural, seria então o caso, para início de conversa, de relembrar certas circunstâncias da sempre relegada década de 70 (talvez mais decisiva que o estopim dos sixties), a começar pela indispensável constatação de que foi nada mais nada menos do que a própria direita quem primeiro proclamou, nos anos 70 precisamente, que de fato era preciso reconhecer que o capitalismo padecia de contradições, mas que estas eram de ordem cultural. O clássico de Daniel Bell, As Contradições Culturais do Capitalismo é de 1976. Dele procede, por exemplo, a deixa para o diagnóstico neoconservador, repisado até hoje, segundo o qual o risco maior que o sistema corria era o da "ingovernabilidade", devido justamente a uma "adversary culture" solta nas ruas.

Por onde se vê que já estava armado o cenário que atribuiria à cultura um papel central na governabilidade do aparato de dominação. O perigo iminente de "ingovernabilidade" era atribuído a uma sobrecarga intolerável de pressões, que o oficialismo de hoje chamaria de populismo macroeconômico, mas que na época eram postas na conta de uma inflação de exigências descabidas apresentadas a um Estado Social que a desaceleração do crescimento econômico começara a desacreditar — exigências que no entanto pareciam ultrapassar o plano esperado das compensações materiais para elevar-se ao patamar mais inquietante da perda de confiança na autoridade moral das instituições. Ou seja, seu infalível sexto sentido ideológi- co ditou-lhes a inversão de praxe: a crise de governabilidade seria, em última instância, uma crise cultural; eram no fundo as orientações normativas de uma cultura hostil em flagrante antagonismo com o velho ethos produtivista do capitalismo, que inflavam a enorme pressão reivindicativa naquela antevéspera da contraofensiva Reagan/ Thatcher. ${ }^{40}$

Pode-se dizer que a nova esquerda que entrava em cena nos anos 70 foi aos poucos tomando ao pé da letra este diagnóstico de cabeça para baixo, porém com sinal trocado: de fato o que contava mesmo era a cultura antagônica que se estava cristalizando por toda a parte na esteira de 68 , mas sobretudo - como admitia a direita ainda na defensiva, diante da indisciplina que se alastrava do Vietnã às greves selvagens na Europa Continental — seu poder mobilizador estava demonstrando que algo na base material do capitalismo se alterara em profundidade, e com isto, o conflito básico das sociedades capitalistas. Aqui o primeiro turno do cultural turn, que só restrospectivamente será reconhecido, e reapropriado, como tal.

O roteiro é conhecido, mas não custa repassá-lo do ângulo de agora. Segundo consta em mil e uma versões, a novidade do nosso tempo emergiu à luz do dia em Maio de 1968, a maior greve de massa na história das sociedades industriais avançadas. Há quem veja naquela brecha histórica, que se fechou apenas entreaberta, algo como o

40. Cf. Claus Offe, "A ingovernabilidade: sobre o renascimento das teorias conservadoras da crise", in Problemas Estruturais do Estado Capitalista, Rio de Janeiro, Tempo Brasileiro, 1984 (a edição alemã original é de 1979); Jurgen Habermas "Les néo-conservateurs contre la culture", Praxis Internationale, jan. de 1983, republicado num Temps Modernes do mesmo ano. Ainda sobre os equívocos da antinomia neoconservadora entre modernização econômico-social e modernização cultural, Jurgen Habermas "Modernidade versus Pós-Modernidade”, in Arte em revista n.7, São Paulo, CEAC, 1981; pp.86-91. 
epitáfio da velha convicção antissistêmica a respeito do papel dirigente da classe operária, que aliás nas jornadas de maio foi a última a entrar e a primeira a sair, só que vitoriosa com os acordos de Grennelle. Tampouco vou arriscar qualquer palpite sobre as novas classes que estariam entrando no cenário naquele momento, basta-me a constatação de que ao lado do mundo do trabalho que se pusera em marcha contra o compromisso fordista, vieram se alinhar, não sem conflito quanto à escala das prioridades, os assim chamados desde então Novos Movimentos Sociais, constituindo um novo front responsável por uma outra agenda antissistêmica de inédito caráter "pós-materialista", como logo foi batizada. Desse mesmo front, que deixara para trás as virtudes burguesas clássicas do produtivismo e da performance individual máxima, também fazia parte uma Grande Recusa no chão de fábrica: insubordinação, sabotagens, sequestros, tudo contra as cadências infernais e todo o conjunto de disciplinas que caracterizam a prepotência do capital. Nela ecoavam, vindas do lado de fora, as mobilizações em torno dos valores, por assim dizer, pós-aquisitivos: realização pessoal, solidariedade, etc.

Na boa observação de André Gorz, a explosão de maio, cujos estilhaços continuariam se espalhando ao longo de toda a década recalcitrante de 70 , provara, ao contrário do que apregoavam os teóricos do aburguesamento das classes não proprietárias, que as proteções e prestações do Estado Providência não haviam reconciliado as populações com a ordem capitalista, pelo contrário. Mas também (confirmando o diagnóstico neoconservador acerca das raízes culturais da ingovernabilidade, acrescento), ao se alastrar por todas as instituições que não apenas as do miolo produtivo básico - das escolas aos hospitais, das prisões à mídia, dos órgãos de Estado ao meio ambiente - demonstrara que fora posto em questão o fundamento de todo o edifício, ou seja, o próprio mecanismo de reprodução simbólica da sociedade. ${ }^{41}$ Estava aberta assim uma brecha na sociedade salarial, de sorte que o conflito estaria por toda a parte e sua radicalização se daria no terreno cultural, além do mais foco de contaminação do mundo heterônomo do trabalho - ainda na observação do mesmo Gorz, mas agora na condição de ideólogo da nova sociedade da cultura, em construção desde então, sobre os escombros da extinta sociedade do trabalho ${ }^{42}$.

Desnecessário relembrar que a chamada volta à cidade daqueles anos de rescaldo meia oito (e não só na Europa, mas sobretudo lá e particularmente na França e na Itália) forneceu o cenário mais visível desse primeiro turno cultural. Por uma breve temporada pareceu possível emperrar a máquina urbana de crescimento, contrapondo ao núcleo duro produtivista do sistema a cidade como valor de uso. Tudo se passava então como se o novo souci de l'urbain tivesse renascido à sombra do ímpeto pós-material que vazara pela brecha de 68 (sintoma ainda não se sabia bem do quê). Nada mais antivalor (de troca) do que o "lugar" redescoberto e contraposto ao espaço homogêneo dos modernos e do mercado. Portanto, muito melhor reabilitar do que demolir; intervenção, só em migalhas; reativar a memória porém evitando o assassinato museográfico dos sítios históricos; valorizar o contexto, o habitat ordinário, reanimar a vida dos bairros, sem violentar os moradores, e por aí a fora, como hão de recordar pelo

41. Cf. André Gorz, Misères du présent, richesse du possible, Paris: Galillée, 1997; pp.23-25.

42. Cf. Ibidem; pp.74-131. 
menos os veteranos que ainda têm notícia daquela geração - a segunda? — de índole oposicionista.

Visto de hoje, talvez o mais surpreendente naquela fase é que ninguém falava em cultura! Não passava pela cabeça de nenhum protagonista daquela geração urbanística estar engajado numa ação cultural... Retrospectivamente se dirá que os paradigmas já não eram os mesmos, porém ainda não se cogitara dualizar tanto a teoria quanto a prática, justapondo "gramáticas das formas de vida", enquanto reprodução cultural, aos conflitos distributivos da esfera econômica, para não falar na absorção da segunda pela primeira à título de contraprova da culturalização em marcha de toda a realidade social. Mas logo se começaria a dizer que era isso mesmo que estava ocorrendo.

Dito isso, seria preciso acrescentar que essa mesma geração, que os neoconservadores não hesitariam em incluir entre os protagonistas de uma cultura hostil, e que chegavam até a corporificar numa nova classe, produtora e monopolizadora do "sentido" (que logo adiante se transmudarão em intermediários culturais provedores de identidade e estilo, mas quando então a cultura fazia tempo deixara de hostilizar o que quer que seja), vivia em regime de condomínio com uma nova configuração da máquina urbana de crescimento, à qual se estava adicionando ingredientes novos. Estou me referindo à invenção do cultural ${ }^{43}$ (agora de caso pensado) por um star system arquitetônico, associado a governantes movidos pela mosca azul da monumentalidade espetacular, capaz de

43. Estudei um caso exemplar deste dispositivo em "Os dois lados da Arquitetura Francesa Pós-Beaubourg", publicado originalmente em 1988 na revista Novos Estudos e recolhido no volume O lugar da Arquitetura depois dos Modernos, EDUSP $(1993,95,2000,2015)$. Voltarei de forma breve ao tema no próximo tópico. produzir, através de uma política de coalizões, os consensos indispensáveis. Mas não um cultural qualquer, aqui o tourning point que está nos interessando demarcar, um cultural - da indústria da consciência às grandes fachadas, passando pelas gentrificações pertinentes - paradoxalmente (ou não?) respaldado pela aura libertária da resistência antiprodutivista cuja gênese acabamos de recordar, que assim voltava a se legitimar uma segunda vez, redescobrindo-se plenamente "cultural" desde sempre. Nada a ver portanto com o que se entendia por cultura no ciclo histórico anterior, o breve interregno da Era do Crescimento do segundo pós-guerra, para não falar é claro naquela velha esfera autônoma e transcendente da extinta Idade Liberal-burguesa. Tudo a ver, portanto, com o mito bifronte da cidade-colagem-grande-projeto que então nascia, e da qual a Paris de Mitterand será o exemplo máximo e seguramente o ponto de inflexão.

Deu-se assim uma metamorfose do "cultural", cujo pós-materialismo, a princípio reativo, foi se tornando pró-ativo, para não dizer cooperativo, à medida que se estetizava e se concentrava nos valores expressivos de uma ordem social que alegava a seu favor haver destronado o primado das relações de produção em nome das relações de "sedução", como foi saudada a Era do Vazio que se iniciava $^{44}$ (talvez ajude referir-se então a um segundo turno do cultural turn, de que falei na abertura deste ensaio). Se estou certa, nem foi preciso esperar pelas grandes desregulações do período seguinte, a começar pela flexibilização da rigidez fordista, para apressar a mutação indolor do libertário-cultural, empenhado na recuperação da riqueza simbólica das formas urbanas (na formulação de

44. Gilles Lipovetsky, L’ère du Vide, Paris: Gallimard, 1983. 
Leon Krier), no embrião dos futuros semeadores de iscas culturais para o capital - para os quais a monotonia funcional do Modernismo com certeza criara uma forte demanda reprimida ${ }^{45}$.

Convenhamos, pensando na promoção suave da terceira geração urbanística pela escada rolante do cultural turn: o mundo arranjou-se de tal modo que já não é mais necessário deixar de sentir-se à esquerda, pelo contrário, tal sentimento sai reforçado, para sustentar uma opinião tão sob medida quanto a ideia politicamente correta de que a Cultura finalmente desceu de seu pedestal elitista, bem como de seu confinamento populista, expandindo-se e infiltrando-se por todos os domínios relevantes nas arenas econômica, social e política, reconstituindo-as segundo as regras de novos "formatos culturais", utilizados por sua vez como recursos de valorização nos respectivos âmbitos $^{\mathbf{4 6}}$. Com o sinal trocado, era justamente isso que Guy Debord queria dizer quando profeticamente anunciou que a cultura seria a "mercadoria vedete" na próxima rodada do capitalismo, exercendo a mesma função estraté-

45. A observação é de David Harvey, que de passagem associa os movimentos culturais dos anos 60, expressão parcial daquele desejo recalcado de "riqueza simbólica”, à expansão do mercado de estilos, op cit..; p.82. A mesma linha evolutiva adquire nitidez máxima se acompanharmos a curva descrita pelo pós-estruturalismo francês, cujo repúdio do "espelho da produção" (Baudrillard), no qual se refletiriam todas as "disciplinas" modernas, culmina numa certa estilística da existência, como no último Foucault, o qual por assim dizer abriu a porteira para a epidemia "ética" nos meios outrora contestatários. Os quais, aliás, foram deixando de sê-lo também por falta de adversários - outro pivô na guinada pró-sistêmica dos agentes da inovação cultural. É que uma vez extinta a velha classe dominante burguesa, responsável em razoável medida pela persistência do antigo regime cultural (sem falar nos usos e costumes), os novos donos da riqueza e do poder foram se tornando, na sua degradação, indiscerníveis da personalidade hedonista, sobretudo em seu horror à frustração: a bem conhecida subjetividade narcisista liberada pela reviravolta cultural de que estamos falando.

46. No resumo de John Kraniauskas, op cit.; p.16. gica desempenhada nos dois ciclos anteriores pela estrada de ferro e pelo automóvel ${ }^{47}$. A seu ver, a alienação humana chegaria então ao seu grau máximo.

Em resumo, a partir da desorganização da sociedade administrada do ciclo histórico anterior, cultura e economia parecem estar correndo um na direção do outro, dando a impressão de que a nova centralidade da cultura é econômica e a velha centralidade da economia tornou-se cultural, sendo o capitalismo uma forma cultural entre outras rivais. O que faz com que convirjam: participação ativa das cidades nas redes globais via competitividade econômica, obedecendo portanto a todos os requisitos de uma empresa gerida de acordo com os princípios da eficiência máxima, e prestação de serviços capaz de devolver aos seus moradores algo como uma sensação de cidadania, sabiamente induzida através de atividades culturais que lhes estimulem a criatividade, lhes aumentem a autoestima, ou os capacitem do ponto de vista técnico e científico. Tais iniciativas, sejam elas grandes investimentos em equipamentos culturais, ou preservação e restauração de algo que é alçado ao status de patrimônio, constituem pois uma dimensão associada à primeira, na condição de isca ou imagem publicitária.

O que estou tentando mostrar é que hoje em dia a cultura não é o outro ou mesmo a contrapartida, o instrumento neutro de práticas mercadológicas, mas ela hoje é parte decisiva do mundo dos negócios e o é como grande negócio. A tal ponto que se torna mais ou menos indiferente se se trata de um grande museu - tome-se a título de exemplo, as investidas de Thomas Krens, executivo da fundação Guggenheim, para criar uma filial do $\mathrm{Mu}-$

47. La Societé du Spetacle, Paris: Gallimard, 1992; \#191. 
seu na América do Sul — ou de uma montadora (veja-se a semelhança dos argumentos e das condições impostas por Krens) - tanto quanto tantas outras iniciativas, por exemplo, neste ano de 2000, propiciadas pelo evento "200 anos" (de Revolução Francesa), ou “500 anos" (de Descobrimento da América e, agora, do Brasil).

\section{Variações em torno de um mesmo modelo}

\section{Paris}

Retomando o fio, gostaria de recuar um pouco no tempo para relembrar que não são de hoje os argumentos que venho contrapondo ao Planejamento Estratégico, por certo avant la lettre e nos meus próprios termos, ao analisar, como referi há pouco, os dois lados da arquitetura francesa pós-Beaubourg, não por acaso, dois lados complementares: os chamados Grandes Projetos (do novo Museu que abrigaria os Impressionistas, na Gare d'Orsay, à ampliação do Louvre, ou à Nova Biblioteca Nacional, sem esquecer o monumental Arco de La Défense) e o retorno contextulista à cidade. ${ }^{48}$ Os primeiros, via de regra, construções monumentais de iniciativa do governo central, e consistindo, em geral, em equipamentos culturais - esta, a grande novidade, como logo veremos. E Grande Projetos destinados, entre outras coisas, a catalisar a recuperação do entorno, enfim, edifícios emblemáticos, como se diria no jargão de hoje (o imenso Arco de Spreckelsen, por exemplo, não tinha outra função senão criar um "core” artificial para La Défense,

48. Remeto o leitor ao meu texto citado há pouco: "Os dois lados da arquitetura francesa pós-Beaubourg”. dando ares de urbanidade ao gélido novo centro das altas finanças).

É claro que a renovação de Paris não resultou de um Plano Estratégico propriamente dito, previamente estabelecido, mas, qualquer que seja a denominação adotada, para o princípio mais do que duvidoso - para dizer o menos - de se "fazer cidade" (seja dito novamente em jargão) mediante show-cases, não seria muito difícil reconhecer naquela renovação espetacular, o modelo dos atuais mega-empreendimentos-âncora, os motores da "requalificação" urbana. ${ }^{49}$ Estava tudo lá, naquelas providências de regulação flexível do urbano, da ampliação da indústria cultural que incorporava a cultura dos museus e suas adjacências highbrow ao capitalismo de imagens, da nobilitação arquitetônica do mundo dos negócios à correspondente mitologia urbanizadora do terciário avançado, sem a qual não se pode aspirar ao status de cidade global.

Assim sendo, se é possível sustentar sem erro que a matriz da concepção da cidade como máquina empresarial de crescimento é americana, à qual foi se incorporando massivamente estratégias de nítido corte cultural, pode-se acrescentar com igual segurança que essa conjunção de empreendimento urbano e investimentos culturais de porte industrial data da generalização daquela invenção francesa, da qual, o Beaubourg é a raiz projetual. E se o que se disse quanto à linha evolutiva do cultural turn está cer-

49. Cf. Nuno Portas: em um artigo publicado na Itália - "L'emergenza del projetto urbano"(em Revista Urbanística 110, Roma, giugno 1998) - associa os projetos de "terceira geração" ao seu caráter mediático, ou seja à preferência por Grandes Projetos, cuja visibilidade seria necessária à competitividade, além de, por seu poder de impacto, facilitarem o "consenso e o compromisso dos atores". Não que ele reduza esta urbanística a megaprojetos, mas, como um dos protagonistas desse novo planejamento, reconhece o papel estratégico de tais iniciativas. 
to, o efeito Beaubourg terá sido tanto mais bem sucedido por trazer na fachada, além da evocação bem calculada da voga da arquitetura megaestrutural de ostensiva sugestão utópica, as marcas das rebeliões da década anterior. $\mathrm{Na}$ verdade, embora toda aquela quermesse comandada pela arquitetura, a que iremos assistir desde então, tivesse sido inaugurada com a "animação cultural" programada em grande escala pelo brinquedo de armar chamado Beaubourg, é só dez anos mais tarde que se consolida, com toda a pompa e ostentação, a colonização urbano-cultural pelo reino da mercadoria - numa dimensão jamais vista e num registro despudoradamente midiático, justamente a marca de todo o ambicioso projeto arquitetônico-urbanístico que se preze nesta passagem de século. $\mathrm{O}$ novo marco deslocara-se assim para o museu-espetáculo de Orsay, ou para a inusitada pirâmide de vidro do Louvre. E a contraprova de que o mesmo show continua a ser relançado a cada nova temporada pode ser encontrada na recente reestruturação milionária do Beaubourg.

Como disse, aqui a grande inovação, se é que se pode falar assim, a saber, a invenção pela esquerda francesa, no poder desde 1981, da máquina cultural de crescimento. Ou seja, a substituição escandalosa - nos dois sentidos da palavra - do Estado Social pelo Estado Empresário-Cultural, cujo sucesso crescente ainda por cima se alimentava explicitamente da corrosão programada do primeiro. Tudo em nome de uma ultrapassagem moderna de uma sociedade até então protegida para uma sociedade de risco: a esquerda enfim se abria para a "complexidade", na fraseologia bem conhecida por aqui não faz muito tempo. É claro que a direita sorria diante das declarações oficiais de que doravante cultura e economia constituiriam um mesmo combate ${ }^{50}$, que ninguém mais a superaria, ela, a esquerda, em matéria de modernismo e realismo, que ficara para trás o preconceito estatista da velha esquerda de uma vez por todas era preciso entender que cultura não se faz sem dinheiro e ponto. Sorria porque o script era seu, como vimos, e não poderia imaginar que, na primeira virada política da conjuntura de crise dos anos 70 , a esquerda tomaria ao pé da letra seu diagnóstico deslavadamente ideológico quanto às origens culturais dos bloqueios aos quais atribuíra a responsabilidade pela lucratividade em queda. Para se ter uma ideia do disparate daquela "descoberta" da prioridade cultural, bastaria lembrar que até mesmo o ainda hoje incipiente mecenato empresarial foi induzido pelo Estado no recalcitrante patronato francês, que obviamente também comprou com lucro outra novidade de esquerda, a saber que o patrocínio cultural seria a expressão natural e legítima de um impulso ético-convivial na base de todo o empreendimento econômico consistente. Coube assim à esquerda no poder a demonstração do teorema conservador acerca da centralidade da cultura na gestão das populações precarizadas pela guerra econômica. À essa expansão do ethos privatista até os confins da motivação estética, atribuiu-se o condão providencial de um efeito de choque na luta contra a crise. Efeito próprio à forma-publicitária a que chegara então não só a nova monumentalidade arquitetônica, como também a Paris gentrificada, como que por um passe de mágica cultural. Espetáculo por espetáculo, também não surpreende que nesta Era Mitterrand de glamourização do economicismo

50. Nas palavras do Ministro da Cultura Jack Lang: "a cultura é o nosso petróleo". Cf. a respeito os livros de Jacques Renard, L'élan culturel, Paris: Puf, 1987 e Jacques Rigaud, Libre Culture, Paris: Gallimard, 1990. 
de esquerda, a indústria cultural tenha sido revista como a fronteira dos processos industriais do futuro, com a cidade-empresa como principal item.

\section{Barcelona}

No outro lado dos Pirineus, numa região em permanente guerra de auto-afirmação, novamente a esquerda, agora diretamente na gestão de uma das cidades mais importantes da Europa, se lançava, de caso pensado e sem esconder suas motivações, numa aventura semelhante. A fórmula era importada, mas já incorporando a lição que chegara através do Atlântico: a cidade-empreendimento de formato americano. Estou me referindo à Barcelona e ao seu modelo de planejamento, exportado hoje para o mundo todo e muito especialmente para América Latina - o que nos obriga a expô-lo com algum detalhe mesmo que seja uma variante a mais (preservadas algumas particularidades, como veremos) da cidade-empresa-cultural. ${ }^{51} \mathrm{E}$ o fizeram com uma tal perícia, que conseguiram passar a impressão que tudo começou com Barcelona. De fato, insisto, não foi. ${ }^{52}$ De qualquer modo, a capital da

51. Um exemplo, do interesse despertado pelo Planejamento Estratégico, aqui mesmo, no Brasil, foi a série de textos imediatamente publicados, em geral apologéticos. Por exemplo: a coletânea de Tânia Fischer, Gestão Contemporânea, cidades estratégicas e organizações locais, Rio de Janeiro, Fundação Getúlio Vargas, 1996; Sarah Feldman e Jorge Kayano (orgs.), Avaliação de experiências de Planejamento Estratégico de cidades, São Paulo: Polis, julho de 1988 (xerox); Rodrigo Lopes, Cidade intencional: o Planejamento Estratégico de cidades, Rio de Janeiro: Mauad, 1998; Ricardo Lima e Fernando Rezende (orgs.), Rio-São Paulo, cidades mundiais, Rio de Janeiro: IPEA 1999; o futuro já chegou - eixo Tamanduathey, publicado pela Prefeitura de Sto. André; e O município no século XXI, cenários e perspectivas, publicado pelo governo do Estado de São Paulo, CEPAM, 1999.

52. Aliás, é bom lembrar, com a assessoria direta do próprio prefeito que inventou a fórmula, James Rouse - referido por nós aqui - e de sua empresa, com quem os catalães mantinham intercâmbio desde a gestão Bohigas.
Catalunha inaugurou - a partir do momento em que alguns arquitetos catalães formularam o "plans cap al 92", posteriormente "Barcelona 2000" - uma urbanística que passou a ser identificada justamente como a matriz do Planejamento Estratégico. Desnecessário dizer que nem mesmo este foi uma invenção ibérica, pelo contrário, a técnica adotada numa planificação urbana que se autodenomina estratégica é, como já vimos, americana: inspiradas nas empresas privadas, nos anos 60, cidades e regiões passaram a proclamar que a máquina de morar/trabalhar/etc. moderna não mais atendia às exigências de uma nova fase de reestruturação do capitalismo, inventando, em nome de um novo e acintoso conceito de performance urbana, máquinas urbanas de produzir renda (para voltar ao conceito de Molotch). Aliás o mote já era adotado por algumas administrações municipais na própria Europa, como Birmingham ou Rotterdam, sem falar no novo plano para Madri. Mas com o tempo o planejamento de Barcelona foi se convertendo num paradigma dentro disso que estamos chamando de urbanismo de "terceira geração", e possivelmente porque de alguma maneira soube renovar a fórmula, que aliás contava com um ingrediente indispensável e muito bem explorado: o marketing que as Olimpíadas de 92 propiciaram.

Sem dúvida, o grande aporte do Governo Central devido às Olimpíadas, mais os investimentos privados motivados pelo evento, favoreceram um projeto de uma abrangência inusitada, numa escala incomparável com a feira de Baltimore de 20 anos antes. Mas havia também, não há como negar, uma experiência acumulada de gestão urbana de esquerda, em Barcelona, que fazia com que, mesmo quando o princípio que a norteava fosse o das intervenções pontuais, se destinasse a recuperar o conjunto 
da cidade - não havia, ao menos de forma explícita, a intenção de beneficiar uma elite local, criando nichos de alto valor imobiliário. Portanto, insisto: não há de ser sem motivo que Barcelona se tornou a grande referência — só um êxito razoável do modelo, não apenas marketing, poderia explicar tão rápida difusão mundo afora, e justamente na versão dos urbanistas catalães. Aliás, discípulos e colaboradores de um dos grandes artífices da segunda geração: Oriol Bohigas, o qual, à frente da Secretaria do Planejamento - rebatizada por ele de Projeto Urbano - radicalizara a proposta de modestas intervenções pontuais, com um projeto por sinal bastante ambicioso, de construção de cem praças (não por acaso numa fase de franca expansão da ideologia do lugar público, além do mais numa cidade onde as pessoas conservavam o hábito do encontro em espaços dessa natureza), no intuito de, por difusão, ou através de uma "metástase benigna" (expressão que depois se banalizou), provocar uma reurbanização geral.

Não demorou muito contudo, para que uma tal política, centrada na ideologia da diferença (Campos Venuti falaria em urbanismo rarefeito), revelasse sua fragilidade, reforçando a fragmentação urbana; de sorte que, visando debelar as novas patologias da cidade foi-se cristalizando um novo ciclo de gestão urbana. Ora, as Olimpíadas eram um bom pretexto para uma correção de rumo e, certamente propiciada por ela, uma nova direção acabou sendo dada à Secretaria, então sob a direção de Bousquets ${ }^{53}$, quando voltou à denominação antiga, de Planejamento, mas agora obedecendo a uma nova fórmula que procurava conjugar microintervenções a um plano mais geral. As

53. Parte dessas informações me foram fornecidas pelo próprio Bousquets em janeiro de 1991. novas estratégias viriam tornar isso mais efetivo: infra-estrutura, sistema viário, restaurações, residências (as vilas olímpicas), redes hoteleiras, novos equipamentos esportivos, sem falar na valorização do seu bem natural maior, a face para o mar - calçadões na zona portuária, praias, etc. E o mais importante, o reforço dos valores mais representativos de Barcelona, por exemplo, no campo das artes, Miró, Picasso, Tapiés; do urbanismo e da arquitetura, Cerdá, Gaudí, o Modernismo catalão, "regionalismos críticos" pós-modernos, etc.

O processo, portanto, que se iniciou em 1980, ainda sob a égide do design urbano, acabou ganhando, especialmente a partir da formulação do plano "Barcelona 2000", uma dimensão maior, em todos os sentidos (generalizavam-se as intervenções e a sua escala): tratava-se de estabelecer uma meta clara, que evidentemente não se esgotasse no evento de 1992 e que dissesse respeito ao que se aspirava com todas estas melhorias para a cidade como centro vital, na região e na Europa; em suma, definir o lugar de Barcelona como metrópole europeia, encontrar o "seu nicho estratégico", tornando-a internacionalmente competitiva - nas palavras de Roig i Marti (Diretor da Promoção Econômica de Barcelona, em 90), que acrescentava, citando Boisot: "a planificação urbana é um jogo contra a natureza, a planificação estratégica é um jogo contra adversários". ${ }^{54}$ Para tanto, advertia na ocasião um outro

54. As citações que seguem, dos membros do Conselho do Plano Barcelona 2000, ver La ciudad ante el 2000, Ayuntament de Barcelona, 1990. Ainda sobre Barcelona, a bibliografia publicada pelo Ajuntamentde Barcelona e que foi consultada: Barcelona. Una nueva estructura social, 1988; Barcelona, Metrópolis Meditarrània, 1988; Barcelona, Espais Urbans, 1981-1991; Estudi de l'Eixemple, 1983-1988; Urbanisme a Barcelona, Plans cap al 92, 1988 (2 $2^{\mathrm{a}}$ ed.); Barcelona espacio publico, 1993; Barcelona, arquitectura y ciudad 1980-1992, Barcelona: GG, 1990. 
membro do Conselho, o geógrafo Oriol Nel-lo, era necessário apostar fortemente na autopromoção publicitária, ou seja, como já estava ocorrendo com muitas outras cidades (dizia ele), explorar e potencializar aquelas características pelas quais a cidade é prontamente identificada, aquilo que constitui a imagem-Barcelona. Na receita, um pouco de tudo: das gentrificações de praxe às exortações cívicas, endereçadas, como lembrado antes, aos chamados atores urbanos, que de recalcitrantes se tornariam cada vez mais cooperativos em torno dos objetivos comuns de city marketing (o que aliás, diga-se de passagem, não era algo desprezível, numa região em estado de mobilização permanente por afirmação de identidade, aliás de nítido teor separatista). Sem maiores rodeios: desenvolver uma imagem forte e positiva da cidade, explorando ao máximo o seu capital simbólico, de forma a reconquistar sua inserção privilegiada nos circuitos culturais internacionais.

Daí a necessidade de se espelhar no exemplo de Paris, canalizando investimentos maciços para a área da cultura: por exemplo, a reconstrução do Pavilhão de Mies van der Rohe, em Montjuic; neste mesmo local, a renovação do Museu de Cultura da Catalunha por Gae Aulenti (a mesma arquiteta que transformara a Gare d'Orsay no museu pós-moderno mais bem sucedido até àquela data), a ampliação do Museu Miró que ao mesmo tempo é um monumento arquitetônico de G. Sert, sem falar nos estádios e centros esportivos olímpicos, representando o star system da arquitetura internacional - Gregotti, Bofil e Isosaki; some-se a isso o inusitado Museu de Arte Moderna, do arquiteto Richard Meyer, em pleno Bairro Antigo, onde se concentram vários edifícios históricos e onde foram restaurados e adaptados alguns como o Centro de Arte Santa Monica, a sede da Secretaria de Cultura na Casa de Caritat, e o Museu Picasso; do outro lado da Rambla, o novo Teatro Nacional, novamente do criador catalão de ícones pós-modernos, Ricardo Bofil, que também projetou o novo aeroporto; mais, resultado de requalificações ou ampliações: a Fundação Tapiés, o Palácio da Música, o Museu da Ciência. E, tudo isso, de modo a dar realce às próprias tradições locais: em grande parte, como enfatizavam os seus formuladores, vinculadas à sua própria arquitetura — dos desenhos urbanos originais (os quarteirões de Cerdá ou a cidade moderna do Plano Maciá), às suas casas modernistas do Bairro de La Gracia, dentre elas, em especial as de Gaudí (tudo passado devidamente a limpo, sem esquecer de "completar" a Igreja Sagrada Família), além da arquitetura catalã contemporânea, posta em desfile nos novos projetos, em grande número (especialmente de design urbano e Vilas Olímpicas) de seus próprios arquitetos.

Obviamente, o que se estava a construir era, nada mais nada menos, do que a imagem prestigiosa da cidade, voltada sobretudo para o exterior em função da competitividade sistêmica na qual Barcelona se lançava - o que a obrigava a satisfazer a qualquer custo as novas exigências do capitalismo de imagens, do desenvolvimento do terciário avançado à uma arquitetura up to date, a ponto de incluir toda uma série de edificações que seguissem o padrão das novas centralidades empresariais das megacidades. Quanto mais peças no mostruário melhor, porque afinal o que estava na vitrine era a própria capital da $\mathrm{Ca}-$ talunha, e aí não há de ter pesado pouco a convergência local entre tradição e ultramodernidade. Aliás, talvez o interesse maior, e o relativo sucesso deste modelo-Barcelona, decorra dessa situação limite: de um certo modo, ter podido combinar regionalismo e neo ou ultramodernismo, teoria do "lugar" e planejamento estratégico, uma 
fórmula por assim dizer híbrida de urbanismo de segunda e de terceira geração, ou ainda de gestão urbana de molde empresarial americano e previdenciário-cultural (se é possível falar assim) europeu, notadamente francês. E isto não só por opção de seus arquitetos-urbanistas, mas seguramente por se estar vivendo um período de transição, ou ao menos, de relativa indefinição, tanto quanto ao futuro de Barcelona, como da Espanha na União Europeia.

Mas é preciso também não esquecer o outro lado da equação, que, aliás, de acordo com seus promotores, constitui a originalidade do modelo: a mobilização da opinião pública. Como lembrava à época um dos coordenadores do plano 2000 - Juan Campreciós -, tais empreendimentos visam igualmente incrementar a adesão ao ícone da cidade e a "auto-estima dos cidadãos", motivando-os a participar, através de um consentimento "concertado", na elaboração e execução do plano. Esta, nas palavras de Jordi Borja, a "marca" Barcelona: trata-se - dizia ele de "uma articulação entre atores públicos e privados para promover estratégias concertadas de desenvolvimento e sua organização para uma ação conjunta". O que significa uma ampla participação das instituições e mesmo da população, partindo - acreditava o presidente do Conselho - "de diálogo sincero e de vontade de consenso" (!) Ora, o empenho dos indivíduos, ao que parece promovidos ao grau de cidadãos, teria como poder catalisador a afirmação da identidade político-cultural (novamente Borja...) - e assim por diante, de ambiguidade a mal-entendido entre política real e epiderme cultural.

Tema retomado com ênfase na proposta de generalização dessa experiência, apresentada, anos mais tarde, no Habitat de Istambul (como já demos notícia aqui mesmo), onde foi apontado como componente essencial às no- vas plataformas urbanas, o empenho dos "agentes" que podem promovê-la, ou ainda, o que é mais importante, a mobilização de todos os recursos capazes de despertar nos indivíduos "um patriotismo de cidade" e concomitante "desejo de inserção" (nas redes globais, obviamente). Por isso mesmo, Borja e Castells, no texto a que estou me reportando, preparado para a ocasião, definem a cidade como sendo basicamente um "espaço simbiótico (poder político-sociedade civil) e simbólico (que integra culturalmente, dá identidade coletiva a seus habitantes e tem um valor de marca e de dinâmica com relação ao exterior)". A combinação de "cultura cívica" e "consenso público" ou, ainda na mesma linha do eufemismo, "vontade conjunta", formariam a argamassa dessa construção de cidade, permitindo-lhe dar "um salto adiante, tanto do ponto de vista físico como econômico, social e cultural" ${ }^{55} \mathrm{Na}$ verdade, como observei páginas atrás, nada com que os responsáveis pela cidade-máquina de crescimento já não tivessem atinado, a diferença é que onde os teóricos (apologistas ou críticos) da cidade-empresa viam uma convergência rentável, estes últimos ideólogos pretendiam que fosse uma "articulação" concertada..., e portanto capaz de induzir uma nova onda de civilidade. Há, contudo, quem pretenda que não foi bem assim, lembrando a pequena participação da população junto ao conselho gestor do plano, tanto quanto a quase inexistência de moradias para pessoas de baixa renda enquanto existia um estoque ocioso nas Vilas Olímpicas, ou ainda, que a requalificação-gentrification do bairro antigo que passou a abrigar o moderníssimo

55. Manuel Castells e Jordi Borja Local y Global cit. Esta plataforma, apresentada no Habitat, é bastante esmiuçada no ensaio de Carlos Vainer publicado neste mesmo livro: "Pátria, Empresa e Mercadoria..." 
MAM convivia muito bem com a periferização crescente da cidade, algo novo no cenário de Barcelona, sem falar no fim de boa parte das parcerias, motivadas exclusivamente pelo marketing das Olimpíadas, quando também parte da euforia mobiliziatória teria se esgotado, etc.

De qualquer modo, uma situação por vários motivos "singular". No intuito de resguardar pelo menos as intenções dos que a promoveram, admitamos que se trata de um outro caso de protagonistas vitimados por mais uma ironia objetiva. A verdade é que, ao se concretizar e generalizar, o modelo acabou por desvendar sua base real, ainda um tanto nebulosa: as cidades, transformadas em novos "atores sociais complexos" - como dizem ${ }^{\mathbf{5 6}}$ —, não passam de balcões de negócios..., a disputar a nuvem financeira e as hordas de turistas que circulam pelo mundo. Legitimados sem dúvida pelo consentimento da parcela da população para a qual a participação nos novos negócios não é nada desprezível. Além do mais o receituário que talvez não pudesse ser aplicado ao pé da letra em sua cidade de origem, pois encontrara - para bem e para mal - um processo já a meio caminho, virou desde então bula papal para as cidades que tentam ou são induzidas a imitar Barcelona. ${ }^{57}$ Os exemplos estão aí e são conhecidos de todos nós.

Além disso, o êxito, pelo menos no plano mais visível da empreitada, em grande parte mobilizada pela Olimpíada, logo tornaria os Grandes Eventos mais um ingrediente indispensável da nova fórmula. Vem daí, é claro, as cam-

56. Em La ciudad ante el 2000, cit.

57. Um dado nada desprezível (que me foi fornecido por Carlos Vainer): o BIRD está exigindo das nossas cidades "planos estratégicos" para conceder financiamento. panhas oficiais para sediarem alguma Olimpíada ou Copa do Mundo - estimulados pelos novos "personal trainers" ou "managers", em outros tempos urbanistas-, das administrações dos países ditos emergentes, ansiosas por participarem da nova ordem global .

Aliás, um parêntesis final, sobre a retomada dessa mesma receita na própria Barcelona pós-Olímpica. Quando a festa acabou, muitos projetos tinham ficado a meio caminho, as dívidas eram imensas, a ressaca maior ainda. Inventou-se então um novo evento âncora, o "Fórum das Culturas", para ocorrer em 2004. Assim, a capital do urbanismo mais em vista, ao menos da Europa, e fartamente exportado (especialmente para os países sem tradição na área - como o nosso), trouxe novamente para o centro das discussões tanto a questão da cidade-ocasional ou cidade-acontecimento (na expressão de Indovina que citávamos há pouco, retomada por Bohigas para defender ainda uma vez os surtos de desenvolvimento motivados por grandes eventos, como ocorrera, segundo ele, com Barcelona ao longo de sua história - a famosa Exposição Universal de 1888, ou a de 1929, e, finalmente, a Olimpíada de 92), quanto o próprio modelo adotado por ela no último quarto de século. Não por acaso, a própria Cultura virá a ser a grande protagonista de mais um evento responsável pela reabilitação, novamente, de uma extensa área urbana.

Assim, o projeto de "Barcelona 2004" surge para relançar a cidade num novo surto empreendedor, embora os atores comecem a mudar - a era Maragall/Bohigas/Busquets se encerrara com o início da gestão de Juan Acebillo (1999). No entanto, se os promotores daquele primeiro surto "regenerador" não se reconhecem nos desdobramentos posteriores, foram eles que lançaram as coordenadas de um urbanismo cada vez mais dominado pelos agentes 
privados e seu ponto de vista sobre a cidade como grande negócio, apesar das reiteradas alegações de espaço democrático em construção. Voltamos ao ponto nevrálgico de um antigo argumento, a saber, a convergência de fundo entre duas tendências que se pretendiam contrapostas: a dos contextualistas e dos empreendedores - convergência objetiva que se expressa na cidade-empresa-cultural, da qual Barcelona 2004, com o seu Fórum das Culturas, será o arremate. Ou seja, Barcelona (com as ressalvas que se possa fazer) dava continuidade ao seu projeto de cidade global, mas numa versão aggiornata do Planejamento Estratégico. ${ }^{58}$

\section{Bilbao}

Um outro exemplo que também está fazendo escola, ainda um caso espanhol, igualmente de muita visibilidade. Desta vez Bilbao ${ }^{59}$, uma cidade degradada por uma década de desindustrialização, perto portanto do ponto ótimo da "sensação de crise". Um Plano Estratégico foi elaborado, mas parecia patinar, quando o diretor da Fundação Guggenheim convenceu o prefeito da cidade a construir um edifício que pudesse identificar a capital basca como, por exemplo, Sidney, pelo edifício do seu teatro de Ópera - o resultado é bem conhecido, um museu projetado pelo arquiteto americano Frank Gehry, uma

58. Todo o desdobramento deste projeto - de 2000 a 2011, é analisado no meu ensaio "Barcelona revisitada", em: Berlim, Barcelona, duas imagens estratégicas, cit.

59. Sobre estes exemplos, ver "Vendo Cidades", de 1998, cit. Cf. também, de um ponto de vista apologético, um dos urbanistas responsáveis pelo Plano Estratégico de Bilbao: Eduardo Leira, "Il piano de una nuova cittá lineare per Bilbao: La construzione della metropoli. Un Progetto Strategico", in Casabella $\mathrm{n}^{\circ} 622,1998$. extravagante flor metálica de 200 milhões de dólares (entre construção, franquia e acervo), mais de $30.000 \mathrm{~m} 2,70$ m. de altura, a emergir do rio Nérvio, destinado a exponenciar a oferta cultural da cidade, como se diz na língua franca do momento. Quanto à reversão do processo de deterioração da cidade são outros quinhentos, que ainda estão para ser avaliados. Proclamam os seus promotores que a área à volta está sendo "requalificada" — ou seja, como não poderia deixar de ser, está se valorizando (business as usual). De qualquer modo já se sabe que, se o afluxo de turistas tem superado as expectativas, segundo as estatísticas visitam a cidade apenas $5 \%$ dos que foram atraídos por aquele objeto estranho que, casualmente, é um Museu, sem contar que a extravagância também é efêmera.

Gostaria de destacar ainda outro aspecto dessa negociação de que resultará a nova imagem da cidade. O que esta última anuncia? Em primeiro lugar, que a cidade tem um Gehry, assim como São Francisco tem um museu assinado por Mario Botta, Los Angeles, um Isosaki, mais um Richard Meyer, etc., como aliás também Barcelona ou Frankfurt - todos membros do estrelato da arquitetura mundial, numa verdadeira ciranda de museus e arquitetos, onde os exemplos europeus, depois de arremedarem a fórmula americana, retornam aos Estados Unidos e assim por diante (Gehry além de ter o seu projeto do Disney Hall de Los Angeles desengavetado, assina pelo menos mais outros quatro museus americanos: um, em Biloxi, Mississipi, outro, no Tennessee, a ampliação da Galeria Corcoran, em Washington, e o novo Guggenheim de NY - afinal a ampliação que havia sido construída há poucos anos era arquitetonicamente inexpressiva, não obedecia aos novos padrões do show biz). Antes de fechar a roda, que é muito ampla, não poderíamos deixar de citar a nova Tate — tudo 
indica que a discreta Inglaterra também mudou de tom e resolveu acrescentar ao modesto anexo projetado por Stirling, um novo e imenso edifício (na escala mega das coleções, exposições e obras) - a antiga Usina de Energia Elétrica desativada, reciclada a um custo de mais de 200 milhões de dólares, no intuito de transformá-la no maior Museu de Arte Moderna da Europa. Como se vê o modelo Beaubourg ainda está fresco na memória dos empreendedores urbanos.

Portanto, a imagem estratégica de Bilbao está informando, através deste expediente - o Museu Guggenheim - que existe doravante no País Basco uma real vontade de inserção nas redes globais, que sua capital deixou de ser uma cidade-problema e pode vir a ser uma confiável cidade-negócio. De fato, o que se dá mesmo a ver é o próprio emblema da credibilidade, os sinais emitidos por aquele consumado exemplar de maneirismo arquitetônico: materiais ostensivamente calculados para ofuscar pelo brilho high tech; atmosfera de vanguarda sugerida pelos volumes de corte desconstrucionista; ambiência introvertida de uma enclave para os happy few. Um ícone, enfim, do mundo dos integrados, no caso a indispensável janela dos altos serviços culturais se abrindo para o terciário avançado, sem o qual a mencionada vontade elegantemente arrivista de inserção não passaria de um voto piedoso.

Identificação paradoxal, para dizer o menos, pois o reconhecimento externo e interno buscado se daria em torno de um ponto de fuga tanto mais localmente aglutinador, como pretende, quanto mais se apresenta como uma verdadeira marca de extraterritorialidade, indiferentemente implantável em qualquer outro nó da malha global. Por isto mesmo é dita simbólica essa identidade es- trategicamente planejada com os meios altamente persuasivos da cultura arquitetônica da imagem, inflacionada por duas décadas de pós-modernismo. Quanto ao recheio do museu, ficará em grande parte por conta das coleções itinerantes do próprio Guggenheim - outra ocorrência em rede, cuja ressonância cultural local tampouco é relevante, ou melhor, se resume a filas de dobrar esquinas - dupla imagem da afluência que confirma o acerto do investimento nos serviços de alta visibilidade, de preferência em escala monumental. À vista de uma "sonda cultural" como esta (a expressão é de Francesco Indovina ${ }^{60}$ ), uma agência internacional de avaliação de risco concluiria que no País Basco os governantes finalmente resolveram "pensar global para agir local", como manda a boa gramática gerencial.

\section{Lisboa}

Indovina poderia acrescentar que o lançamento daquela sonda - um museu mais chamativo do que o seu acervo adventício - deve ter sido projetada como quem aproveita uma ocasião (rara em tempos de escassez, em geral vista como uma "fatalidade sistêmica") para inclusive por em marcha processos banais de valorização especulativa e consequente expulsão-troca de populações. Estou me referindo a um artigo de 1996 republicado por ocasião da Exposição Mundial de Lisboa (1998), ela mesma ancorada num Grande Evento gerador de um city marketing em escala global. Como se sabe trata-se de um imenso parque temático - algo como um mega-aquário comemo-

60. "Os Grandes Acontecimentos e a Cidade Ocasional", em Lisbon: World expo 98. Projects, Blau, 1996. Sobre a "Euro 98" ver também: Revista Projeto, $\mathrm{n}^{\circ} 223$. Agosto de 1998. 
rativo da expansão marítima do protocapitalismo europeu - na forma de um catálogo ao vivo do star system arquitetônico, aliás deliberadamente temperado por forte representação do país, pois se trata afinal também de promover internacionalmente, nesta vitrine excepcional, os valores emergentes do savoir faire local. Assim, tudo mais ou menos conforme o mesmo paradigma nesta resposta "estratégica" à "sensação de crise" (e no caso de Lisboa então nem se fala, no que concerne a uma espécie de consciência nacional infeliz que remonta a séculos de "fracassomania"...) por meio de um Grande Evento internacional, aliás na sequência de outro, sua promoção à condição de capital cultural europeia em 1994. De acordo portanto com o novo paradigma, um acontecimento planejado para servir de embrião da reconversão urbana de uma vasta zona industrial e portuária de Lisboa. Ao lado das previsíveis variações "espetaculares" em torno dos temas marítimos e derivados, põe-se contudo o seguinte paradoxo: como "fazer cidade" mediante um evento excepcional - no caso uma Exposição, mas poderia ser uma Olimpíada, uma Copa do Mundo, etc. —, por definição destinado tradicionalmente a fazer a "não-cidade". (Num certo sentido estamos novamente confrontados com as efêmeras cidades-feiras..., como pode constatar qualquer turista, dois anos mais tarde, ao visitar Lisboa.)

Por onde se vê que é próprio de um Projeto de Cidade definido por um Plano Estratégico antes de mais nada chamar a atenção sobre si mesmo, nessa espécie de autorreflexão publicitária. Resultante, segundo seus propagandistas, da "vontade identitária de inserção", visto que é nessa vitrine-mostruário de arquitetura de última geração que a cidade aspirante a ocupar um nó estratégico na rede das cidades mundiais se faz reconhecer, enfim iden- tificar por uma marca que se apresente a si mesma como algo a confirmar sua condição ultramoderna: e assim sendo, qualquer megaevento vem a calhar, não importa de que natureza seja - desde que não se perca a “ocasião"...

Conclui-se, pois, que a identidade que todos buscam é a rigor indiferente ao conteúdo sobre o qual se assentará. Assim numa situação como essa, nada se expõe além da própria exposição, como é da natureza tautológica de um processo eternamente concentrado na autocontemplação celebrativa. Quanto à imagem-identidade da capital em promoção, será tanto mais eficaz quanto se limitar a anunciar que afinal Portugal é Portugal.

E é sobre esse aspecto à primeira vista surpreendente - uma identidade vazia, que a bem dizer não identifica nada, quando deveria ser o contrário, ainda mais por alegar se apresentar forrada por matéria cultural e portanto simbólica - que se detém Indovina, no artigo mencionado, para destacar o aparente contrassenso de um Plano Estratégico na origem de uma cidade propriamente "ocasional", como chama tais surtos de renovação, deflagrados quando se aproveita um Grande Evento, em geral valendo-se de "vazios urbanos", como oportunidade para alavancar (com o perdão da má palavra) investimentos. Ao mesmo tempo, é justamente isto que diferencia o caráter gerencial do novo planejamento urbano de que estamos falando desde o início: vive-se à espreita de ocasiões... para fazer negócios! Daí a indiferença do evento ocasional (até de uma calamidade natural pode nascer a "ocasião" para preencher um "vazio urbano", contraprova enfática do caráter formal de um modo de produção que precisa fazer abstração de qualquer conteúdo quando o que está em jogo é um processo de valorização como fim em si mesmo). Esses Grandes Eventos que em princípio demarcam 
um polo de reconhecimento coletivo (e não estou dizendo que não logrem isso, só que num outro registro), perderam qualquer significado intrínseco, a única coisa que realmente importa é saber se estão em condição de movimentar milhares de pessoas e se permitem ou não construir centenas de milhões de metros cúbicos... Soa assim tanto mais absurdo um Plano Estratégico, ancorado num vazio urbano, que vise "reconstruir o sentido da cidade"! Salvo se o sentido da cidade for aquilo que se espera depois da falência das intervenções urbanas dos anos 70, a saber, como observa mais uma vez nosso Autor: o vazio que a Grande Ocasião permitirá preencher (embora continue vazio de sentido) nada mais é do que o terreno propício para os processos bem conhecidos de capitalização das cidades, ou também conhecido como modernização estrito senso. A saber, modernizar não significa inovar socialmente com equidade, mas antes entulhar as cidades com obras que as façam parecer modernas, primeiro passo indispensável para as tornar rentáveis: arquitetura de materiais high tech - a mitologia exigida pelo espaço construído do terciário avançado - cujas fachadas sequer observam uma relação direta com a realidade, pois se trata apenas de tornar visível (e impressionante!) o próprio "imaterial" a que se resumem os serviços de última geração prestados aos comandos ou subcomandos das redes empresariais. Digamos que o "cultural" é a expressão multiforme dessa mitologia da nova fronteira tecnológica e social transposta pela Information Age.

\section{Berlim}

Guardadas as diferenças, algo semelhante se passa atualmente em Berlim, (embora o Grande Evento pareça ser bem menos efêmero: a transferência de uma capital).
As proporções são evidentemente outras - superlativas. $^{61}$ Ao menos do ponto de vista quantitativo, não há dúvida de que nada no mundo se equipara à reconversão de Berlim "reconquistada". Mais de trezentos escritórios de todo o mundo foram mobilizados, com destaque, obviamente, para o referido star system: dos complexos multifuncionais da Postdamer Platz - Sony e Daimler-Benz, sob o comando de Murphey/Jahn, Rogers/Piano e outros mais, entre os quais estão sempre alguns escritórios alemães, sendo um dos mais presentes o do arquiteto Kollhoff (aliás em Berlim, há quem fale no poder da "máfia" dos arquitetos, associados, obviamente, às empresas, a ponto de já terem passado para o noticiário policial) ${ }^{62}$ - aos museus, embaixadas, escritórios, grandes magazines, prédios administrativos, cá e lá residências: tudo aí projetado para simbolizar não apenas a Alemanha unificada, com o patrocínio do Estado e da Municipalidade, mas o mundo do capitalismo globalizado e triunfante (ou, no mínimo, a maior potência da União Europeia), transformando a antiga capital do Reich no maior show-room de arquitetura

61. Inclusive se levada em conta a iniciativa da própria prefeitura de Berlim pouco antes da unificação, projetada para o aniversário da cidade, em 1987, na forma de uma grande exposição de arquitetura, que foi o IBA (Internationale Bauausstellung Berlin), e que, de forma inédita, havia trazido os maiores e mais variados nomes da arquitetura mundial para projetar edifícios - no mais das vezes conjuntos residenciais - nas áreas abandonadas ou pouco habitadas depois da guerra (sem falar na restauração de Kreuzberg, até aquela década abandonado e, em sua maioria, squaterizado, logo, aliás, devidamente gentrificado).

62. Veja-se sobre o "cartel" dos arquitetos e outros bastidores: Eva Schweitzer, Grossbaustelle Berlin, wie die Haupstadt verplant Berlin, Berlim: Ullstein, 1998 (que me foi indicado e parcialmente traduzido pela arquiteta Beatriz Kara José). Ainda sobre a arquitetura berlinense, ver o catálogo:. Neue Architektur. New Architecture - Berlin 1990-2000, Berlim: jovis, 1998. Mais detalhes o leitor pode encontrar num texto posterior meu, de 2004, e reproduzido em Berlim, Barcelona, duas imagnes estratégicas, cit. 
deste final de século (segundo alguns, menos entusiastas, um verdadeiro bricabraque) e o símbolo mais enfático da liderança alemã (pelo menos europeia). Como não poderiam faltar as velhas tradições berlinenses, reconstroem-se os velhos edifícios da Pariser Platz, mantém-se o desenho urbano e, na medida da possível, restringem-se os gabaritos. Estranha combinação de ousadia e autoritarismo, numa reforma que, apesar de tudo, vem sendo criticada como extremamente conservadora! Irritado, Rogers reclamou que era impossível projetar para Berlim que não fosse um prédio quadrado, mas nem por isto deixou de construir um caixote-colagem-mostruário das soluções adotadas em outros projetos seus. (Apesar da disputa de alguns arquitetos e empreiteiras com a administração, ninguém quer ficar de fora).

Nesse contexto, não se poderia imaginar melhor lugar de onde observar a cidade do que, nada mais nada menos, a cúpula do Reichstag, entre as duas Berlim — um imenso domo de vidro sobre uma estrutura metálica projetada por um dos astros mais festejados da arquitetura high tech (afinal a Alemanha é a frente avançada da tecnologia europeia), Norman Foster (só que um inglês...). Na verdade, ainda uma vez um híbrido: a tradicional arquitetura neoclássica (de Wallot), que domina a cidade desde Schinkel, combinada à arquitetura de ponta, internacional. Ao mesmo tempo, também, fazendo convergir o exterior e o interior do edifício, o parlamento, reunido por detrás das paredes do velho prédio pode ser visto do alto através de um teto de vidro. Transparência da democracia, oferecida em espetáculo aos olhos do visitante embasbacado. Não é por acaso também que a única área verticalizada - projetada para vir a ser a Manhattan da Nova Capital - seja justamente a região central da anti- ga cidade do leste. Enfim, o previsível clichê (nada como a reiteração para vender): a meio caminho entre o Leste e o Oeste, Berlim reposta no epicentro da Europa, e do mundo, no subtexto. ${ }^{63}$

E, no foco de tudo, a cultura ${ }^{64}$ : do patrimônio restaurado, com destaque para a ilha dos museus, ao esforço em reativar os lugares mais representativos da Berlim dos estereotipados anos 20, como Postdamer Platz, Prenzlauer Berg, no leste, que volta a ser o bairro da boêmia artística, ou o velho Mitte, resultado da emigração de muitos dos jovens artistas, em especial os que viviam em habitações squaterizadas de Kreutzberg oeste, agora elevados à categoria de galeristas, estimulados pelos subsídios do governo. ${ }^{65}$ Além do mais, confirmando que o que se cultua na imagem promocional de uma cidade é ela mesma, a Bienal de Berlim, ao se renovar inteiramente, adotou como tema a própria Berlim ("Berlim/Berlim") $\mathbf{6 6}^{\mathbf{6}}$ — de modo que o visitante não perdesse de vista que o que está em jogo é a nova cap. à procura de sua identidade (universal...). Tão oca quanto o domo, e incontestável quanto a certeza de que A é igual A.

Como no caso de Paris, não há estritamente falando, nenhum Plano Estratégico por detrás da renovação de Ber-

63. Sobre isto ver o artigo do Senador para o Desenvolvimento, Peter Strieder, "Berlin, City of the future?", em Stadforum, n³6, junho de 1999.

64. Como se pode ler num artigo do insuspeito Vargas Llosa, a antiga capital do Reich vai se transformando "na maior empresa (sic) arquitetônica e urbanística de que se tem memória", informando que para elevá-la ao status simbólico de capital da União Monetária Europeia, "a menina dos olhos de tal promoção (sic) foi a cultura". "Cidade de Todos", in O Estado de São Paulo, 11.10.98.

65. Devo em parte estas informações sobre Berlim à arquiteta Beatriz Kara José. (Voltei à Berlim após a publicação deste ensaio, ao final de 2000 - o que me levou a escrever o texto citado acima, nota 59.)

66. Cf. Berlin!Berlin!, de Marius Babbias e Beatrice von Bismark (org.), Taschenbuch, 1998. 
lim (ao menos nos termos do receituário catalão). E, no entanto, a fórmula é a mesma em todos os casos em evidência até aqui, qualquer que seja o nome de ocasião que se lhe dê. Não falta nenhum dos ingredientes do atual modo de fazer cidade, além do mais na escala gigantesca de uma capital com ambições imperiais: megaprojetos emblemáticos; urbanismo acintosamente corporativo, nenhuma grande marca global está ausente; gentrificações se alastrando por todo o canto; exibição arquitetônica em grande estilo; parques museográficos; salas de espetáculo agrupadas em complexos multiservice de aparato e muita, muita animação cultural 24 horas. Ou seja, continuamos na mesma.

\section{Conclusão: contaminações fatais}

Tudo isso dito, recapitulo em duas palavras a singular comédia ideológica a que estamos assistindo. De um lado, urbanistas e arquitetos - na maioria dos casos, de clara ascendência progressista - projetando em termos gerenciais acintosamente explícitos, aliás apresentados como garantia da consistência do projeto, o que paradoxalmente lhe acrescenta um charme suplementar. De outro, o espetáculo surrealista oferecido por empresários e banqueiros enaltecendo, como nos bons tempos do contextualismo que se imaginava sinceramente dissidente, o "pulsar de cada rua, praça ou fragmento urbano". Como se trata estrategicamente de uma parceria completa, não surpreende que também tenham se tornado todos parceiros no mesmo jargão da autenticidade urbana, que se poderia chamar, como sugerido, culturalismo de mercado. Como pudemos chegar a este ponto? É verdade que o momento é de ofuscamento generalizado e que se costuma aludir, a título de explicação sociológica, a uma reviravolta cultural em favor do mercado.

Digamos que a glamourização da economia de mercado, a ponto de se falar, com a desfaçatez dos vencedores, na Ética como fator de produção, acaba convergindo com a crítica cultural à matriz produtivista da fase anterior, Movimento Moderno inclusive, de tal modo que a fluidez alegada pelo novo paradigma da comunicação está cada vez mais parecida com a novíssima flexibilidade requerida pelo mundo produtivo dos grandes negócios, que não por acaso se organizam em redes comunicacionais. Para encurtar: deu-se o que estamos vendo, algo como um pensamento único das cidades ${ }^{67}$ - em que se casam o interesse econômico da cultura e as alegações culturais do comando econômico - que ronda as cidades em competição pelo financiamento escasso no sistema mundial, e por isso mesmo compartilhado à revelia das preferências político-ideológicas dos administradores de turno. Num universo tão unidimensional assim, por certo não ocorrerá a ninguém considerar uma aberração histórica o programa suicida do capitalismo global.
67. Venho recorrendo a esta fórmula um tanto esdrúxula desde minha comunicação no Simpósio de 1998, referido em nota na abertura deste capítulo. Na ocasião procurava sugerir com ela algo como uma matriz conceitual comum na origem das novas estratégias urbanas. Fórmula que afinal acabou servindo de título para o livro escrito em parceria com Carlos Veiner e Ermínia Maricato e editado pela Vozes. 


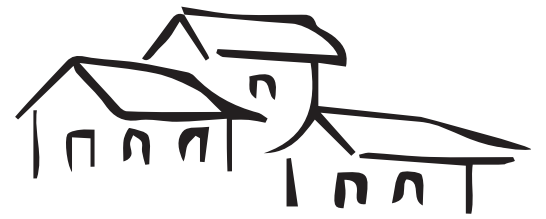

Este livro foi composto nas fontes Literata e Work Sans em Junho de 2021. 